\title{
THE SUSTAINABLE TOURISM DEVELOPMENT IN THE NORTHERN COASTAL AREA OF SAUDI ARABIA (CASE STUDY: COASTAL CITIES IN TABOUK REGION)
}

\author{
Abd El-Aziz Bin-Naser Al-Dosery \\ Associate Prof. of Arch. Planning, Faculty of Arch. And Planning, \\ King Saud University, Kingdom of Saudi Arabia
}

(Received June 24, 2007 Accepted July 11, 2007)

The objective of this research is to set up a strategic vision and a sustainable tourism development plan for the northern coastal area of the red sea in Tabouk region, northwest of Saudi Arabia, in light of National Spatial Strategy (NSS) and National Tourism Strategy considering natural and environmental resources in Tabouk region, for a balanced urban development environmentally, economically, and socially.

This research will examine the potential natural, environmental and cultural resources in the coastal area of Tabouk region by applying the descriptive approach and analyzing the surveys and interviews and data collection results. The study area is located within the administration boundary of Tabouk region in northwest part of Saudi Arabia, covering over $500 \mathrm{~km}$ of coastal line starting from Hagel in the north of Al aqaba Gulf and ending in the south of Umlej city on the red sea. The findings in this research reveal the importance of the tourism resources in the coastal areas of Tabouk region.

The study concludes that the coastal areas of Tabouk region has some of the most significant and promising areas with the ultimate potentiality for sustainable tourism development at saudi Arabia.

KEYWORDS: sustainable tourism development tourism development coastal development red Sea.

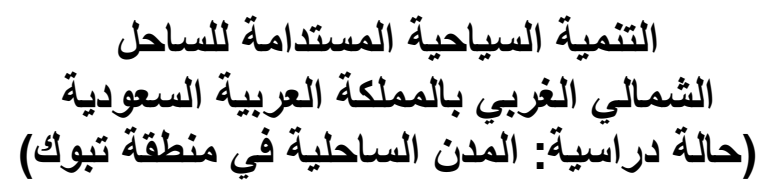

$$
\text { د./ عبد العزيز بن ناصر الدوسـري }
$$

أستاذ مساعد ورئيس قسم التخطيط العمراني كلية العمارة والتخطيط ـ جامعة التئة الملك سعود المملكة

العزبية السعودية العية العمارة

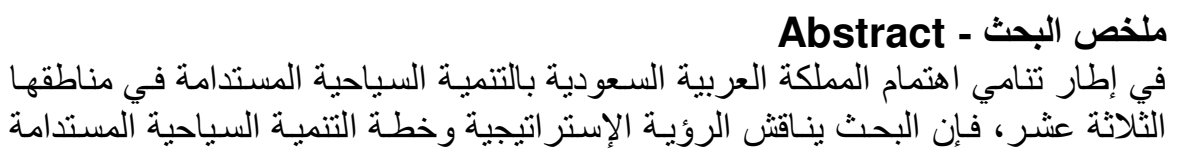


للساحل الثمالي الغربي للمملكة العربية السعودية، بمـا يتمشى مـع خطط التنميـة الوطنيـة

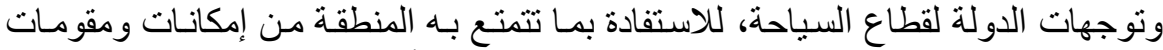

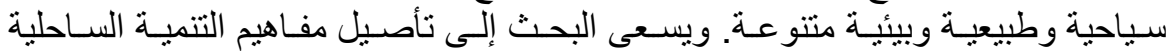

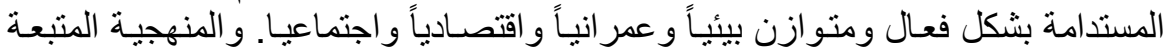

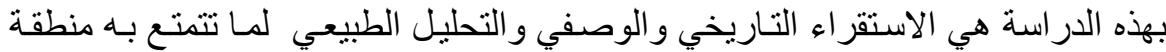

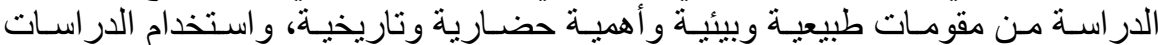

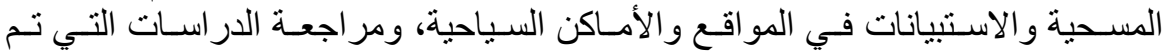

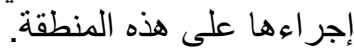

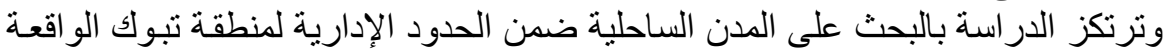

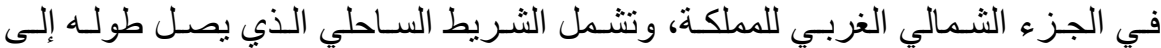

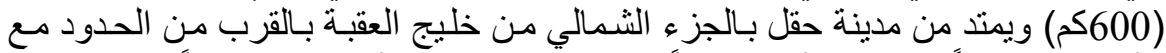

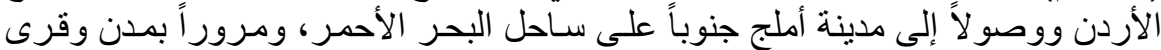

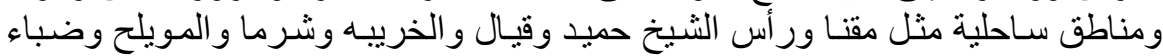

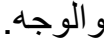

وقد أوضهت الدراسات التحليليـة للمدن عن توفر كم هائل من المقومـات السياحية التي

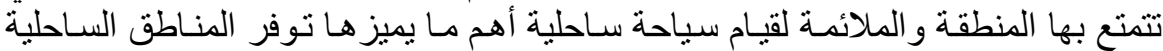

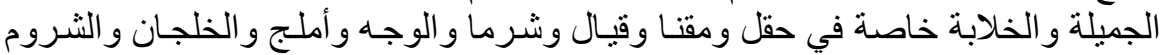

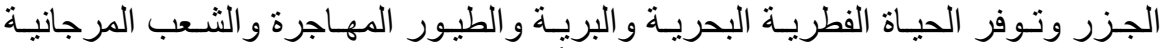
المميزة واعتدال المناخ و الرطوبة الربة النسبية صبيفاً.

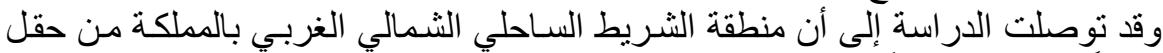

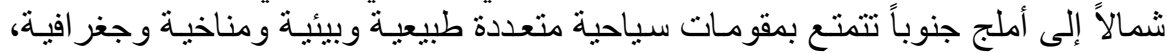

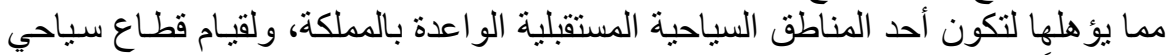

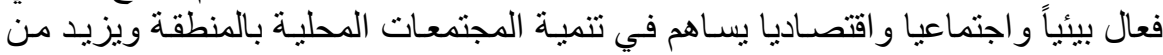
مساهمة المنطقة بمستويات الناتج الوطني للمملكة السعودية.

\section{الكلمات الأسساسية في البحث: البمثة:

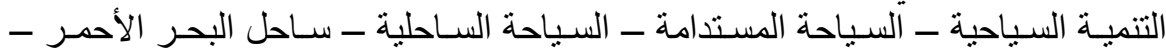

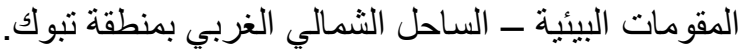

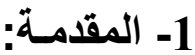

عندما تكون السياحة حديثة في مجتمع محلي تقليدي فأنها نواجه سلسلة من الصعوبات في العمل

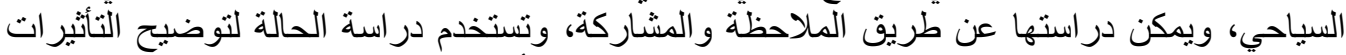

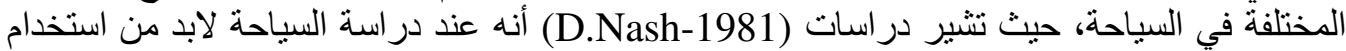

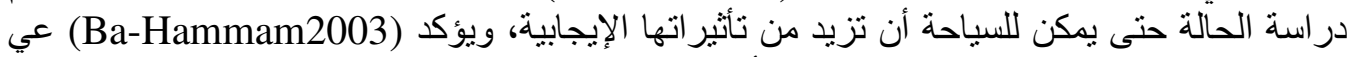
ضرورة المقابلات الثخصية و الملاحظات، كأساس للتخطيط السياحي واستخلاص التهات النتائج الو اقعية.

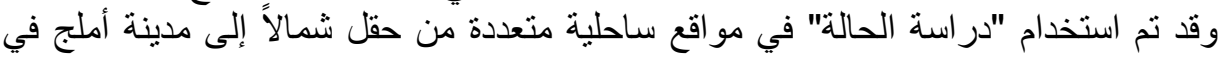

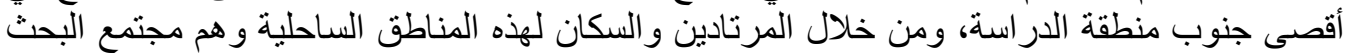

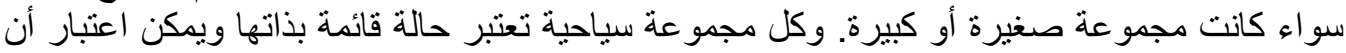

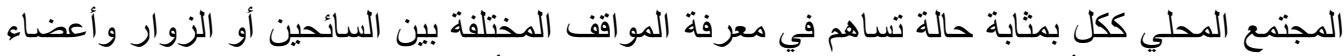

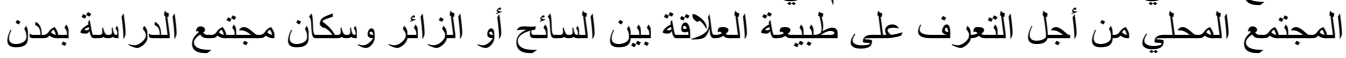
وقرى الساحل الثنمالي الغربي للمدلكة. 


\section{1-1 أهمية منطقة تبوك في إطارها الإقليمي:}

و تعتبر منطقة تبوك من المناطق الهامة بالمملكة العربية السعودية، من حيث أهمية موقعها الاستر اتيجي

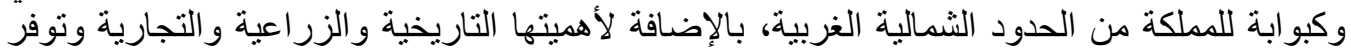

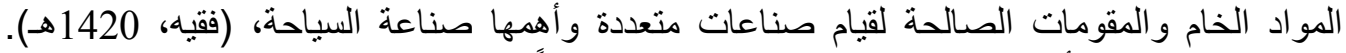

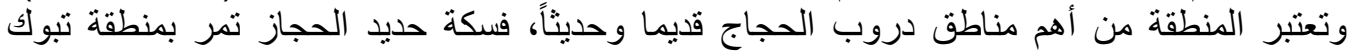

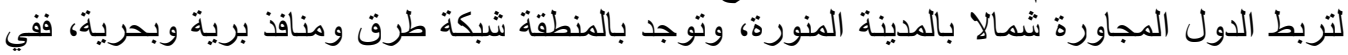

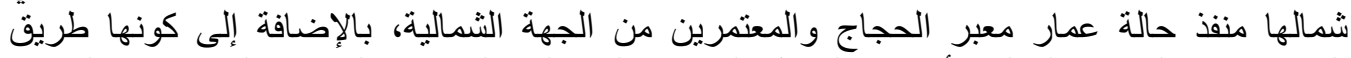

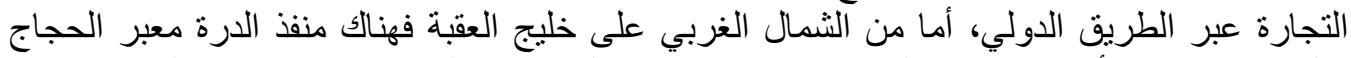

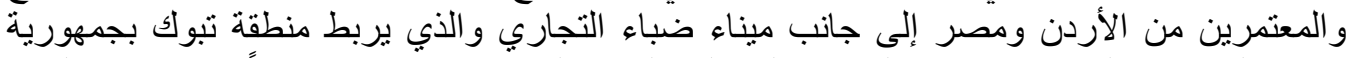

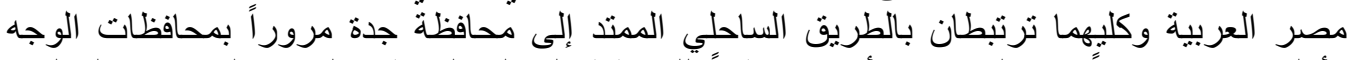

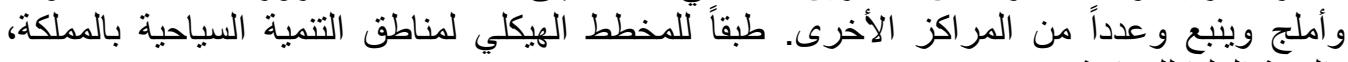
(الهيئة العليا للسياحة - 2001 201 مندم).

\section{2-1 مؤشرات الوضع الراهن لمنطقة تبوك:}

وقد حظيت المنطقة بمجالات التطور والتنمية الثاملة لجميع محافظاتها، مما أدى إلى ازدهار المنطقة

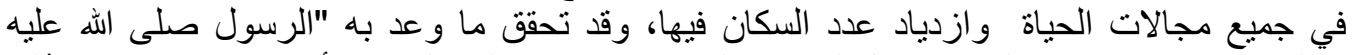

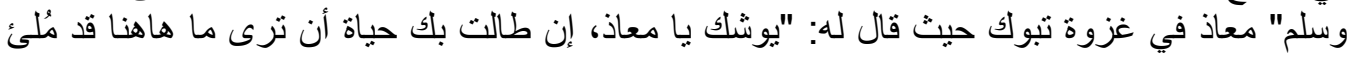

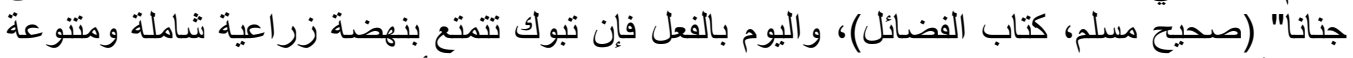

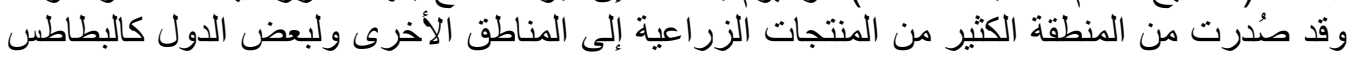

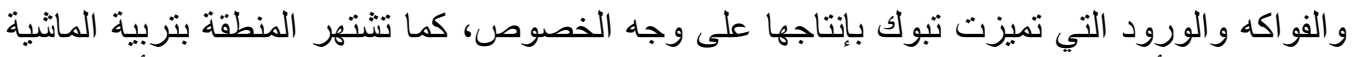

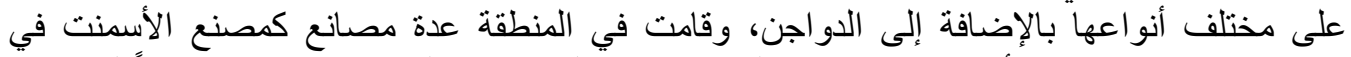

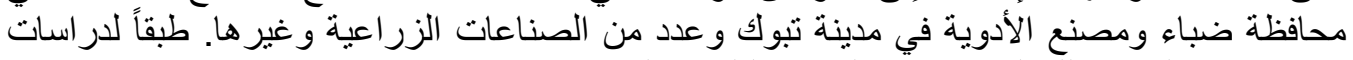

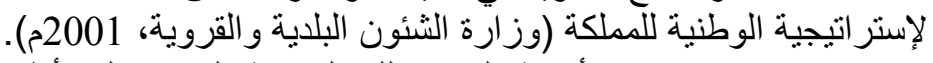

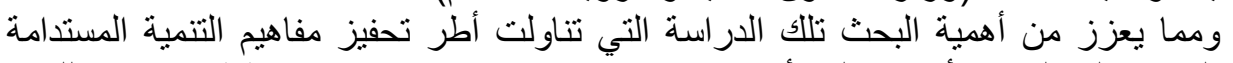

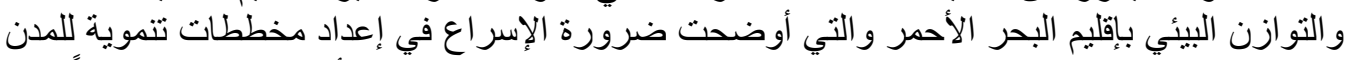

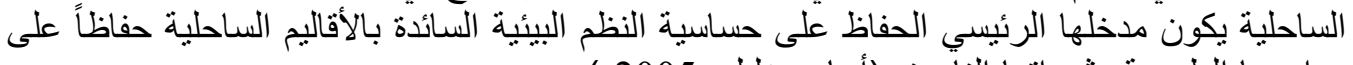

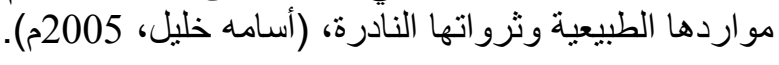

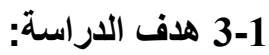

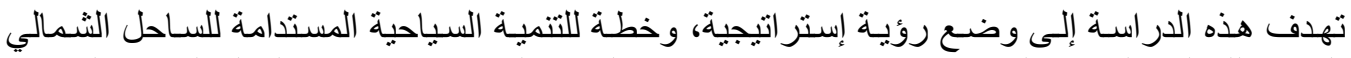

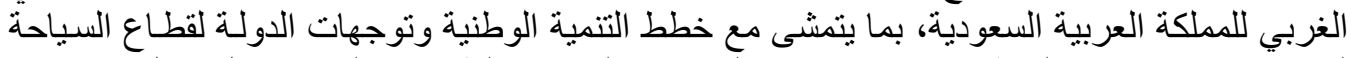

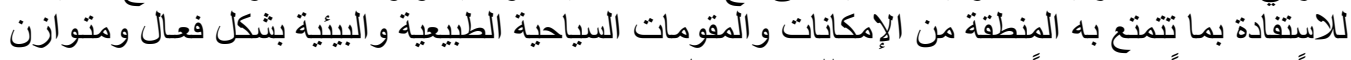

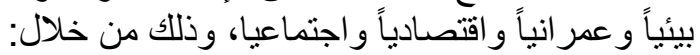

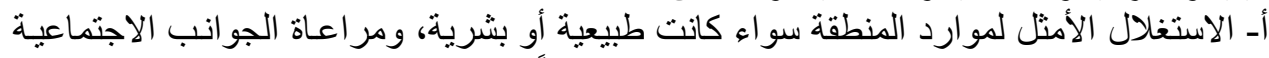

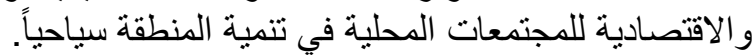

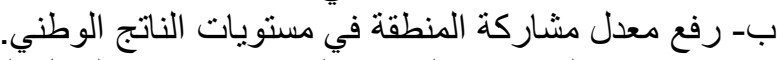

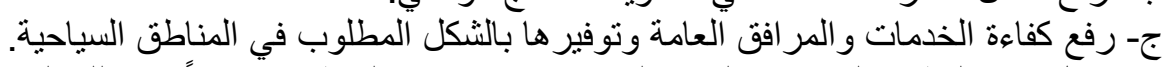

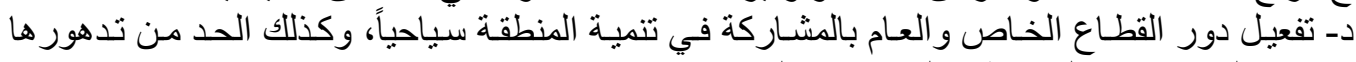

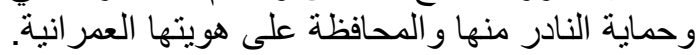
هـ- ربط مناطق الجذب السياحي بوسائل وشبكات النقل، وكذللك رفع كفاءة شبكة الطرق الر الهنة. 


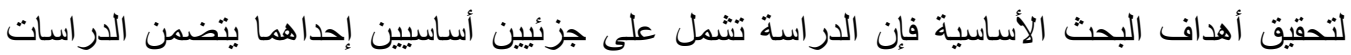

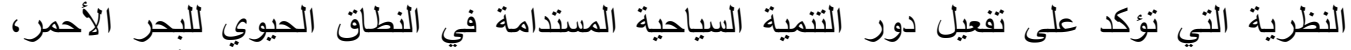

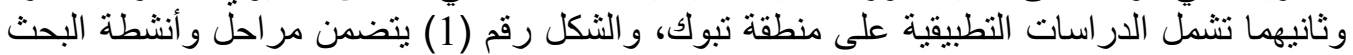

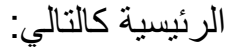

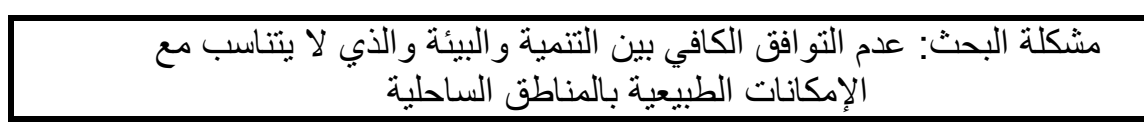

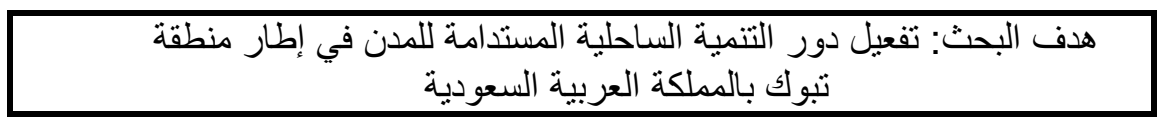

\begin{tabular}{|c|c|}
\hline ثانياً: تطبيقـات البحث: & أولاً: الإطار النظري للبحث: \\
\hline 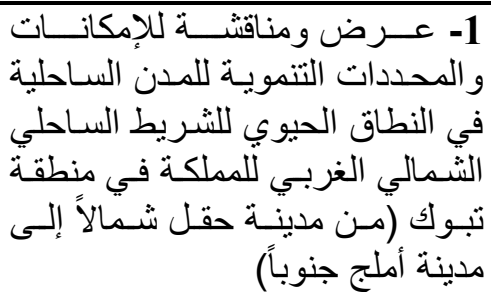 & 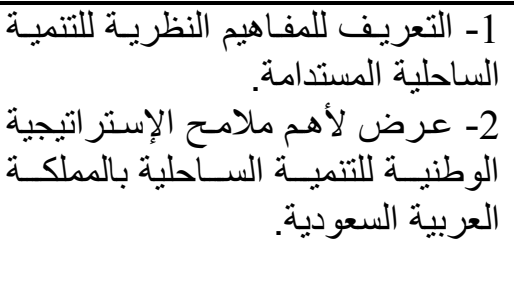 \\
\hline * * أهم المقومـات و المحـددات للتنميـة & معايير التنمية الساحلية المستدامة. \\
\hline
\end{tabular}

نتائج البحث: الموجهات الإستراتيجية للتنمية الساحلية المستدامة لمنطقة تبوك

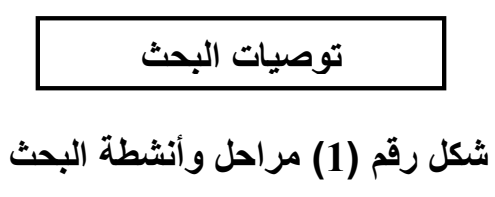

2- الأطر النظرية للتنمية السياحية المستدامة:

أصبح مفهوم السياحة المستدامة (Sustainable Tourism) مفهوم هام جدا في التنمية السياحية،

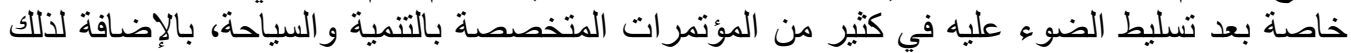

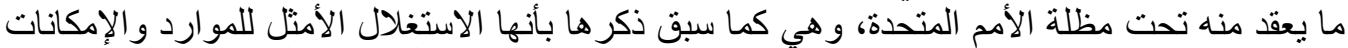

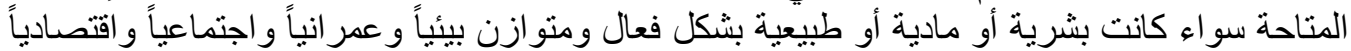

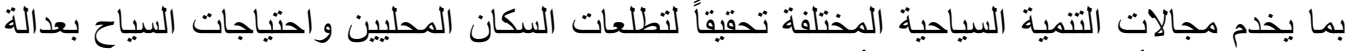

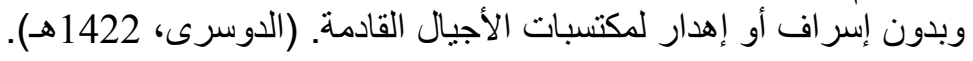

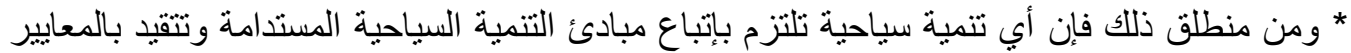

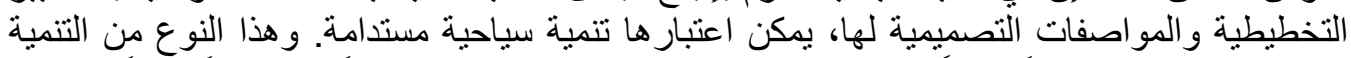

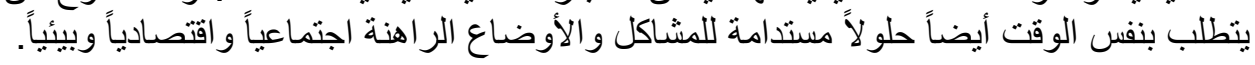
1-2 1- السياحة من المنظور البيئي: 
يشهد المجال السياحي تنامي في نوعية السياحة والتي تعتمد على الطبيعة، بالإضافة إلى النوعيات

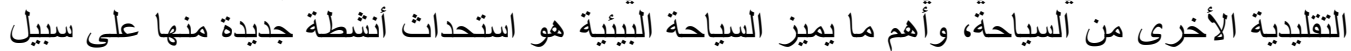

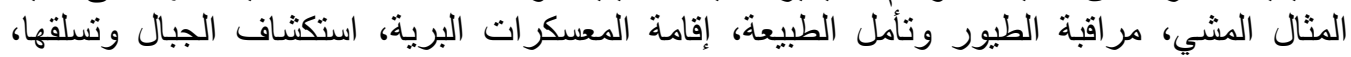

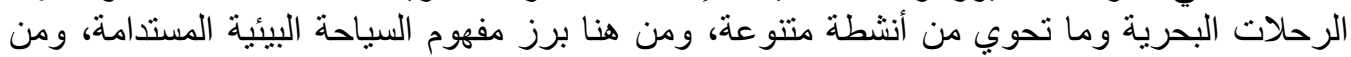
و اقع بيانات منظمة السياحة العالمية (WTO عام 1999م) فإن الطية الطلب على على السياحة البيئية و الرحلات

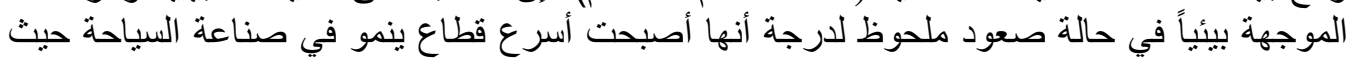

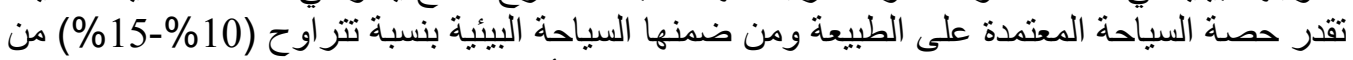

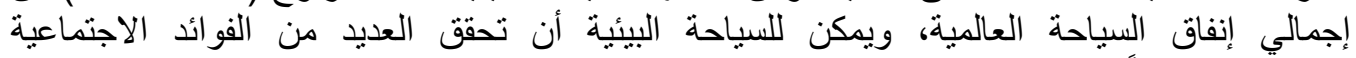

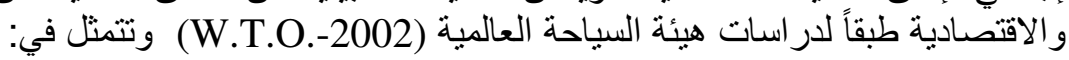

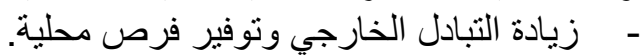

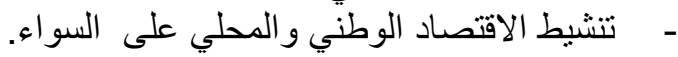
- رفع مستوى الاهنمام بالّوعي و التعليم البيئي.

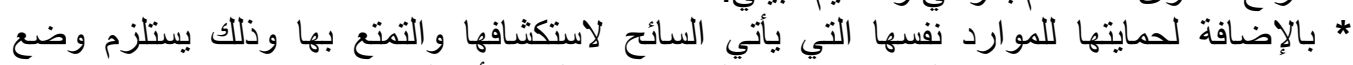

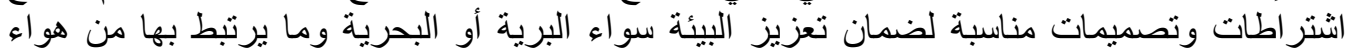

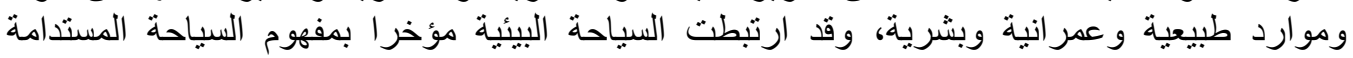
و التي تستند على مفهوم حماية البيئة و الموارد للوقت الئن الحالي دون الإخلال بالطلب عليها مستقبلاً.

\section{2-2 بالسياحة في البيئات البحرية:}

تشكل البيئات البحرية عاملاً ومورداً هاماً في السياحة، نتبع من عدة عناصر كما ورد في دراسات الغيص - 1999م، و هذه العناصر كالتالي: - وجود تنوع بيولوجي أحيائي داخل البيئات البحرية، وخاصة الغئ الغير ملوثه فنجد بها كائنات بحرية

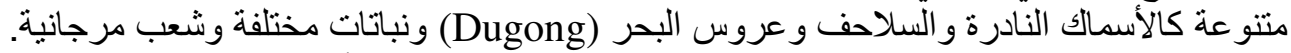

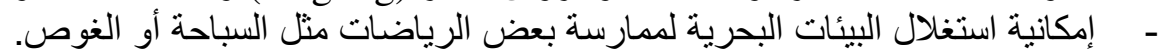

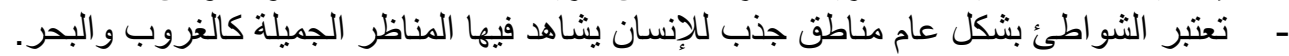

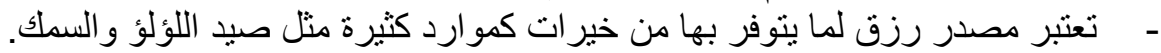

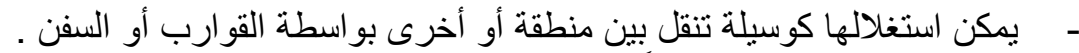

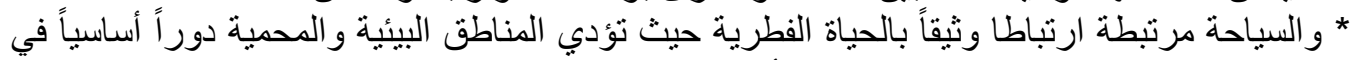

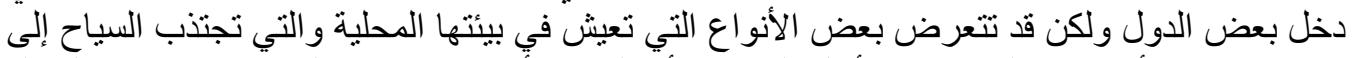

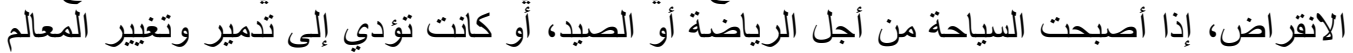

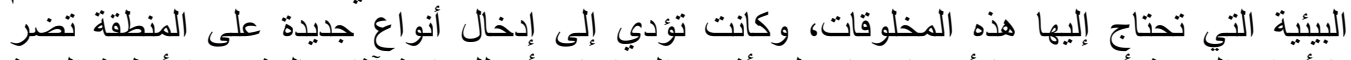

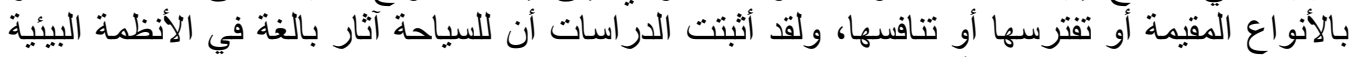

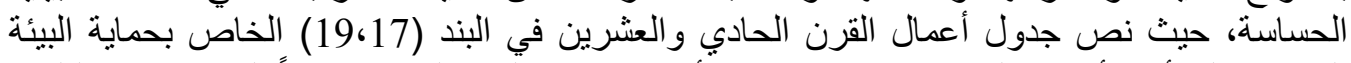

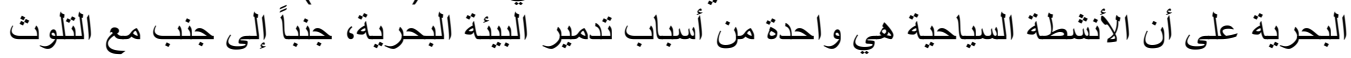

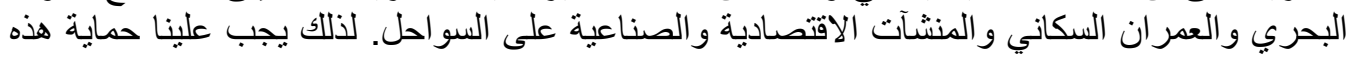

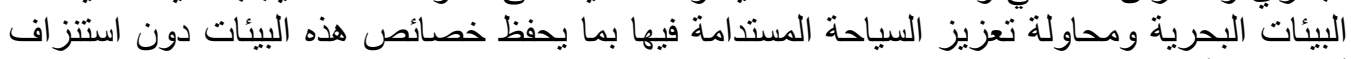

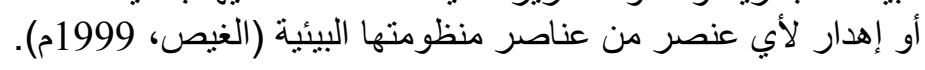

\section{3-2 أطر تحقيق التنمية السياحية المستدامة:}

لتحقيق التنمية السياحية المستدامة لابد أن تتضافر الجهود المختلفة سواء بالقطاع الحكومي أو الخاص

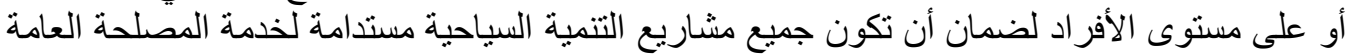

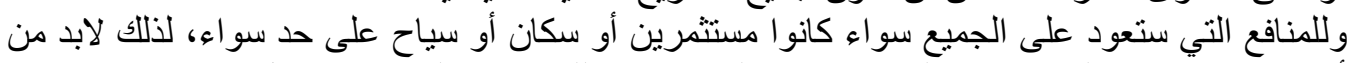

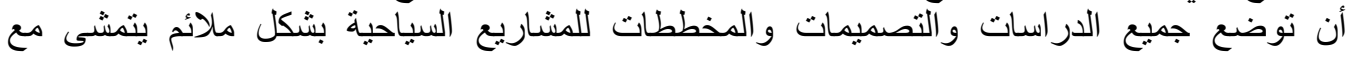




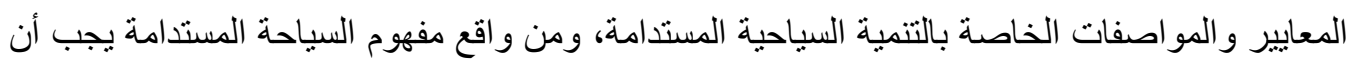
تتوفر في التتمية السياحية المستدامة مجموعة من العناصر كما ورد في تقارير منظمة السية السياحة العالمية

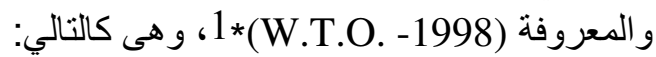

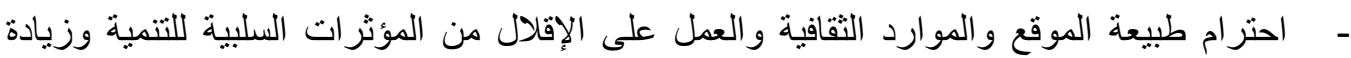
العوامل الإيجابية، والاستجابة البيئية الملائمة.

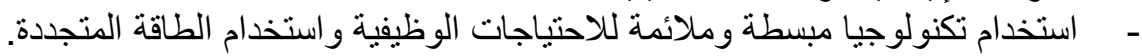

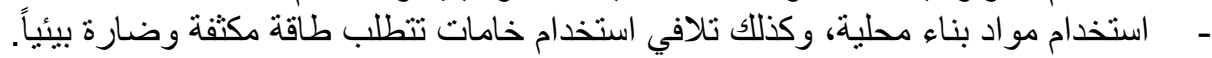
- استخدام مرونة الفراغ بشكل مثالي لتلإقلال من حجم المباني وما يتبعها وكذلك استخدام الموارد

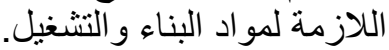
- القيام بالتعديلات والتوسعات المستقلية بشكل يحد من اللجوء لعمليات الهدم والإزالة مما ينتج

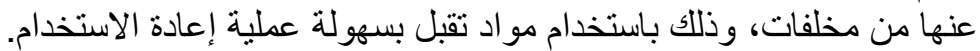

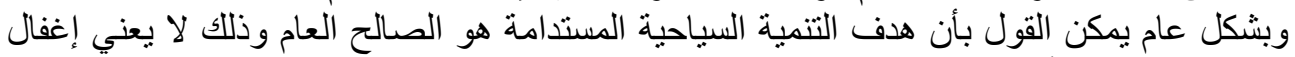
المردود المادي للأفر اد و القطاع الخاص.

\section{4-2 المعايير الخاصة بالتنمية السياحة المستدامة:}

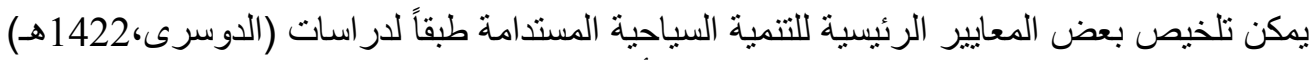

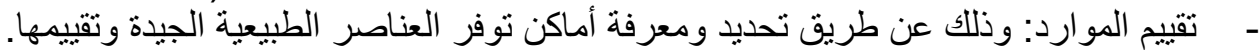

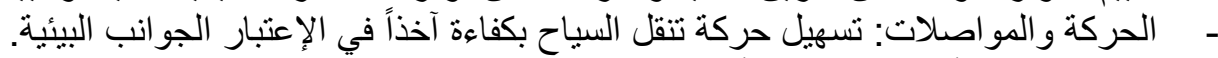

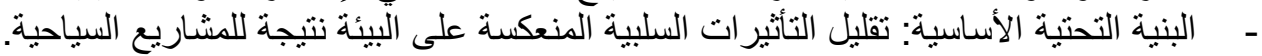

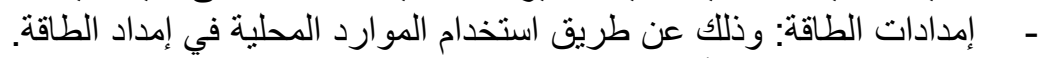

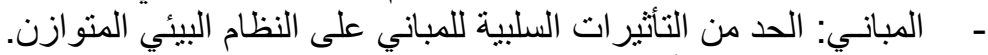

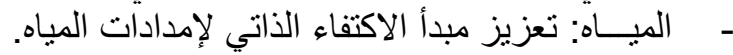

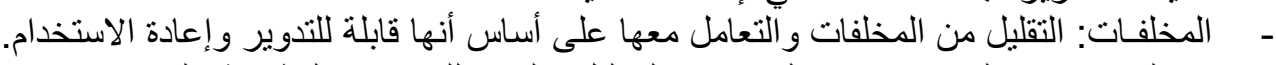

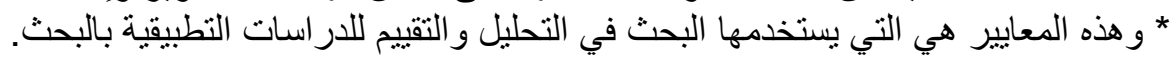

\section{3- الخطط والاستراتيجيات المؤثرة على التنمية الساحلية الإقليمية لمنطقة تبوك:}

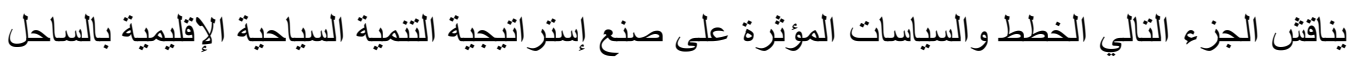

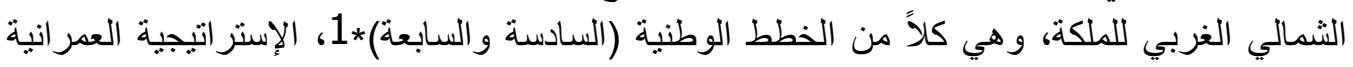
الوطنية، استر اتيجيات تتمية المناطق، و الخطة الونة الوطنية الهيكلية للسياحة.

\section{1-3 الخطة الوطنية الهيكلية للسياحة:}

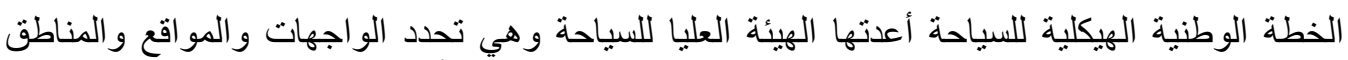

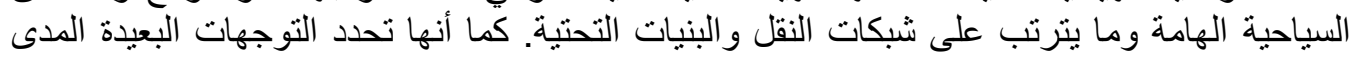

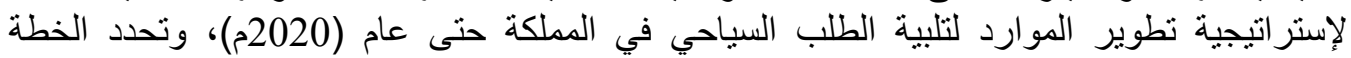

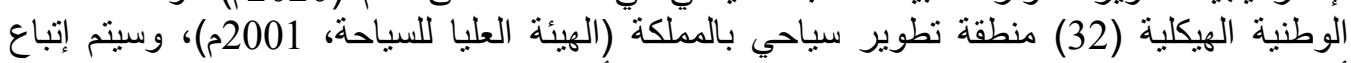

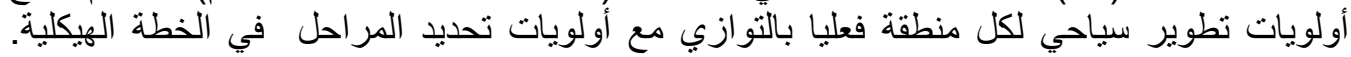

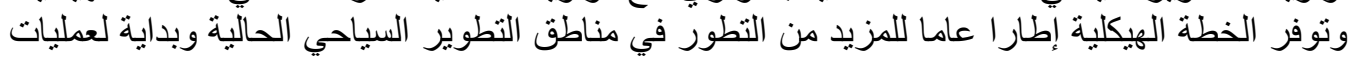

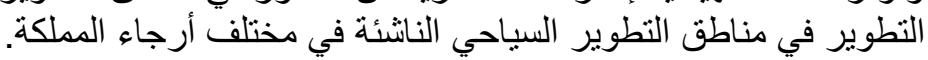
2-3 سياسات الخطة الوطنية الهيكلية للسياحة:

\section{1* World Tourism Organization.}


- الترويج للتطوير السياحي المتوازن في المناطق و الأقاليم وفقا لخصائص وأنواع الموارد السياحية

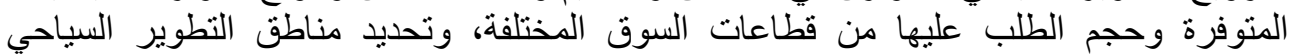

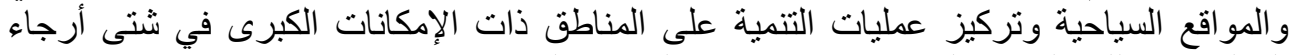
المملكة، وكذللك الترويج للاستثمار في مناطق التطوير التير السياحي وحمايته.

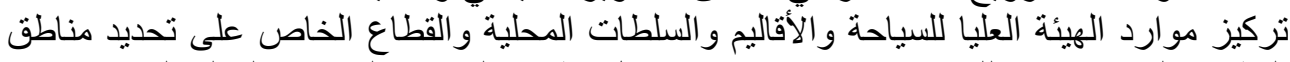

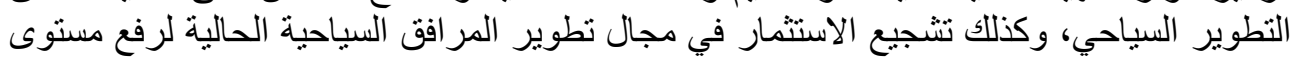

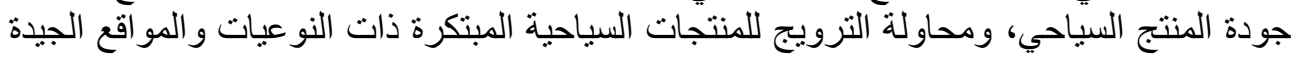

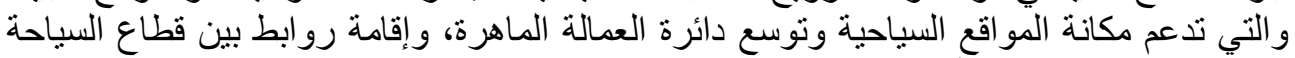

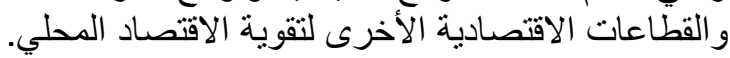

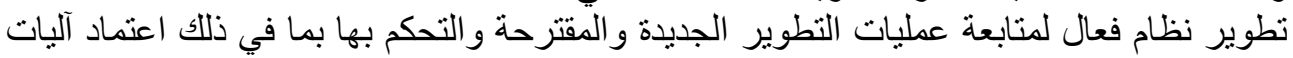
إثراك الجهات الحكومية ذات الصلة وشركاء الهيئة في عمليات صنع القرار آت ونقلة فئها إلى حيز التنفيذ.

تحديث الخطط السياحية على نحو منتظم مع أخذ معدلات الطلب الحقيقية والمتوقعة في الاعتبار

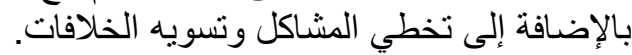

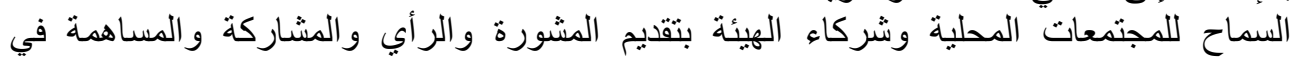

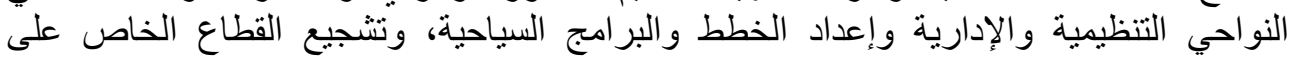

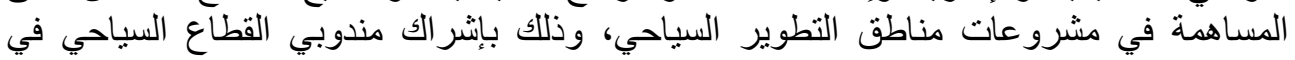

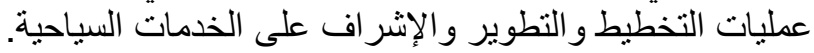

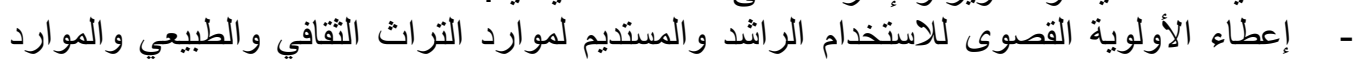

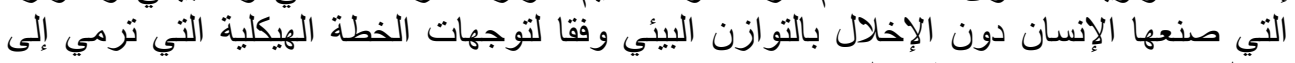
تكامل عناصر ومكونات قطاع الإن السياحة.

2-3 أولويات التطوير السياحي للنطاق الساحلي لمنطقة تبوك:

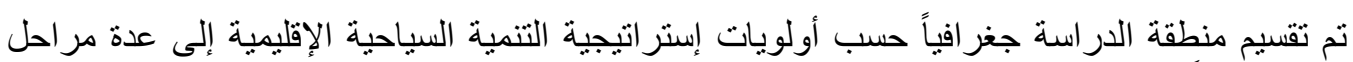

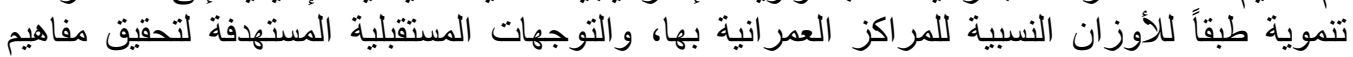

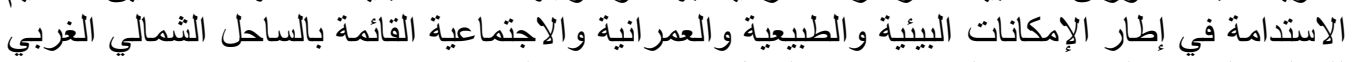

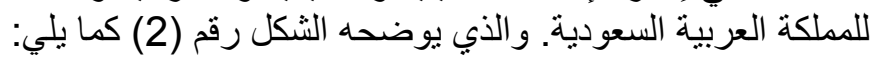

*1 تقسيم مرحلي للخطط التنموية التي وضعتها وزارة الثئون البلدية والقروية لتنفيذ توجهات الإستر اتيجية الوطنية للمملكة عام 1421 هـ. 


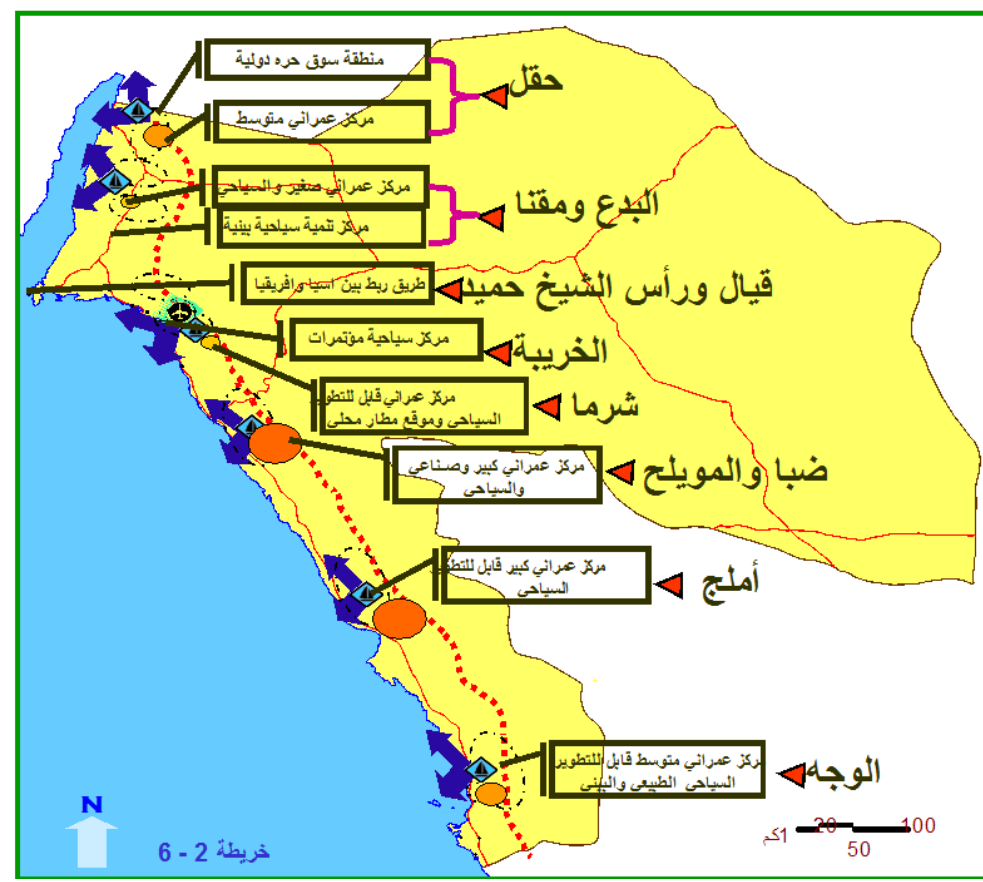

شكل (2) توجهات إستر اتيجية

التنمية السياحية الإقليمية بالساحل الثمالي الغربي للمملكة

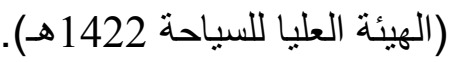

* المرحلة الأولى للتنمية السياحية: وتشمل مدينة الوجه و المناطق الساحلية شمالها وجنوبها، بما فيها

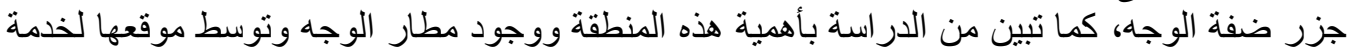

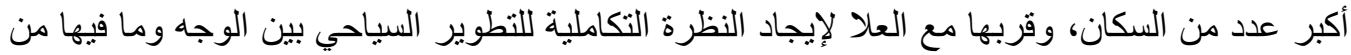

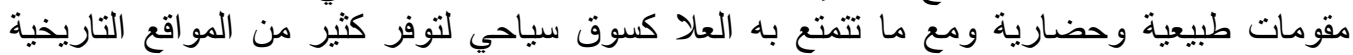

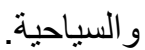

جزر ضفة الوجه كمنطقة سياحة بيئية، ويمكن أن ينم إنشاء منتجع سياحي (نزل بيئي (Ecolodge)

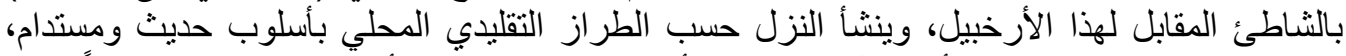

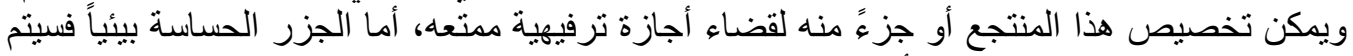

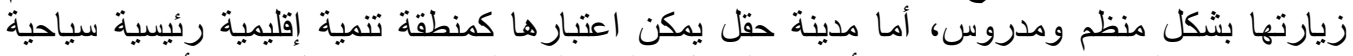

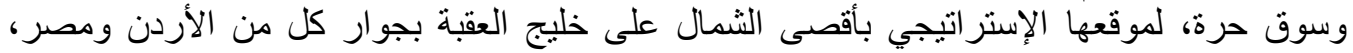

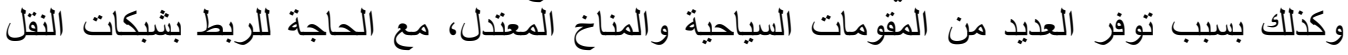
و المو اصلات و إنشاء مطار محلي لخدمنها.

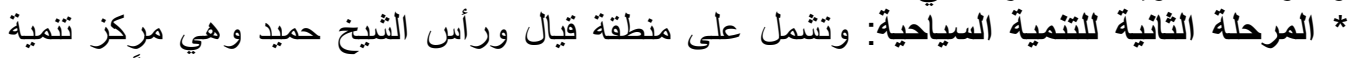
إقليمي رئيسي (سياحي-تجاري)، مع إمكانية عمل سياحة بيئية في المئية المناطق الحساسية الحسية بيئياً في قيال

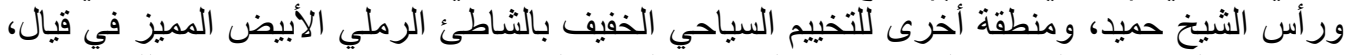

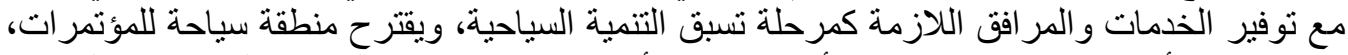
و هي منتجع أو عدة منتجعات سياحية أحداها يمكن أن يخصص كمنتجع لسياحة المؤتمرات الرسئة للرسية 
تتبناها الدولة، ومن المواقع المقترحة لذلك ساحل شرما والخريبه أو المنطقة الواقعة بينهما، لوجود

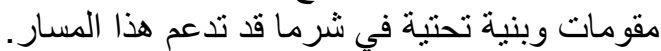

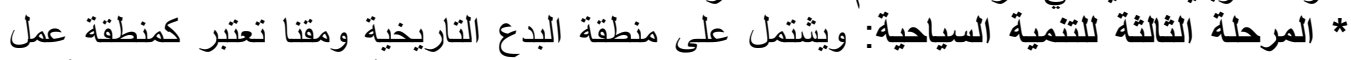

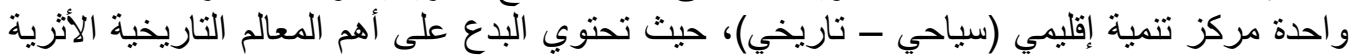

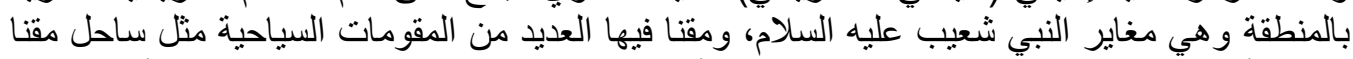

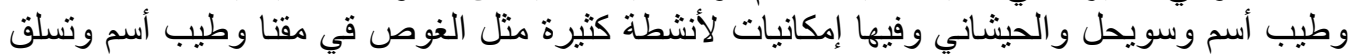
الجبال في سويحل وجبل طيب أسم وركوب الأمواج بمقنا وغيرها من من الأنشطة السياحية. مراكز

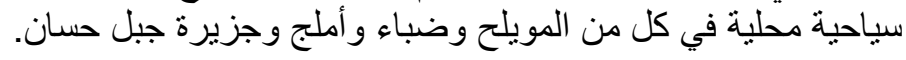

\section{4-3 التوجهات الأساسية للتنمية الساحلية لمنطقة تبولك:}

لابد للتنمية السياحية من التكامل والتنسيق مع القطاعات التنموية المرتبطة بها، كالتنمية العمرانية

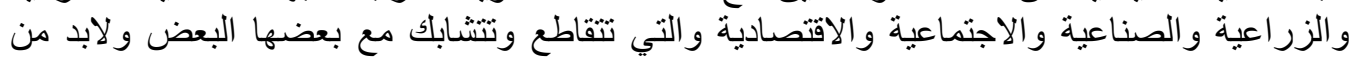

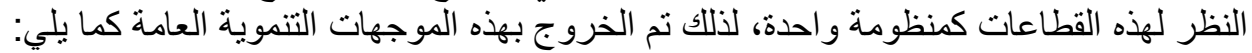

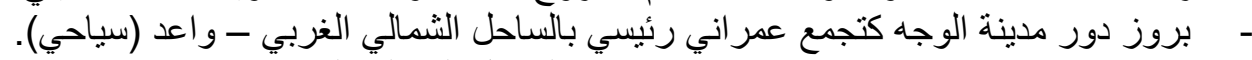

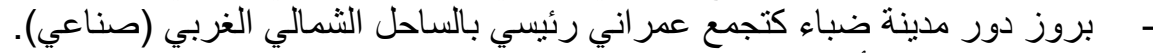

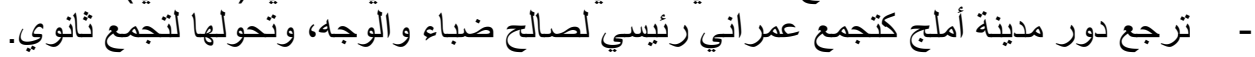

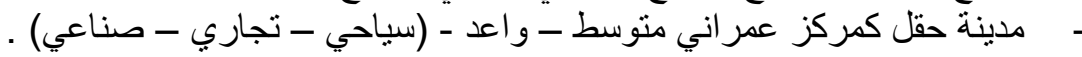

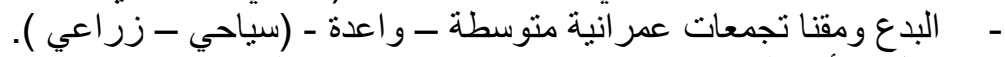

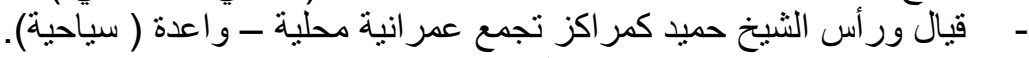

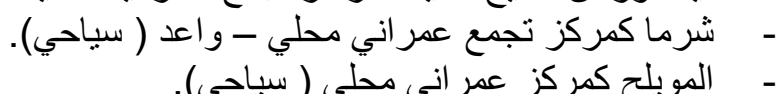

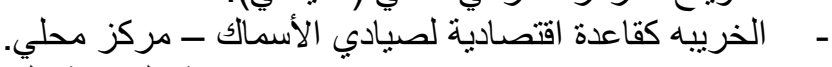

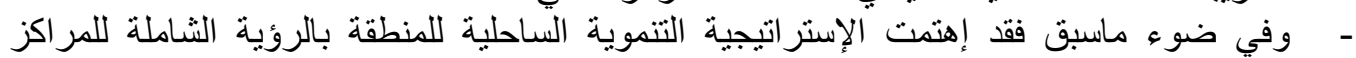

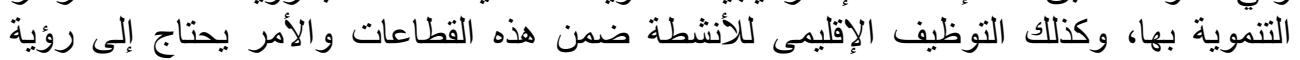

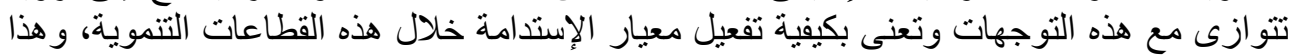

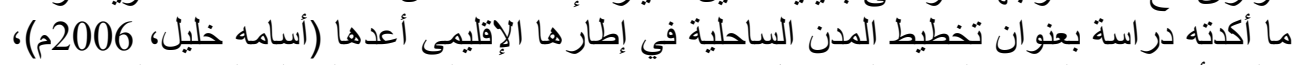

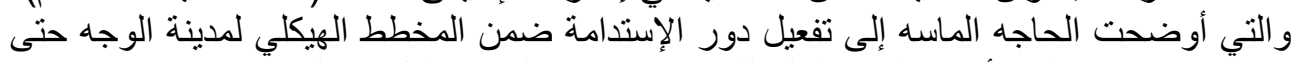

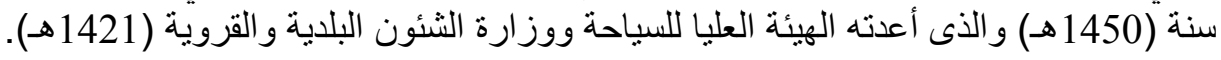

\section{4- دراسات تطبيقية على الساحل الثمالي الغربي للمملكة العربية السعودية:}

- تقع منطقة تبوك شكل (3) في الجزء الشمالي الغربي من المملكة العربية السعودية ما بين جبلي

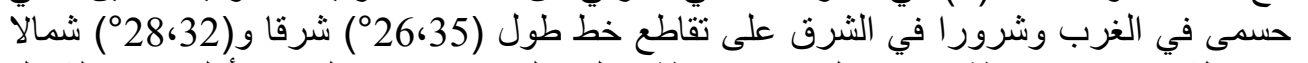

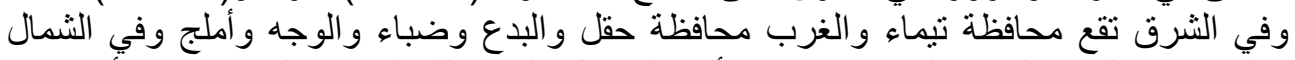

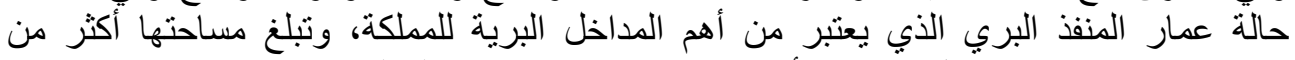
(20400)

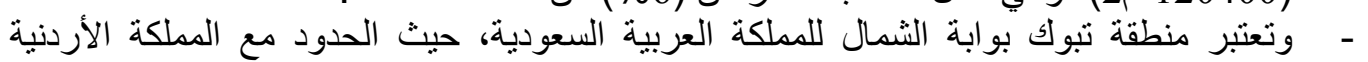

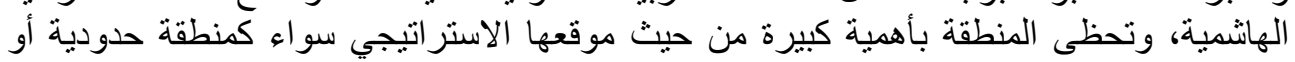

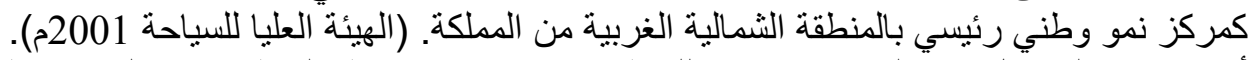

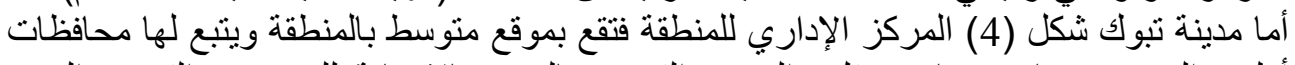

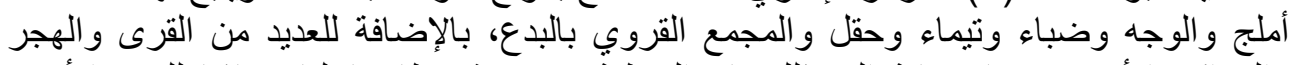

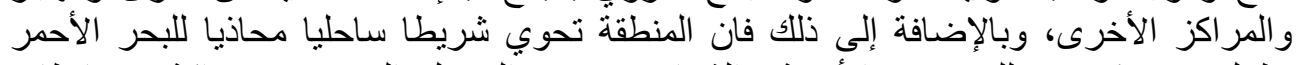

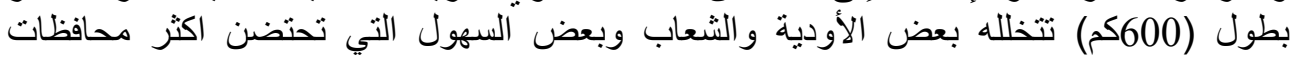




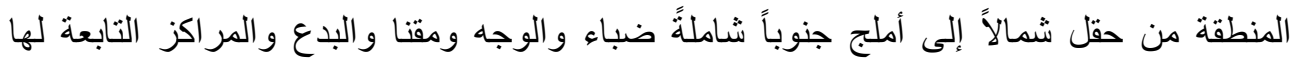

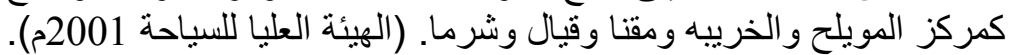

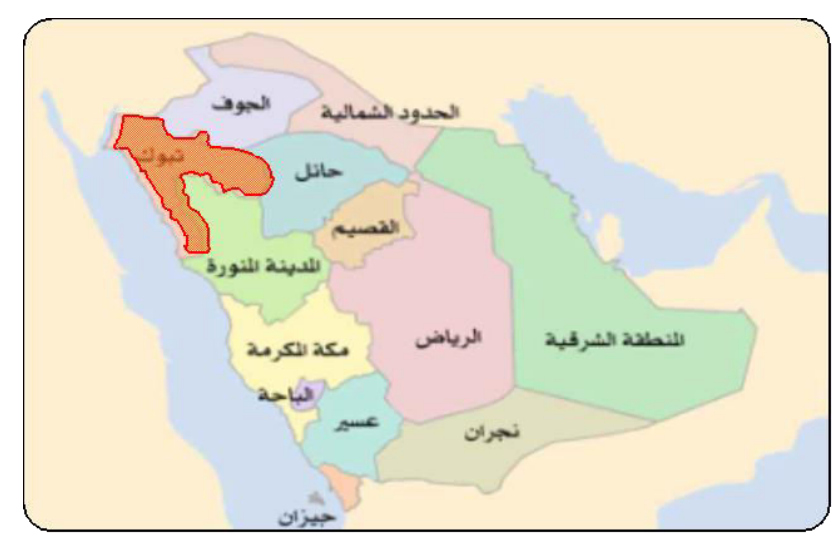

شكل (3) منطقة تبوك و الحدود الإدارية لمناطق المملكة

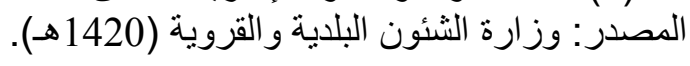

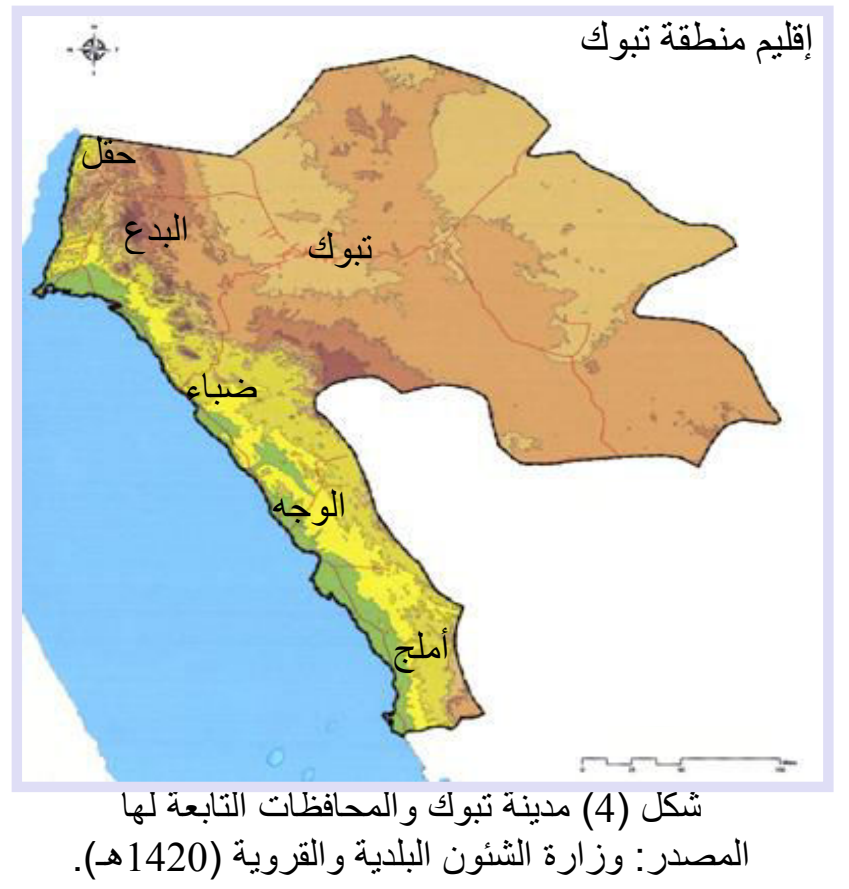


1-4 الخطواتالمنهجية التي يستخدمها البحث في دراسة منطقة تبوك:

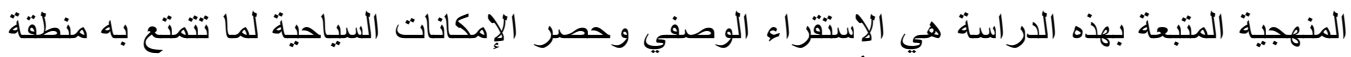

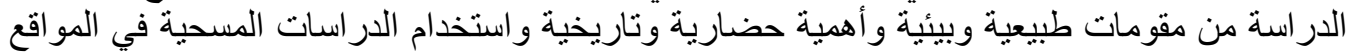

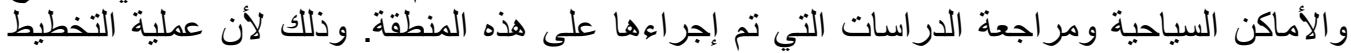

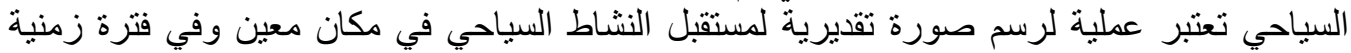

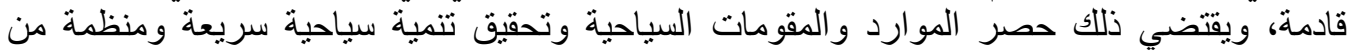

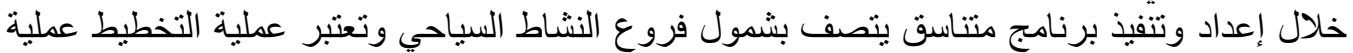

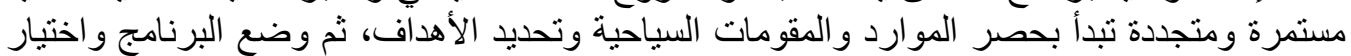

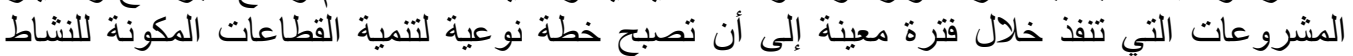

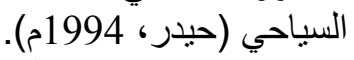
* وقد اعتمدت مصادر الدر اسة بشكل كبير على المعطيات المنبثقة من الاتجاهات التالية:

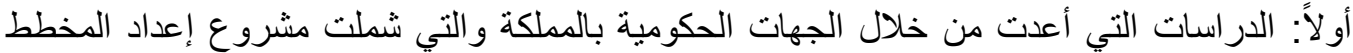

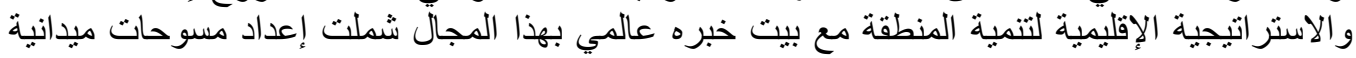

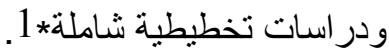

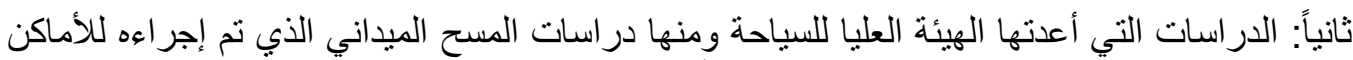

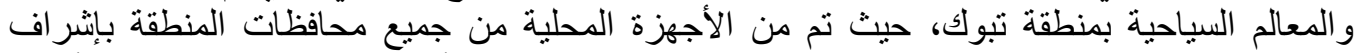

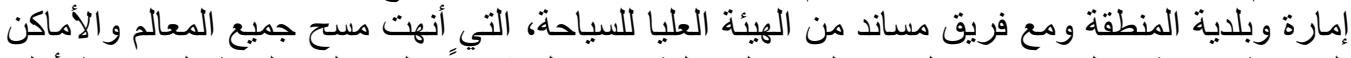

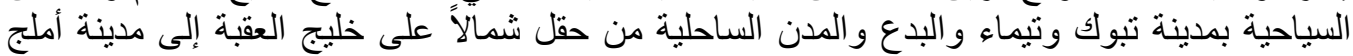

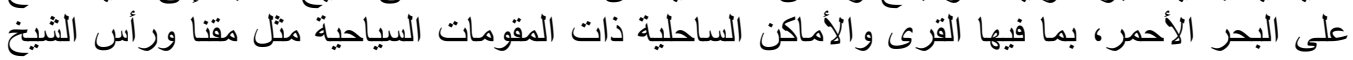

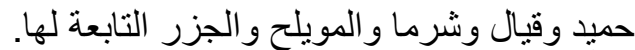

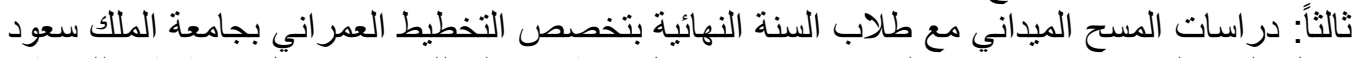

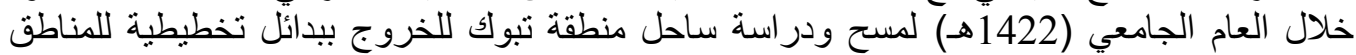

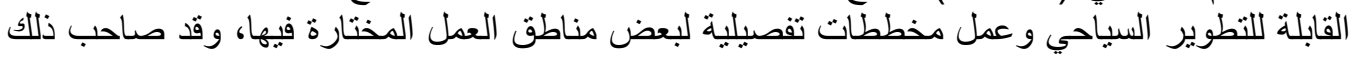

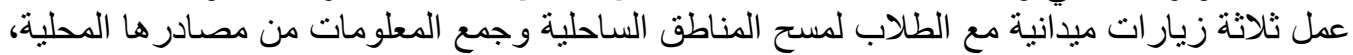

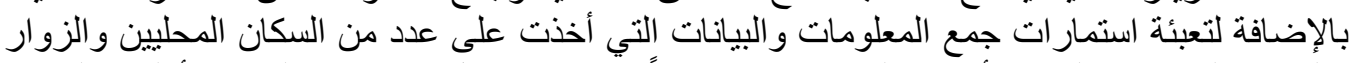

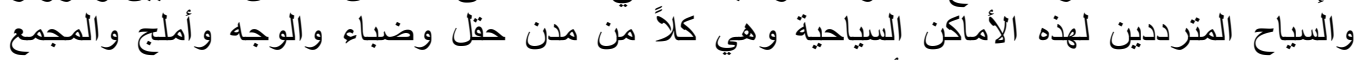

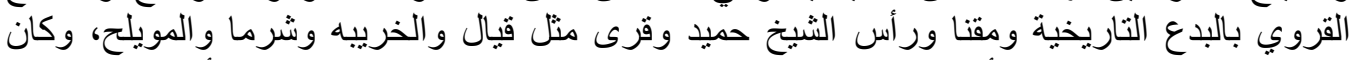

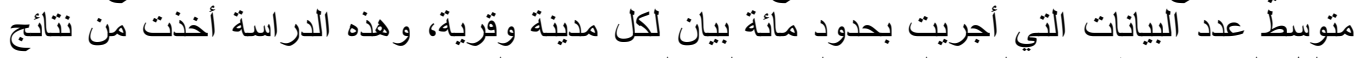

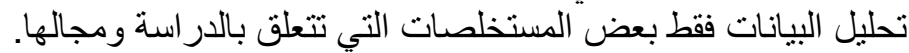

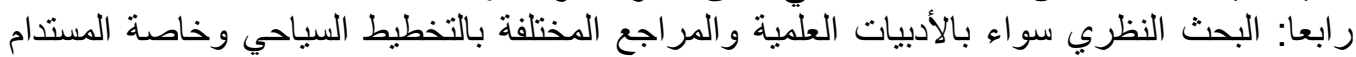

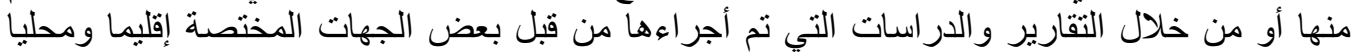

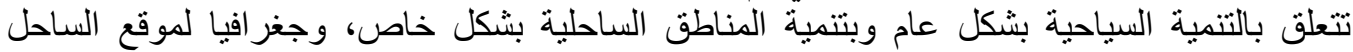

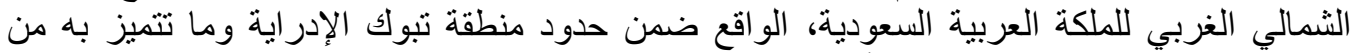
مقومات جغر افية طبيعية وحضرية وأثرية واجتماعية. 2-4 منهجية المسح الميداني لمنطقة الاراسة: من خلال المسح الميداني الذي سبق ذكره لمنطقة الدراسة بالساحل الثمالي الغربي للمملكة العربية

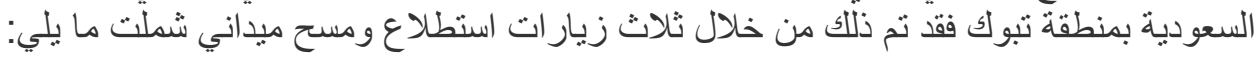

*1 و هذه الدراسات قد شارك الباحث في إعدادها كمدير للمشروع خلال الفترة (1983-1986) 
الزيارة الأولى: بدءاً من مدينة تبوك إلى مدينة حقل في شمال خليج العقبة، ثم البدع التي فيها مقابر

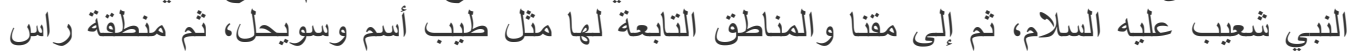

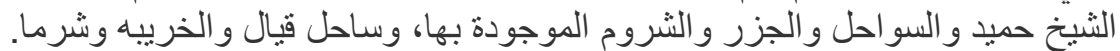

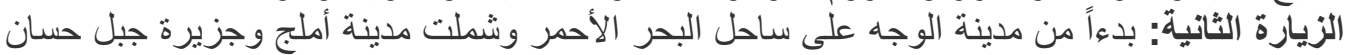

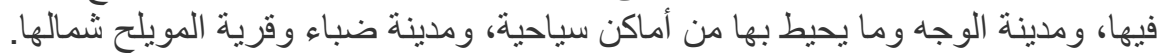

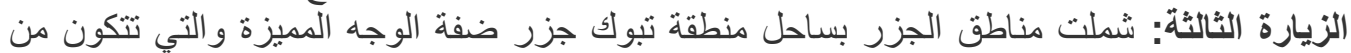

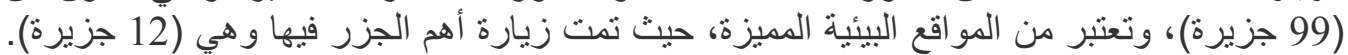

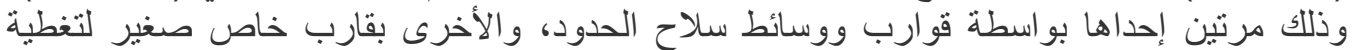
ومسح الجزر التي يصعب الوصائ بول لها بالقوارب الكبيرة بسبب تواجد الثد الثعب المرجانية.

\section{3-4 المعلومات المحددة لتغطيتها بالمسح الميداني لمنطقة الاراسة:}

تطلبت هذه الدر اسة الرجوع للمعلومات النظرية من مختلف مصادر ها، وتغطية ما هو ناقص من من خلاتلال

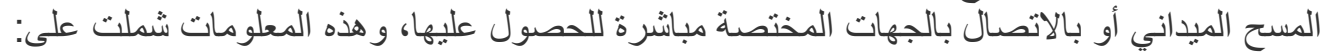

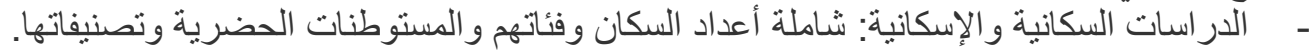

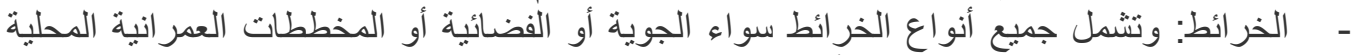

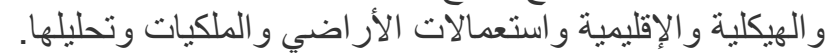
شبكة الطرق: در اسة الأوضاع الرالئة للطرق الارفية المحلية الإقليمية والتدرج الهرمي للطرق و المناطق

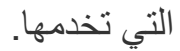
المرافق والخدمات العامة: مسح المرافق والخدمات العامة الراهنة ومستو اها ونطاق خدماتها.

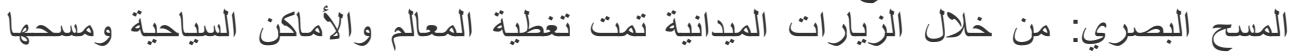

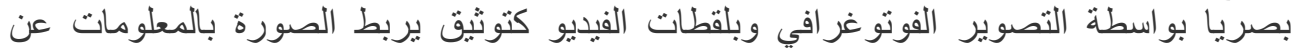

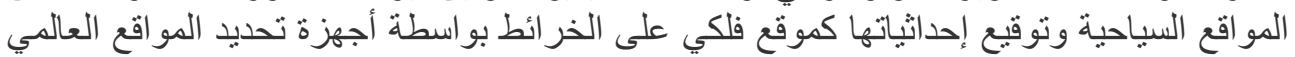

- الدراسات البيئية: وتتمل الخصائص الجيولوجية بواسطة الخرائط الفضائية والصور الجوية

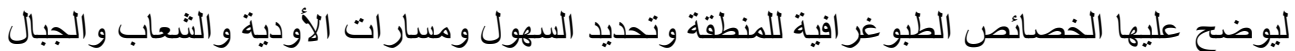

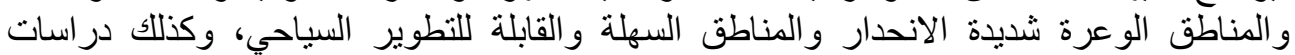

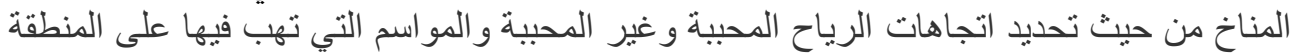

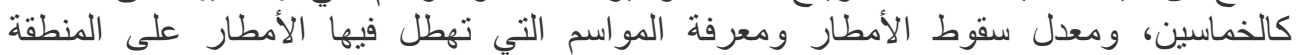

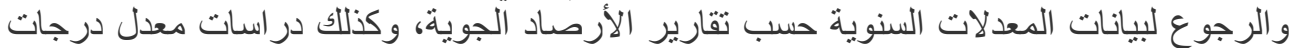

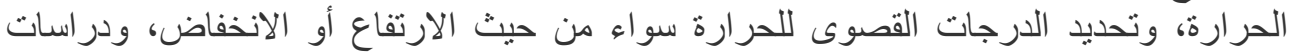

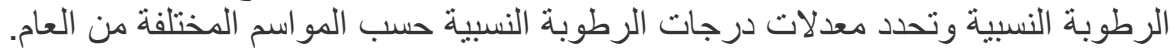

\section{4-4 المناطق ذات الأهمية السياحية التي شملها المسح الميداني:}

ـ المو اقع السياحية المميزة: تحديد المو اقع السياحية و الاستفادة منها بدون الإخلال بجمالها الطبيعي.

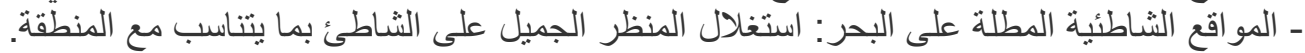

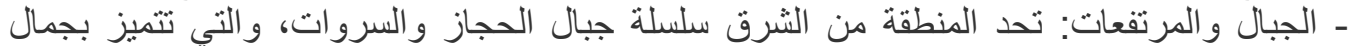

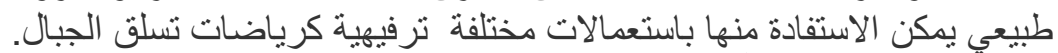

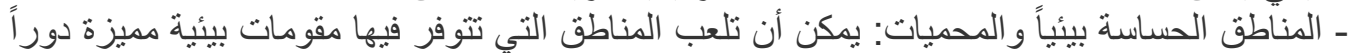

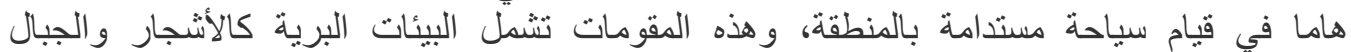

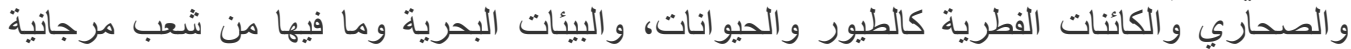

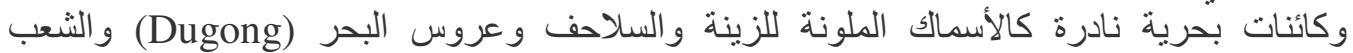
المرجانبة ونباتات الثورى النادرة. 
ـ المواقع الأثرية: تتميز المنطقة بالعديد من المواقع الأثرية التي ستدعم السياحة من الجانب الثقافي

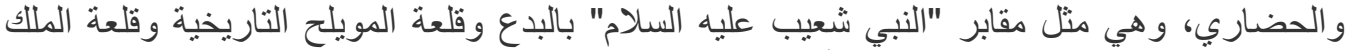

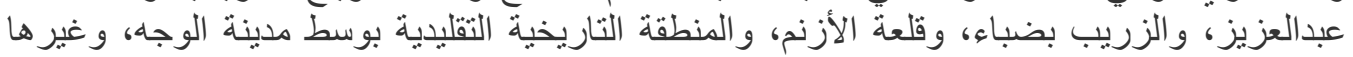
و العديد من المواقع الأثرية التي تحتاج للاهنمام والرياية الراية عند تطوير المنطقة سياحيا بما بضمن

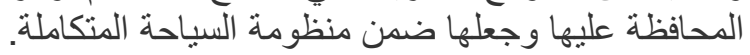

\section{5- المقومات والإمكانات للتنمية السياحية الإقليمية بالساحل الشمالي الغربي للملكة:}

- من أهم النتائج المستخلصة من هذه الدراسات المبدانية هو التعرف على الأوضاع الطبيعية

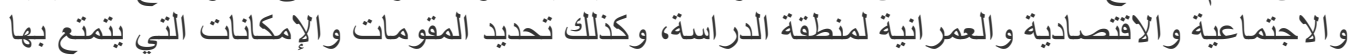

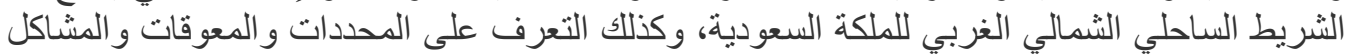

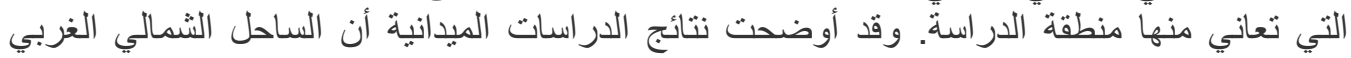

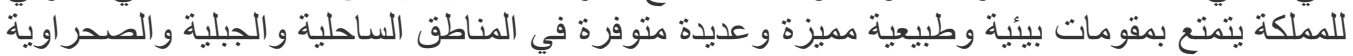

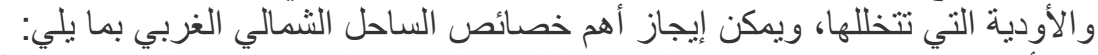

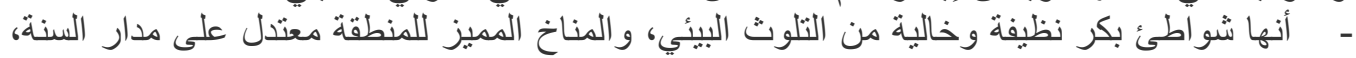

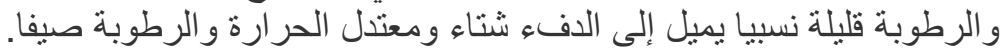

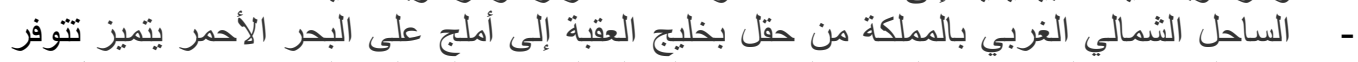

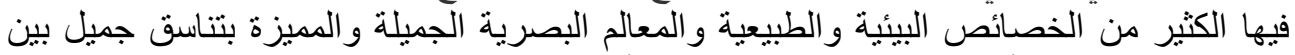

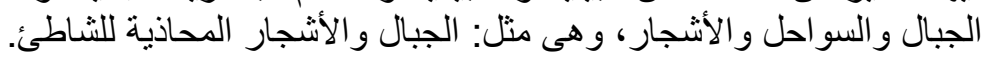

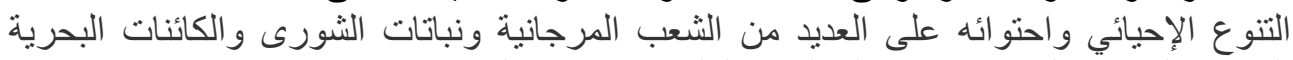

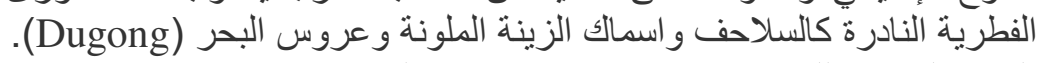

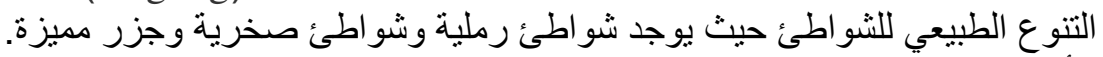

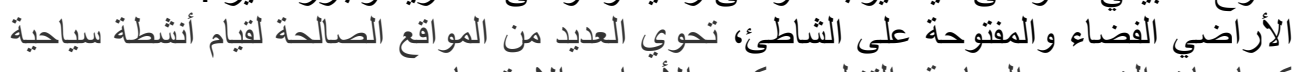

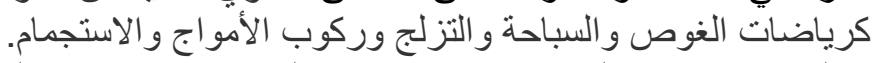

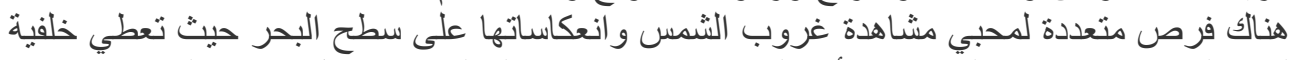

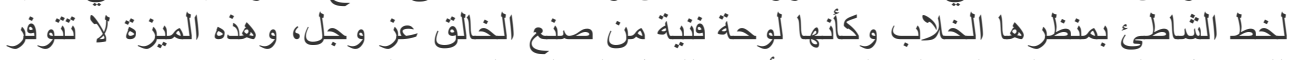

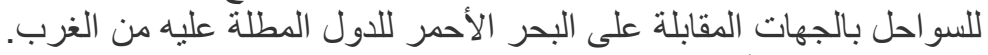

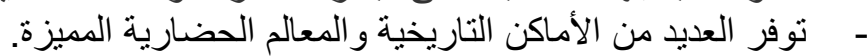
1-5 أهم مناطق الجذب السباحي بالساحل الشمالي الغزبي للمملكة:

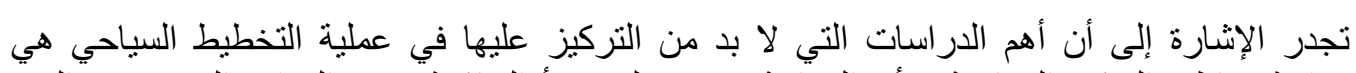

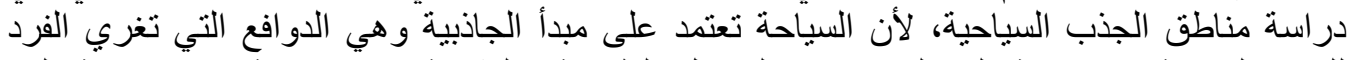

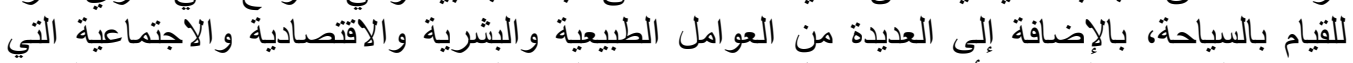

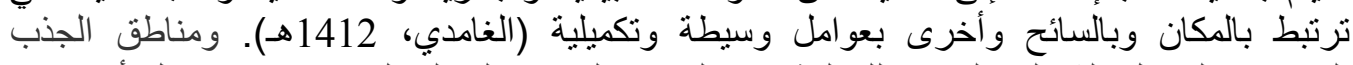

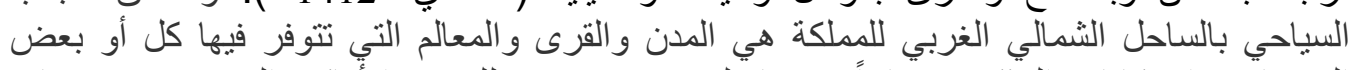

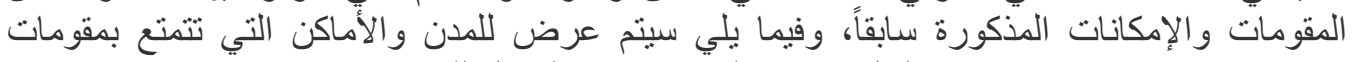

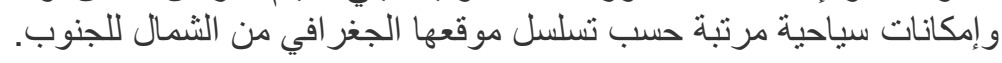

أولا: مدينة حقل:

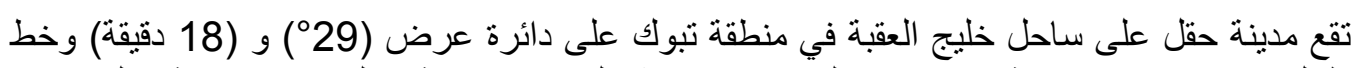

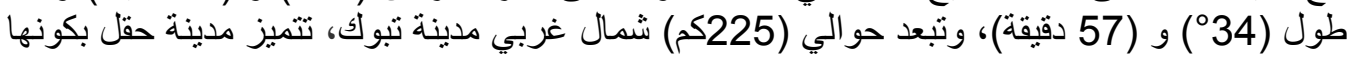




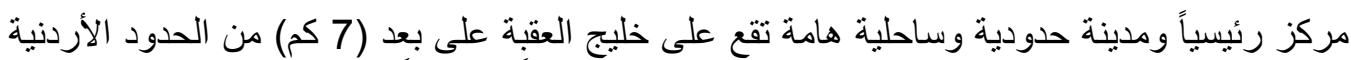

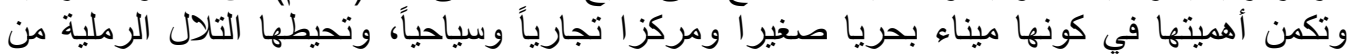

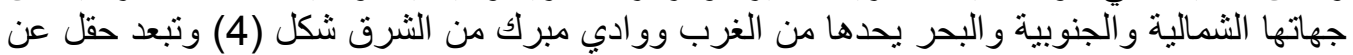

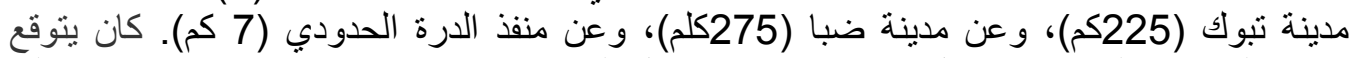

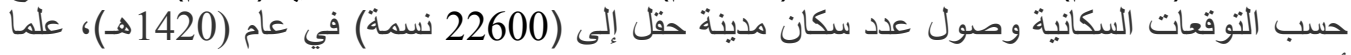

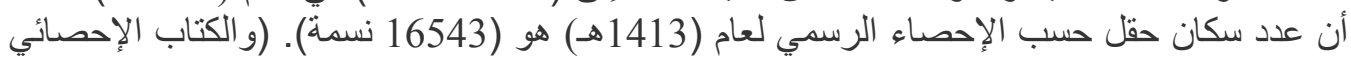

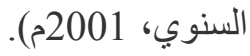
* أهم أماكن الجذب السياحي بحقل:

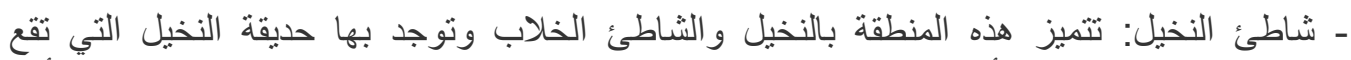

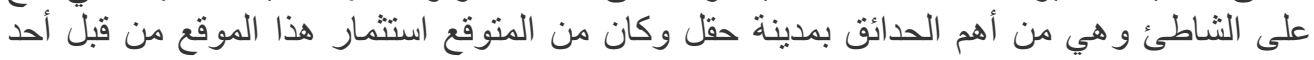
المستثمرين عن طريق البلدية.

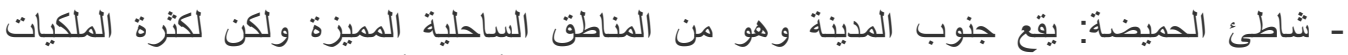

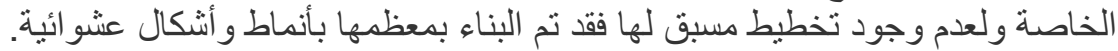

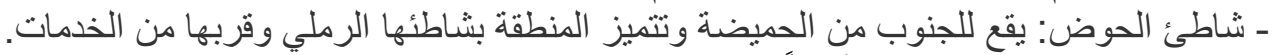

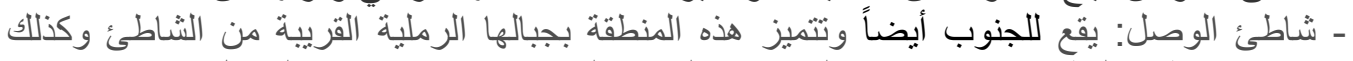

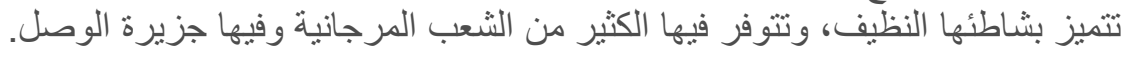
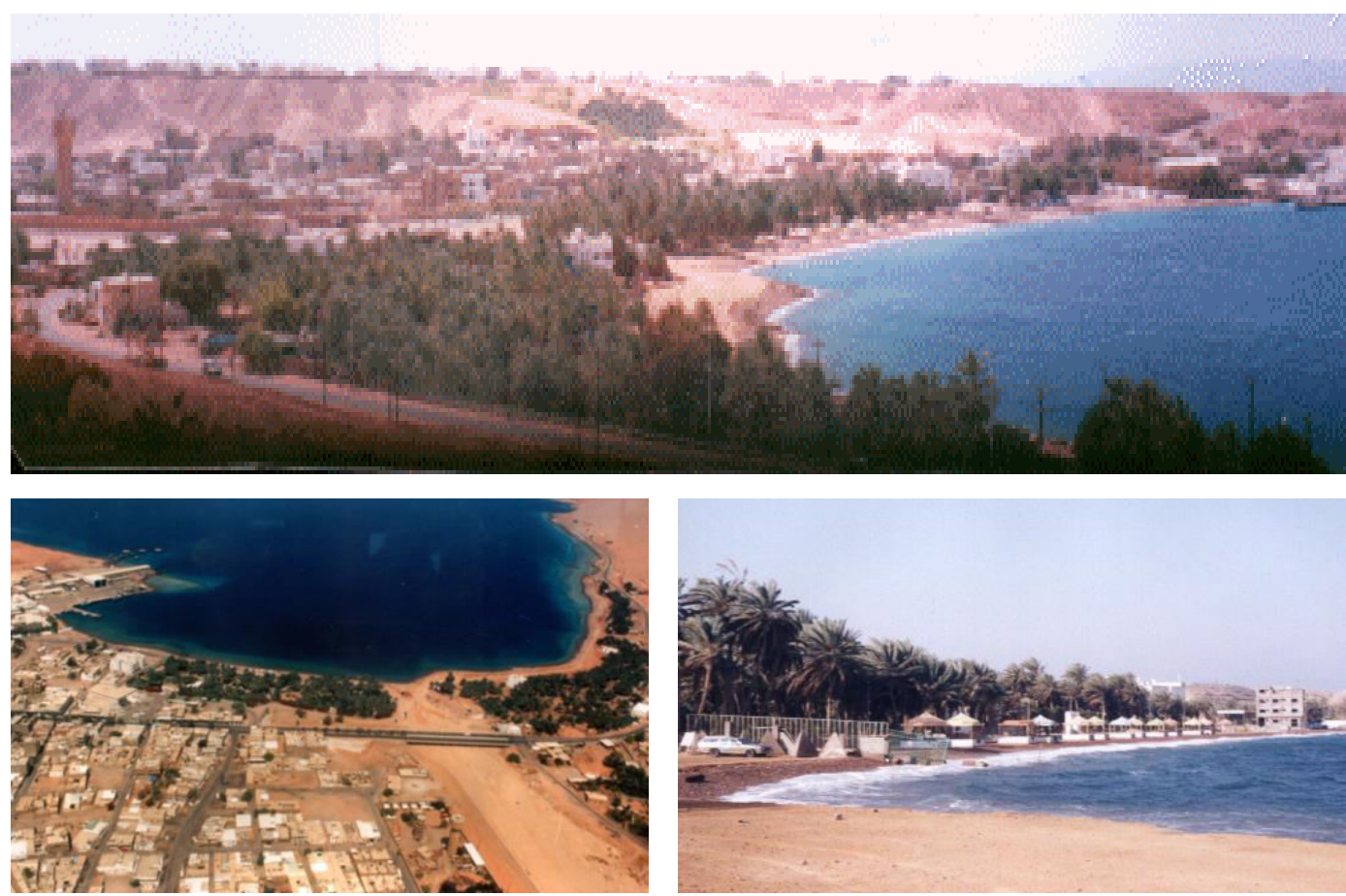

شكل رقم (4) مدينة حقل الساحلية، وشاطئ النخيل للأسفل يمين

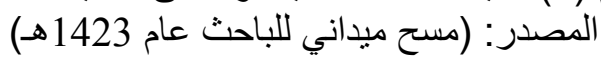




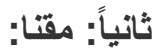

تقع مقنا ضمن محافظة حقل وتتبع لها إداريا، وتتكون المنطقة من ثلاثة عناصر طبيعية رئيسية (الجبل

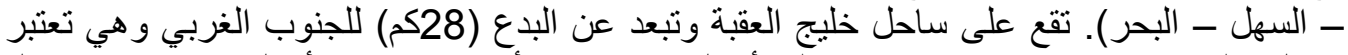

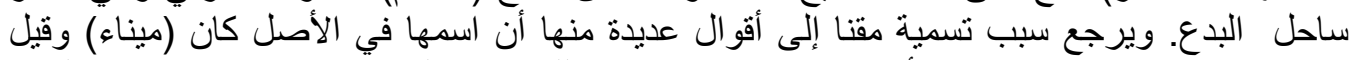

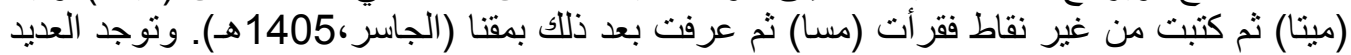

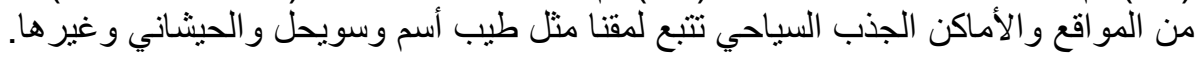

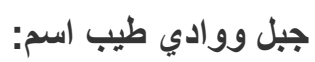

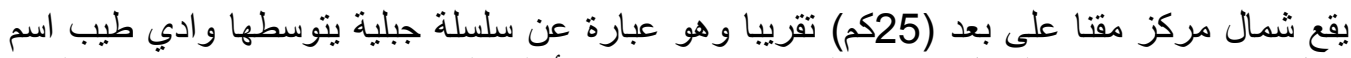

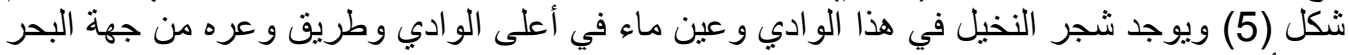

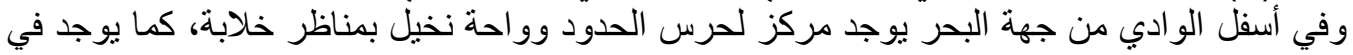
ساحلها منطقة غوص معروفة تتردد عليها فرق من هو اة ومحترفي الغوص.
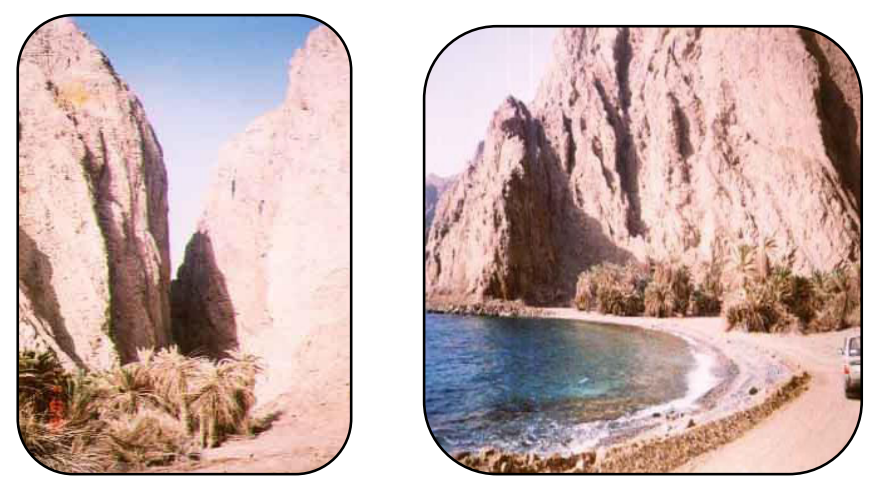

$$
\text { شكل رقدم (5) جبل وو ادي طيب أسم - قرب مقنا. }
$$

- سويحل: يقع شمال مركز مقنا بحو الي (20كم) على ساحل خليج العقبة وهو عبارة عن شنو شاطئ رملي

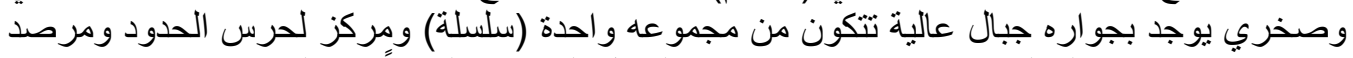

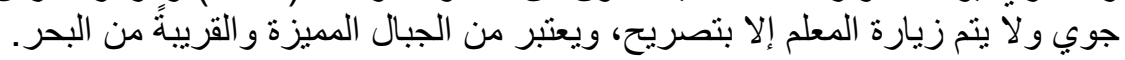

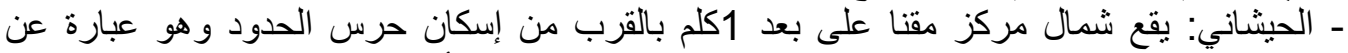

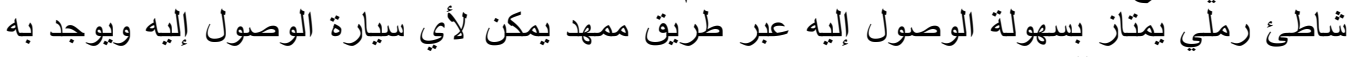

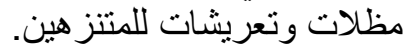

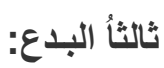

تقع البدع ضمن حدود محافظة حقل، وتتكون المنطقة من عنصرين طبيعيين رئيسيين هما ( الجبل -

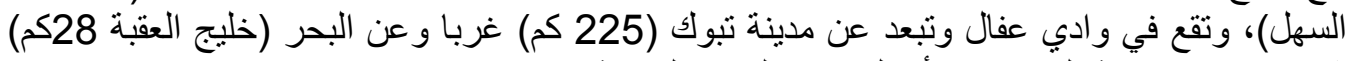

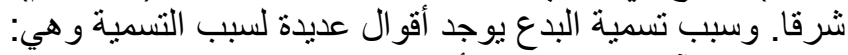
-

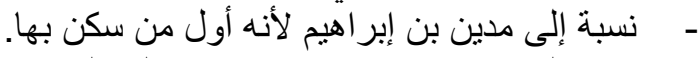
- نسبة إلى إبداع بن مدين بن إبر اهيم عليه السلام. 


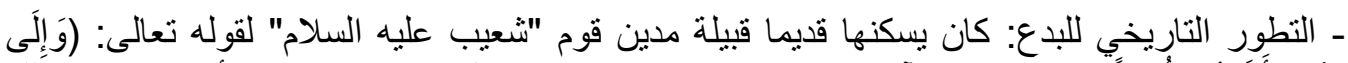

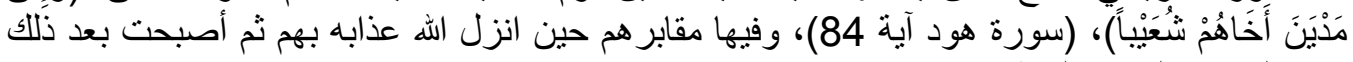

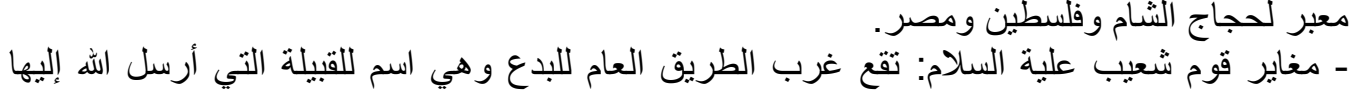

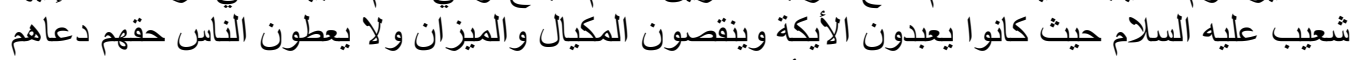

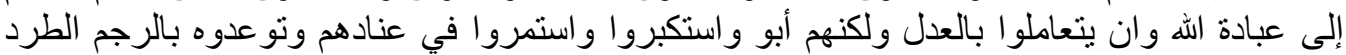

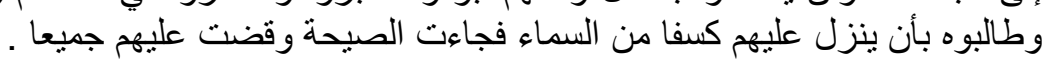
رابعاً: قيال ورأس الثيخ حميد:

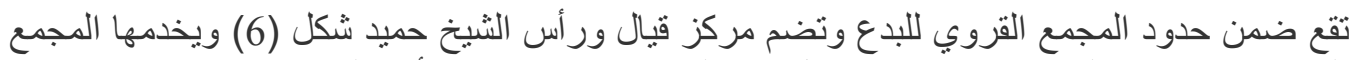

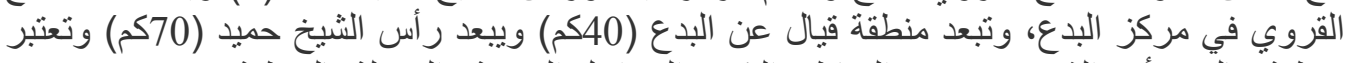

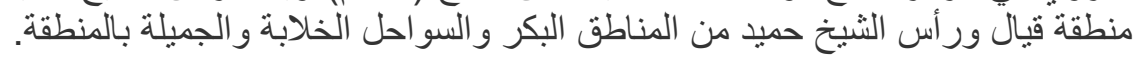

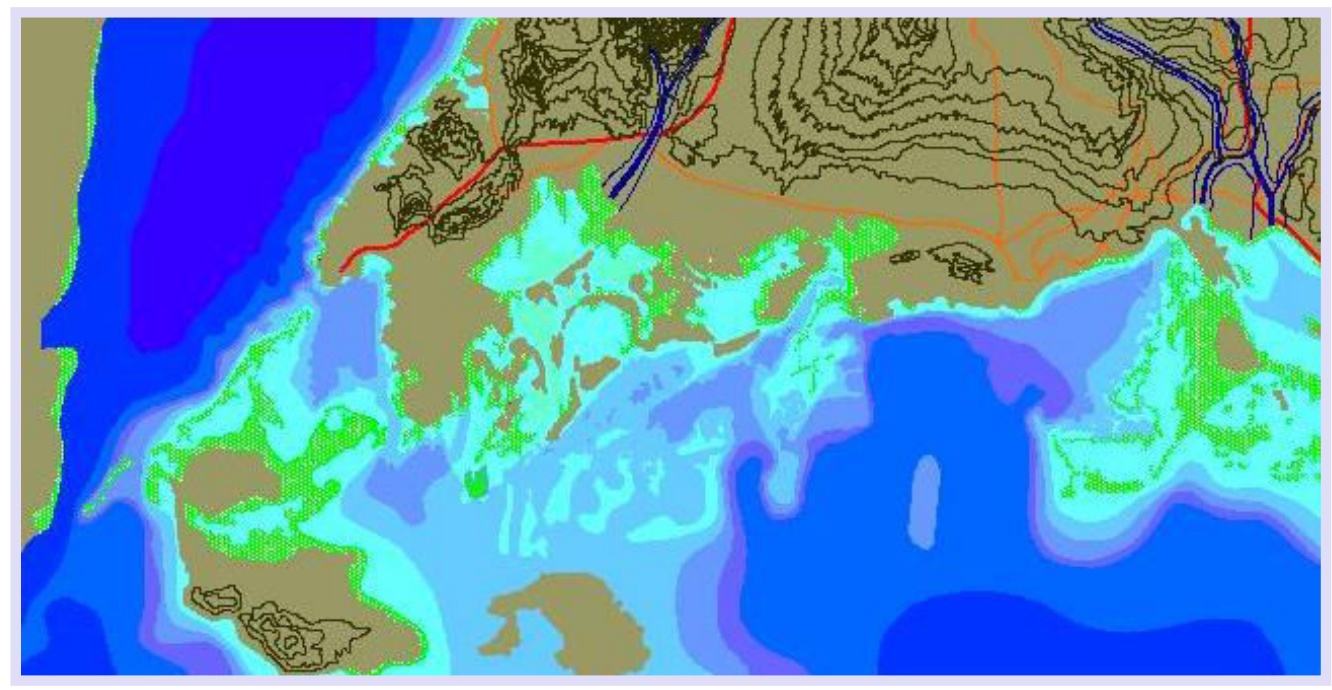

شكل رقم (6) صورة (فضائية بالأقمار الصناعية) توضح قيال

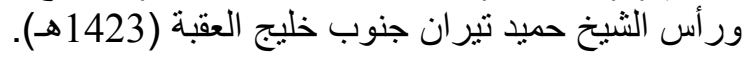

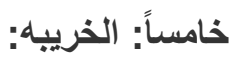

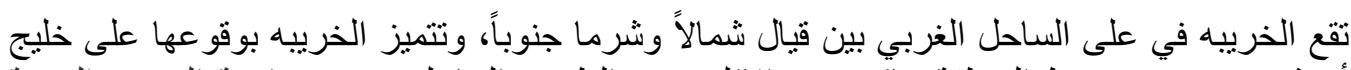

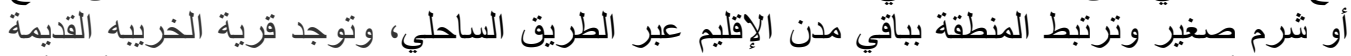

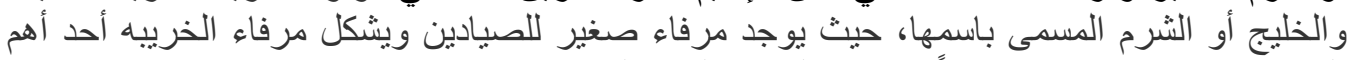

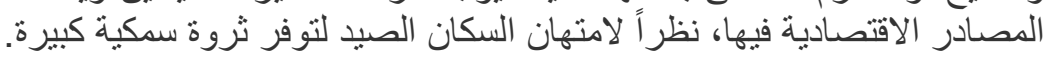

سادساً: شرما:

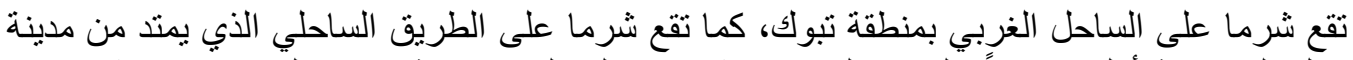

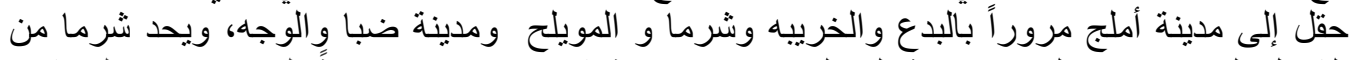

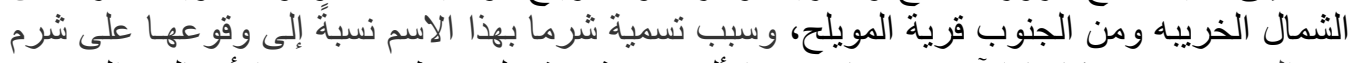

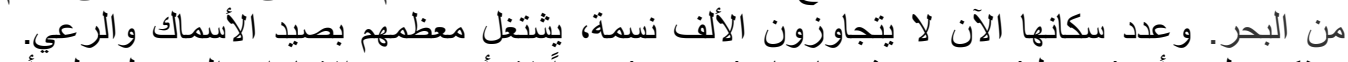

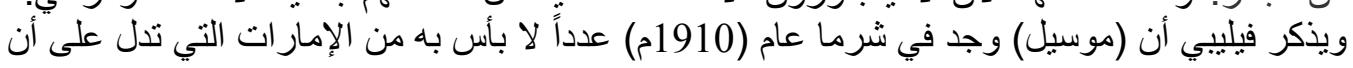




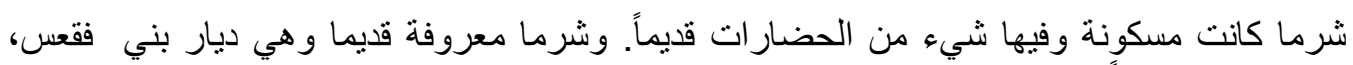

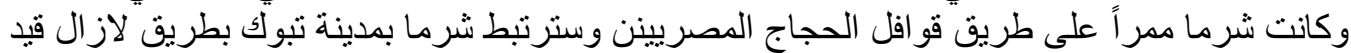

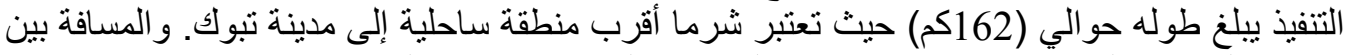

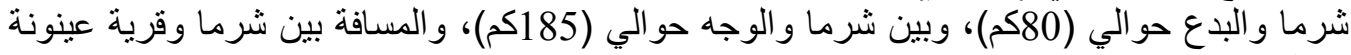
حوالي (25 (م)م). سابعاً: المويلح: (دوب) - قرية المويلح: وتبعد (ك45م) إلى الشمال من مدينة ضباء ومن أهم المقومات السياحية بها هي قلعة

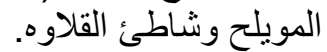
قلعة المويلح: قلعة يرجع تاريخها إلى سنة (968هـ) وهي من المحطات الرئيسية على طريق

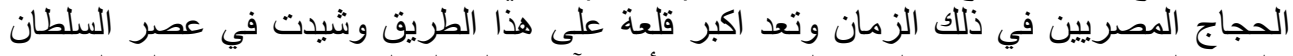

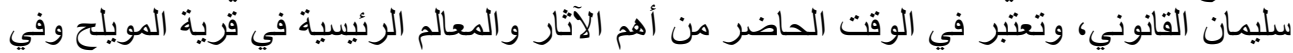

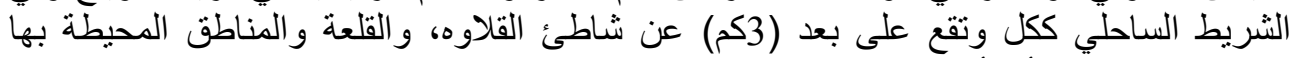

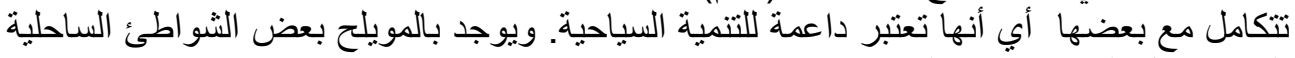

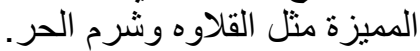
شاطئ القلاوه: وهو عبارة الفوه عن ساحل بطول 3 كلم تقريبا ويتميز بوجود مناطق للسباحة ودناطق لصيد الأسماك و هو من أهم المواقع السياحية في القرية. وتكثر أثجار النخيل على على هذا الساحل

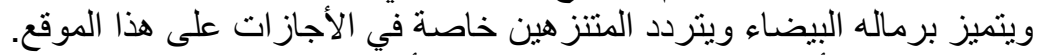

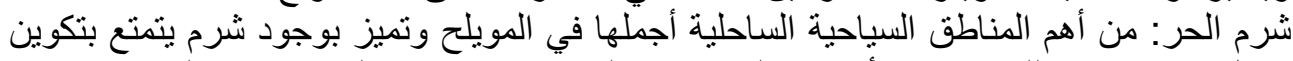

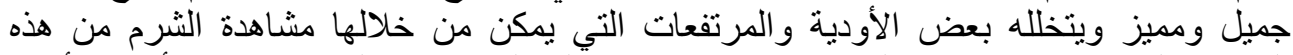

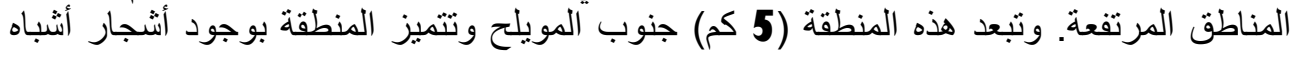

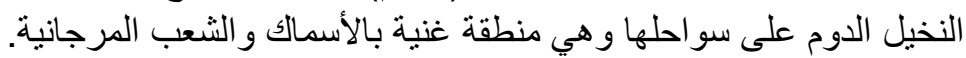

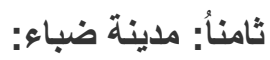

تقع ضباء على ساحل البحر الأحمر بمنطقة تبوك وتبعد عن مدينة تبوك حوالي (180كم) ويرجع

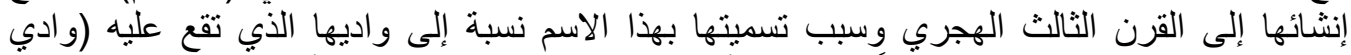

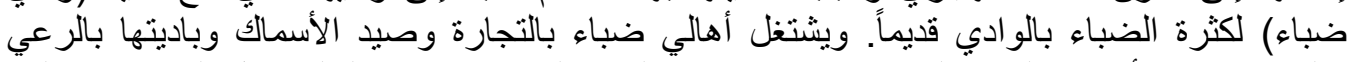

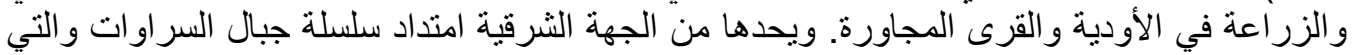

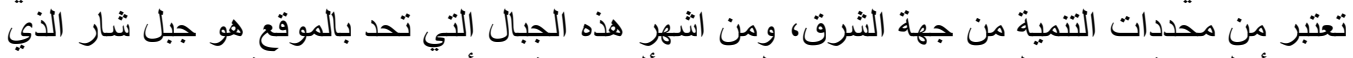

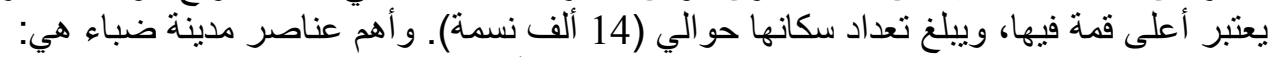
- - الثرم: تقع هذه المنطقة في وسط مدينة ضباء وهي أقدم منطقة فيها وتثميز هذه المنطقة بكورنيش

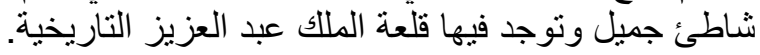

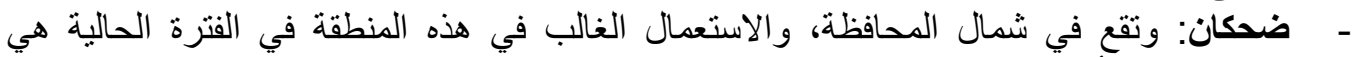

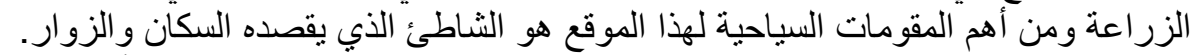

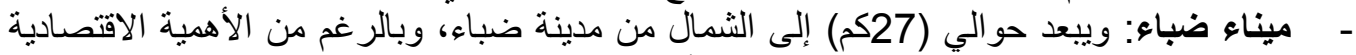

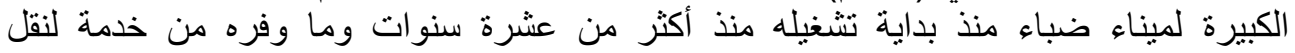

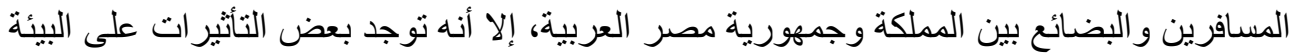

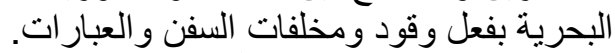

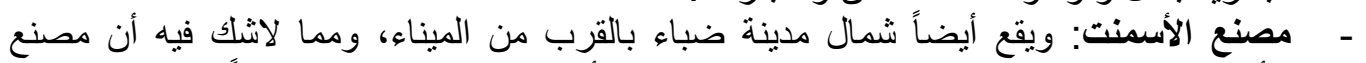

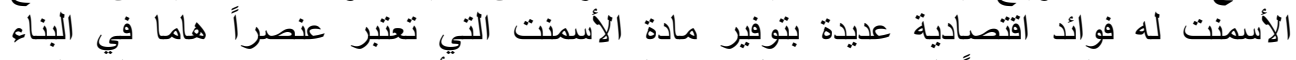

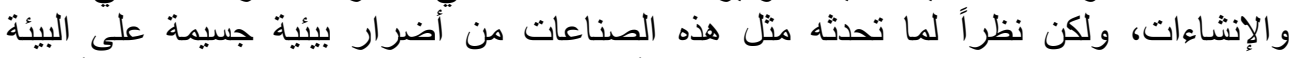

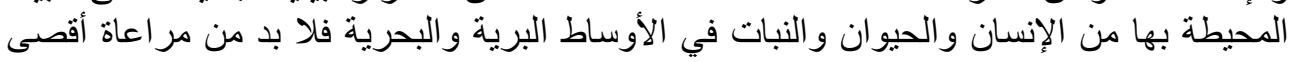


المعايير و المقاييس للحد من هذه التأثيرات السلبية لاسيما و أن موقع المصنع يقع شمال مدينة ضباء وبالقرب من الميناء و الثو اطئ الجميلة للمنطقة.

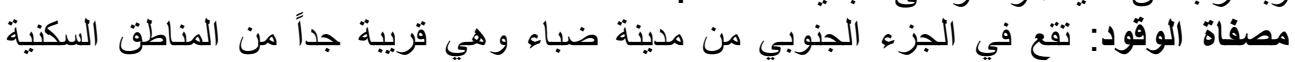

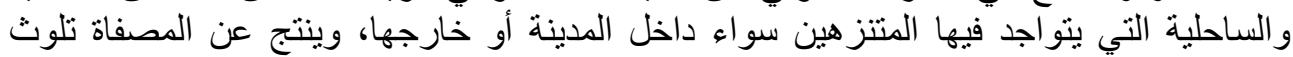

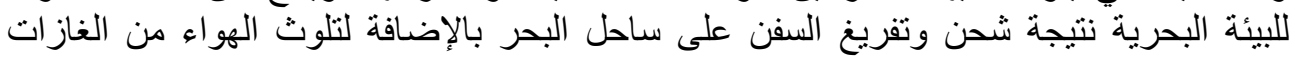
المنبعثة منها.

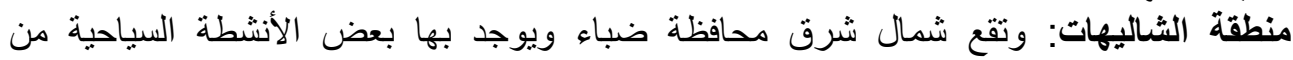

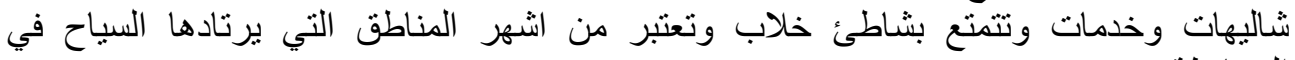
المحافظة. شاطئ السجدة: تقع هذه المنطقة في شمال مدينة ضباء على بعد (20كم) وهي من المناطق الغنية

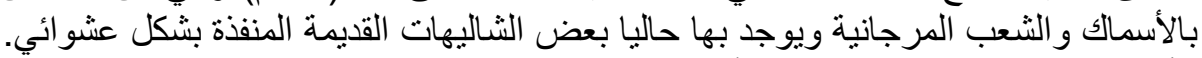

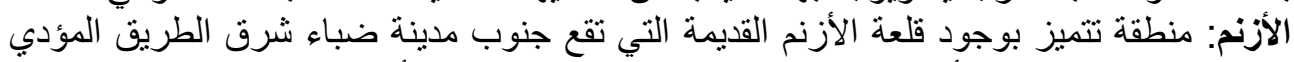

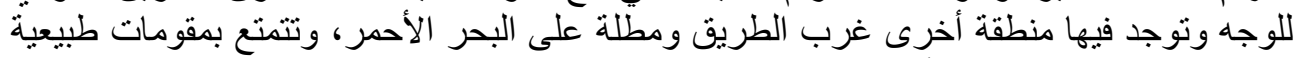
كاللثعب المرجانية وتوفر الأسماك.

تاسعاً: مدينة الوجه:

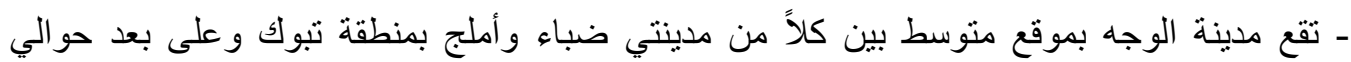

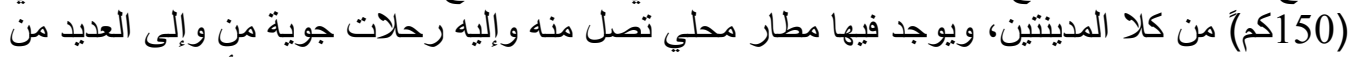

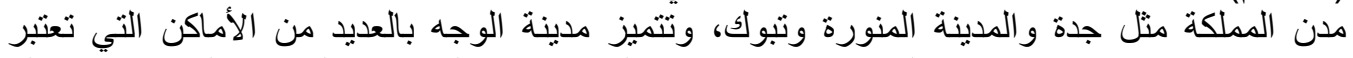

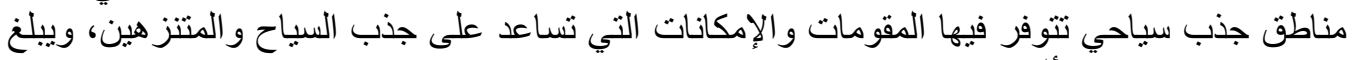
تعداد سكانها عشرون ألف نسمة فئمة

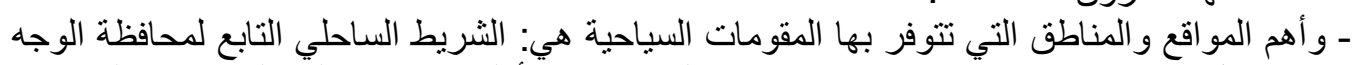

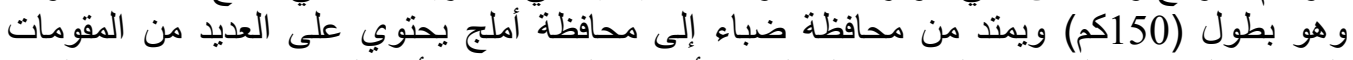

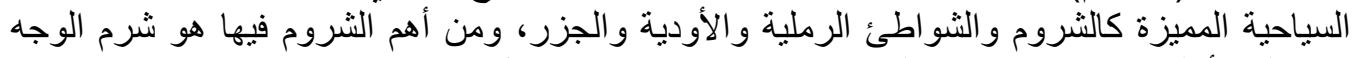
و هو المرفأ الطبيعي بوسط مدينة الوجه، وشرم هبان الرمبة والأودية واش شكل (7).
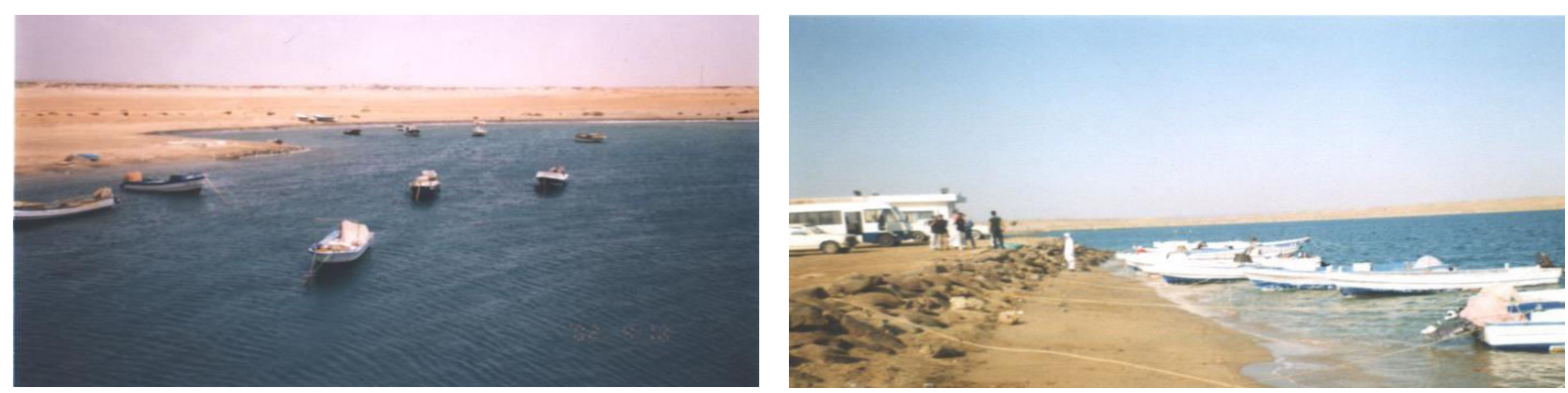

$$
\text { شكل رقم (7) شرم هبان لليمين وشرم غو اشان لليسار جنوب الوجها. }
$$

الثواطئ الساحلية: نوجد بمحافظة الوجه العديد من الثو اطئ داخل المدينة وخارجها، ومنها: ولها:

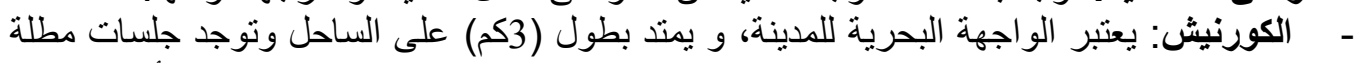

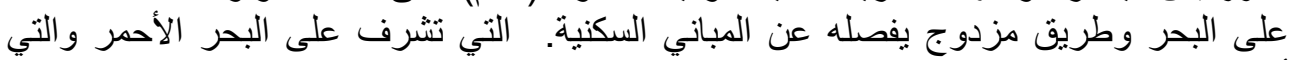
أخذت تتحول إلى مر اكز سياحية.

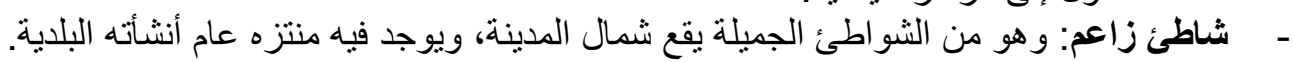


- منتزه الأمير فهـ بن سلطان: تقع شمال المدينة، وتضم مجموعة من الثاليهات التي تؤجر من قبل

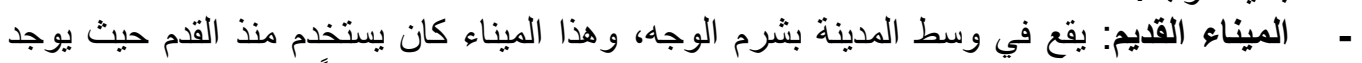

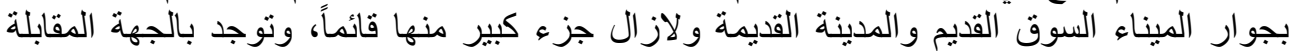
آثار لفنار قديم لإرشاد السفن. ويعتبر الميناء مورد اقتصادي لجذب الفير الركاب والبضائع وصيد

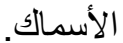
- الأودية: تغطي محافظة الوجه شبكة من الأودية تتجه من الجبال الثرقية إلى ساحل البحر الأحمر

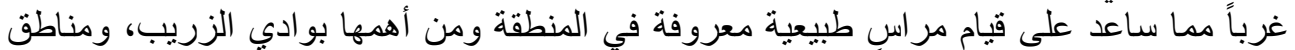

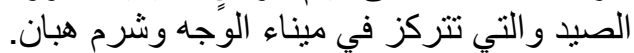

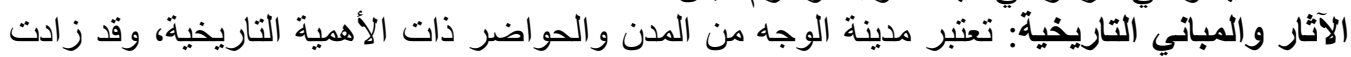

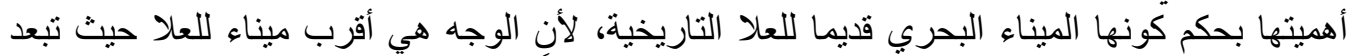

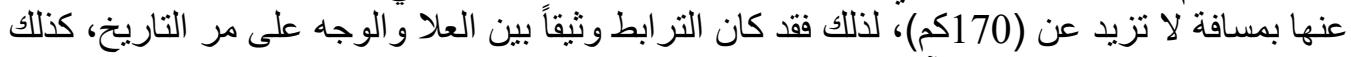

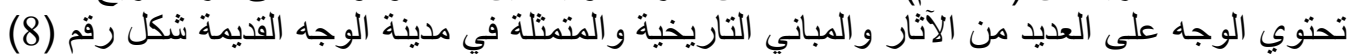

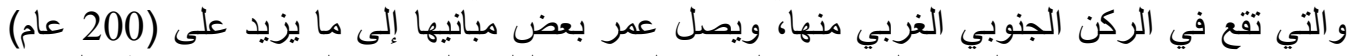

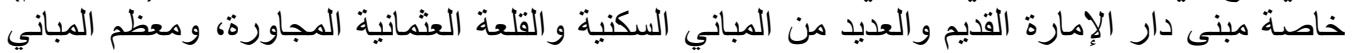

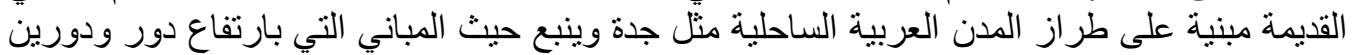

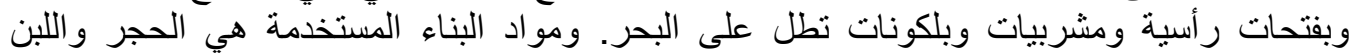

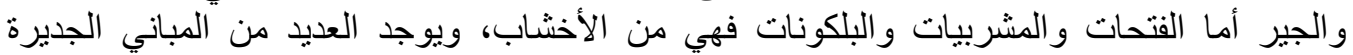

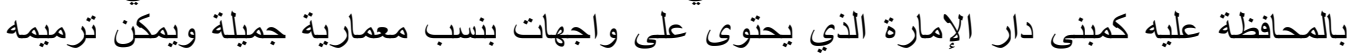

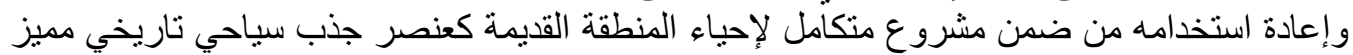

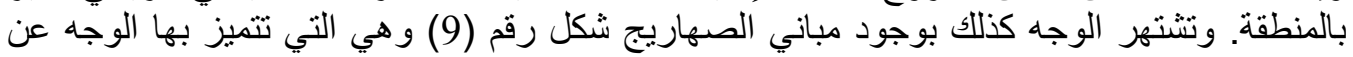

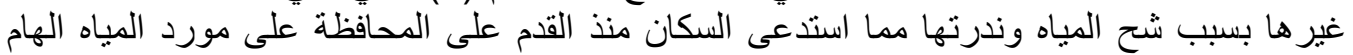

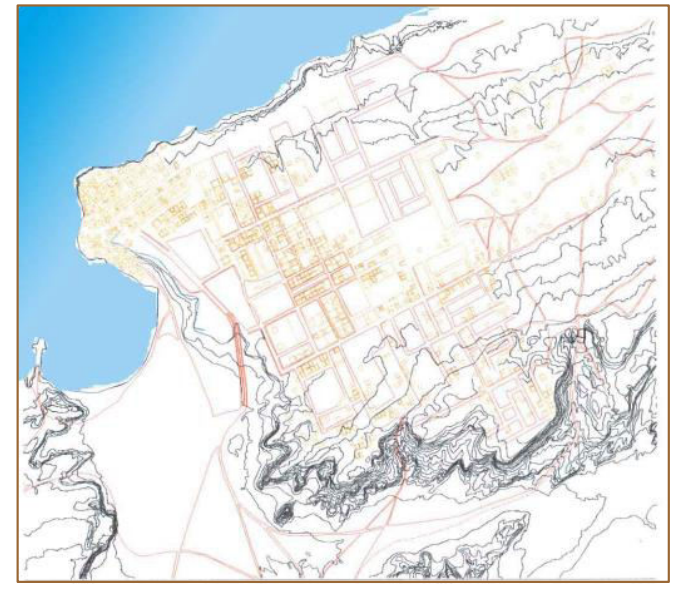

شكل رقم (8) صور جوية لمدينة الوجه و البلدة القديمة فيها. وتخزينه وحفظة بطريقة الصهاريج.
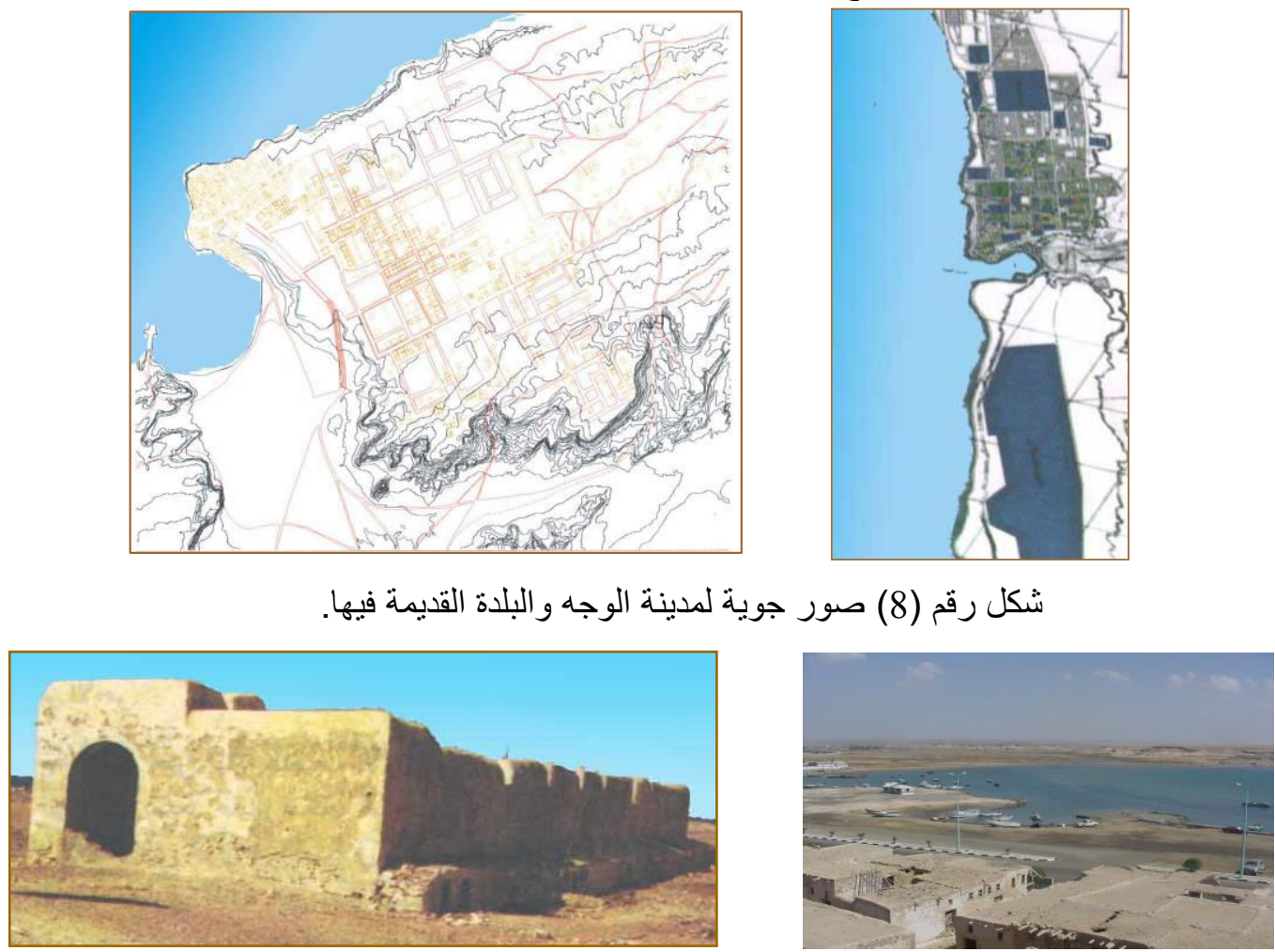

شكل رقم (9) لليمين شرم الوجه الميناء و السوق القديم، ولليسار أحد صهاريج المياه المشهورة بها الوجه. 


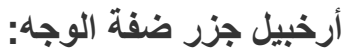

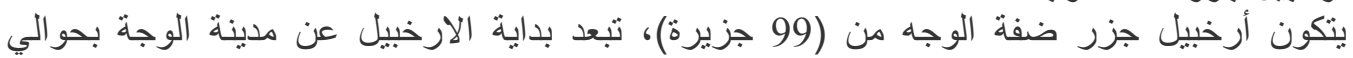

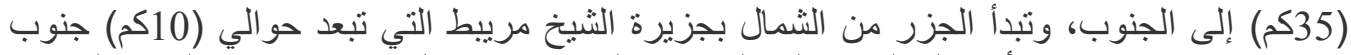

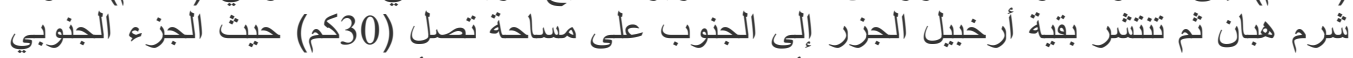

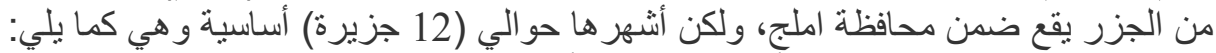

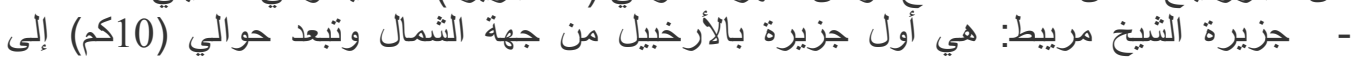

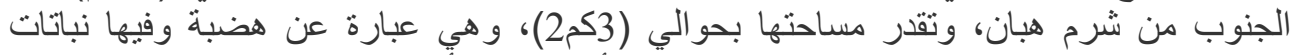

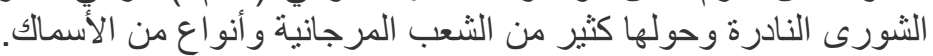

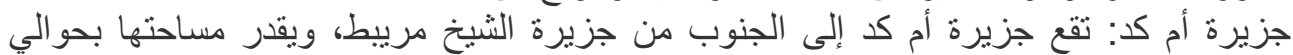

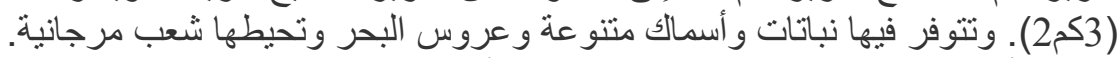

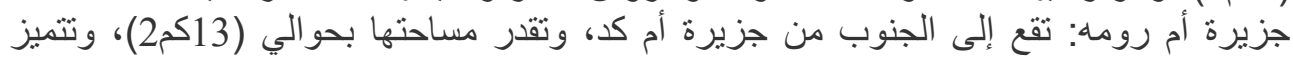

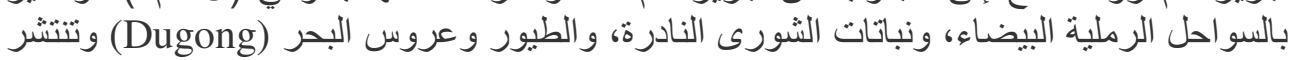
حولها شعب مرجانية.

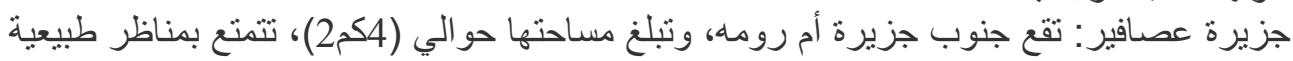

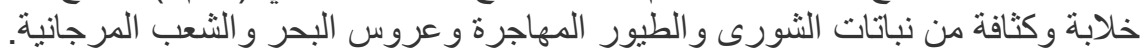

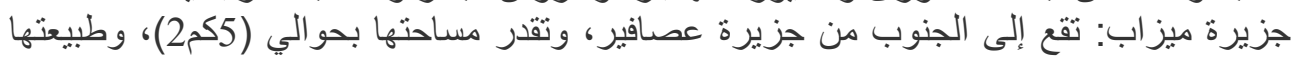

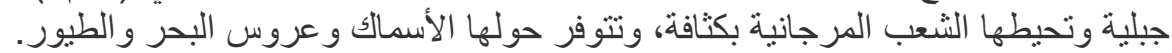

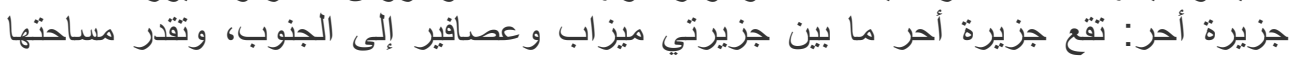

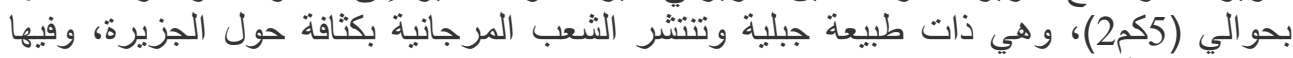

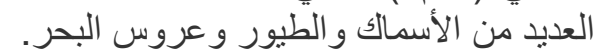
جزيرة بريم: تقع إلى الجنوب الغربي من جزيرة البحرة أحر، وتعتبر من أكبر جزر أرخبيل ضفئة الوجها

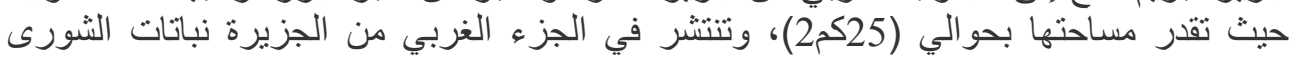

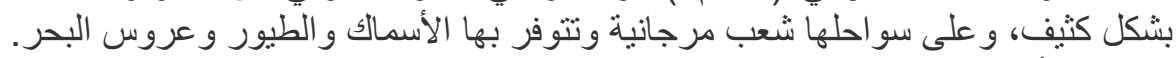

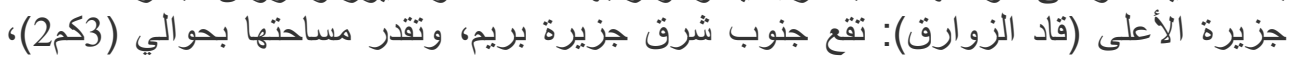

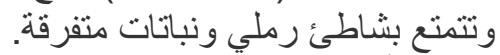

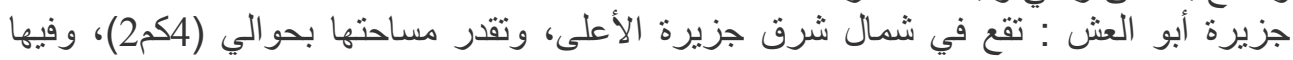
بعض النباتات وتكثر بها الطيور المهاجرة.

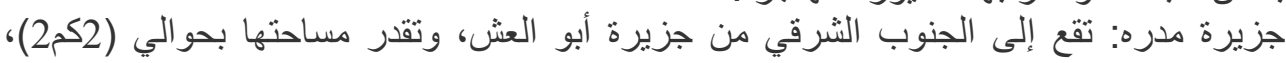

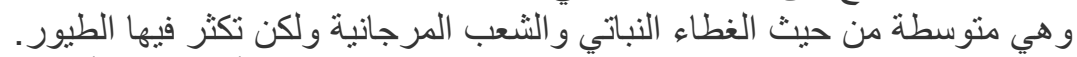

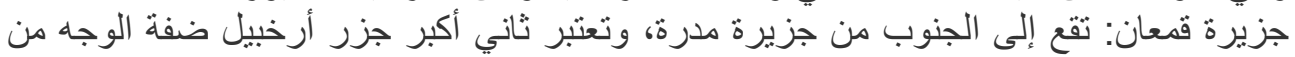

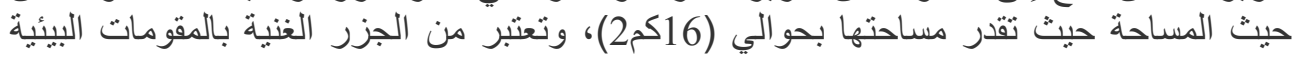

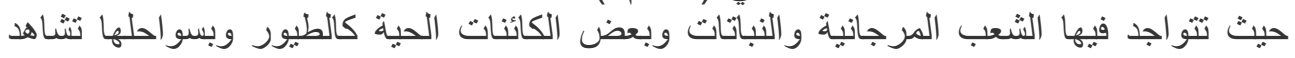
عروس البحر والسلاحف بمو اسم معينة.

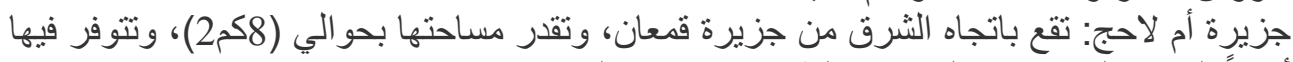

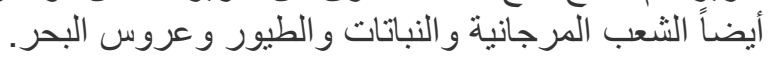


ـ تقع مدينة أملج في أقصى الجنوب بمنطقة تبوك ويحدها جنوباً محافظة ينبع التابعة لمنطقة المدينة

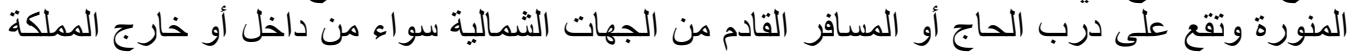

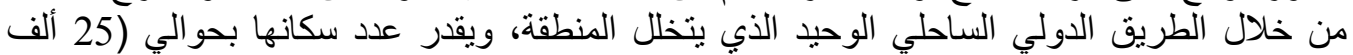
نسمة) وتعتبر أكبر مدينة بالمنطقة بعد مدينة تبولي الك من حيث الحجم والكثافة السكانية. ويتبع لمحافظة

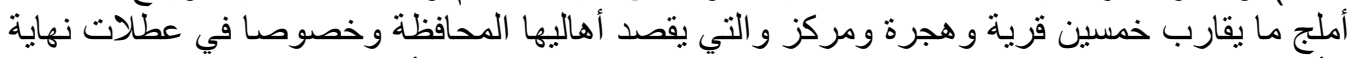

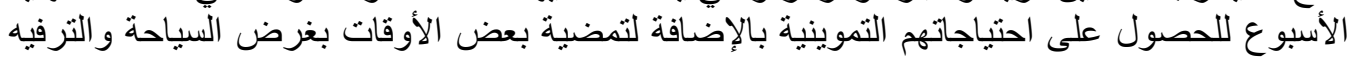

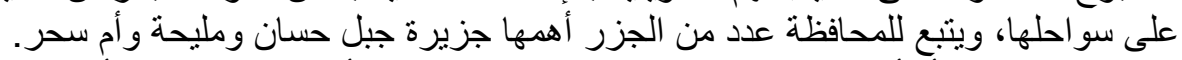

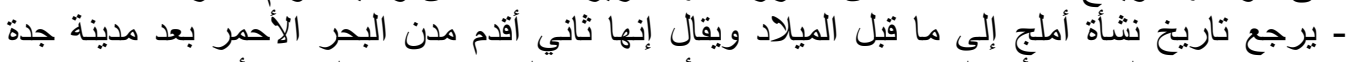

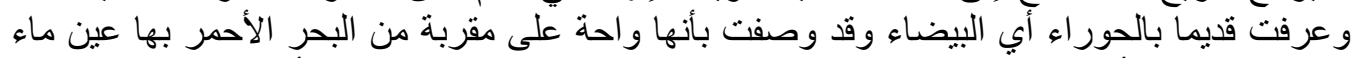

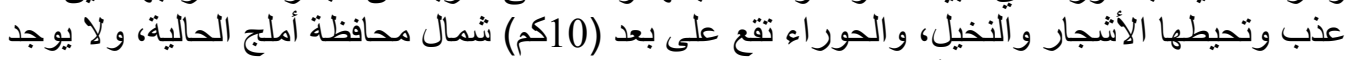

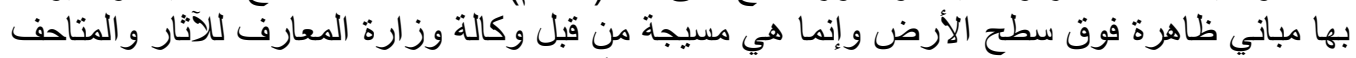

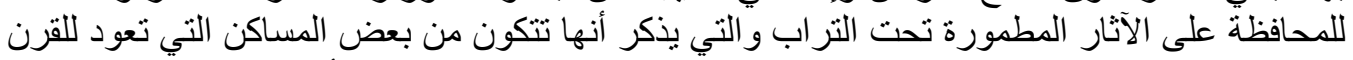

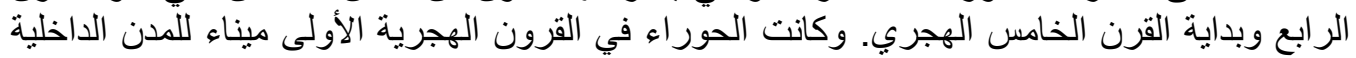

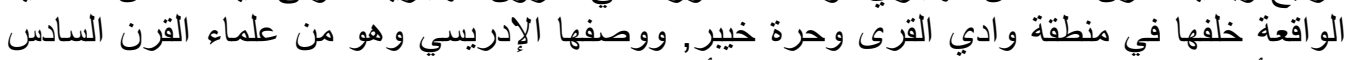

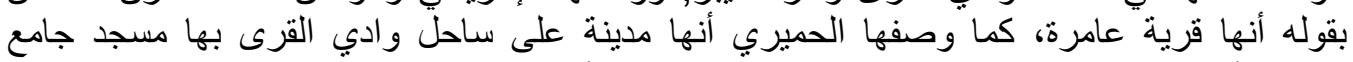

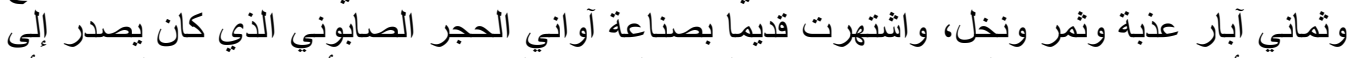

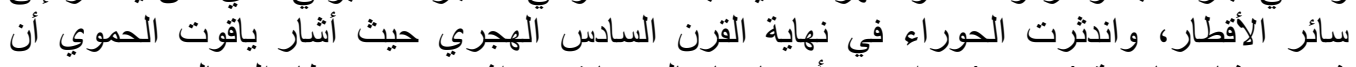

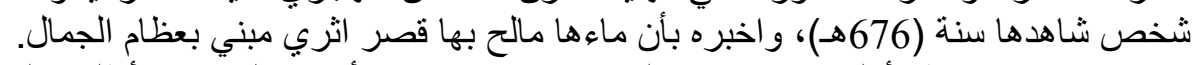

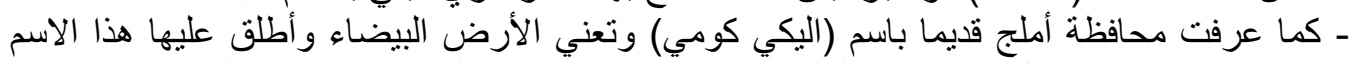

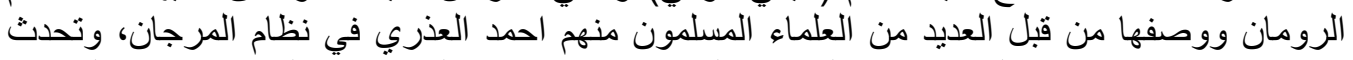

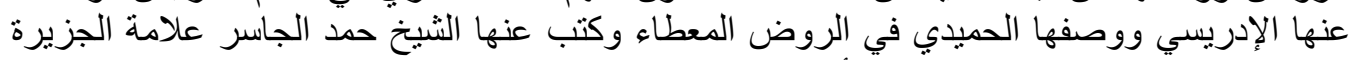

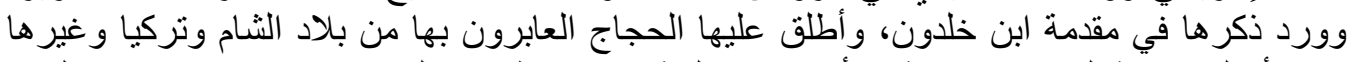

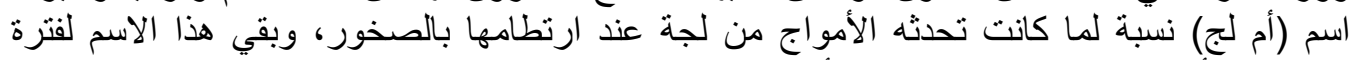
طويلة إلى أن دمج في كلمة واحدة هي (أملج). ويوجد بها بعض كن المواقد ذات ذات الجذب السياحي مثل:

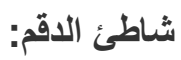

و هو شاطئ رملي شكل رقم (10) يتمتع بمناظر خلابة تجمع بين الساحل الرملي وأشجار النخيل

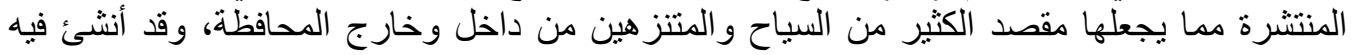

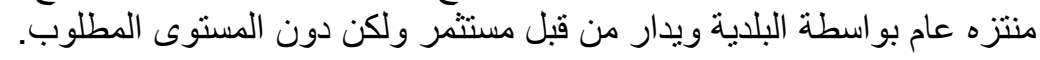
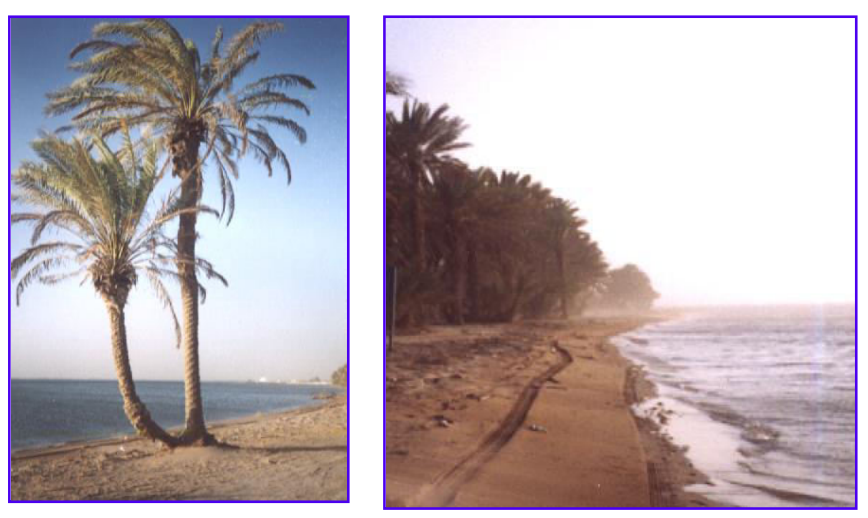

شكل رقم (10) شاطئ الدقم - أملج.

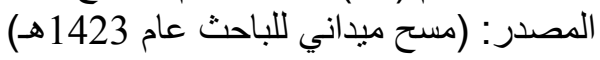




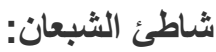

و هو شاطئ يقع جنوب محافظة أملج بحوالي (20كم) تقريبا، وهو من المون الموانئ القديمة التي كانت

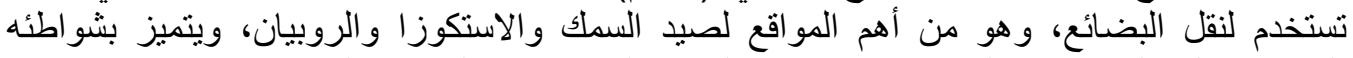

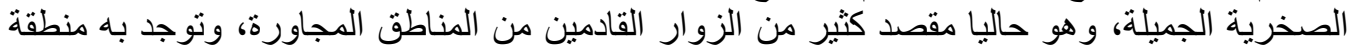

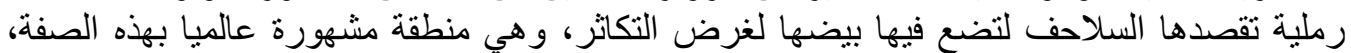

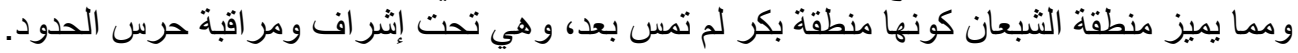

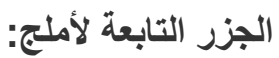

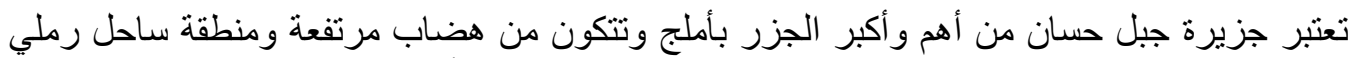

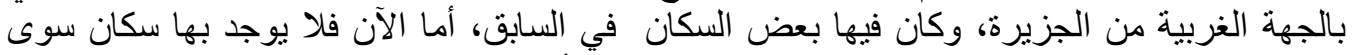

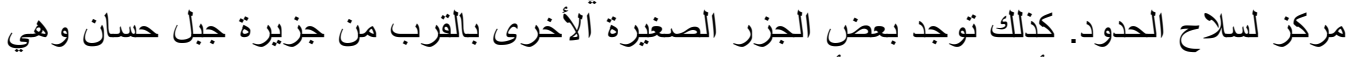

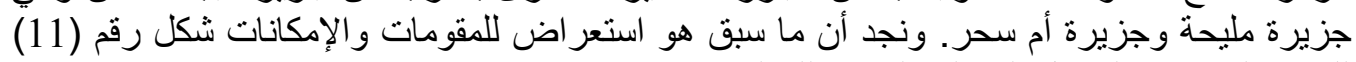
للتنمية السياحية بالساحل الثمالي الغربي للمثلكة.

2-5 محددات ومعوقات التنمية السياحية الإقليمية بالساحل الثمالي الغربي بالمملكة:

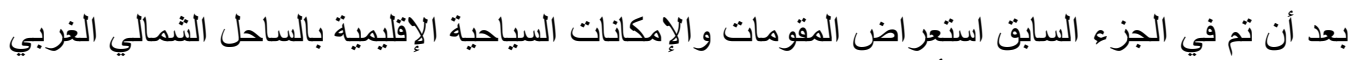

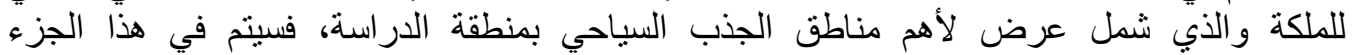

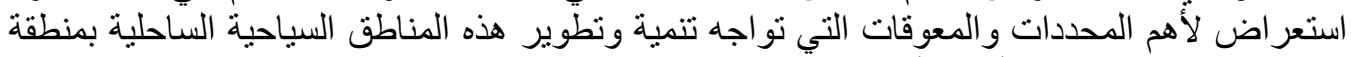

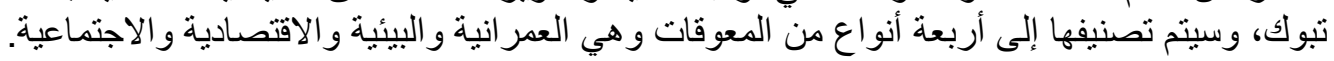
أولاً: المحددات والمعوقات العمرانية:

من خلال در اسات الوضع الر اهن نم استنتاج أهم المحددات والمعوقات المات المعات العمر انية كالتالي: شكل (12).

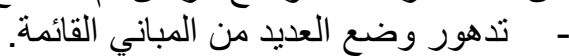

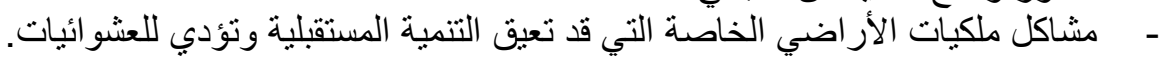

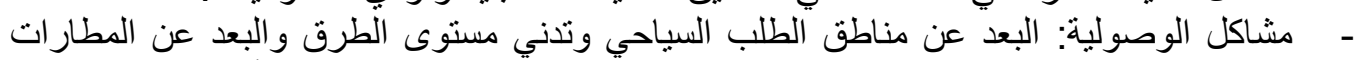

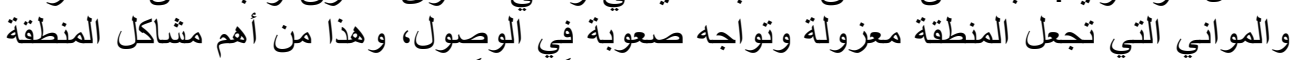

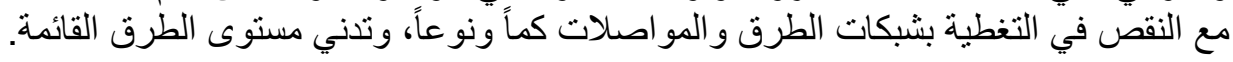




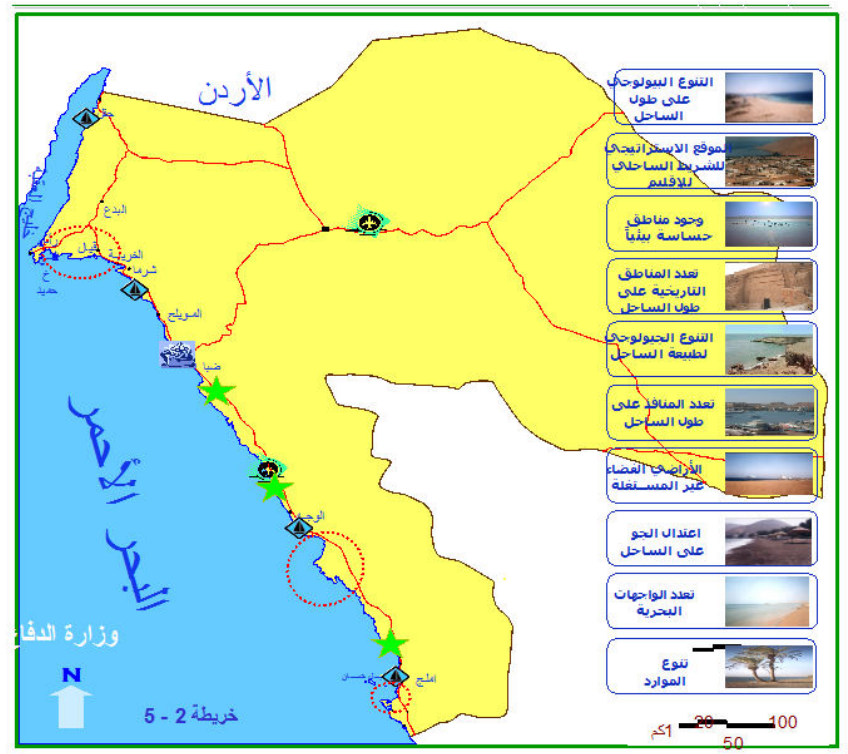

شكل (11) المقومات و الإمكانات للنتمية السياحية الإقليمية بالساحل الثمالي الغربي للملكة

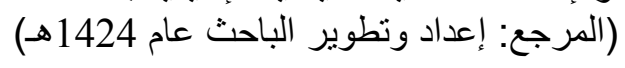

- - كثير من المناطق الساحلية لم تعد لها مخططات عمر انية شاملة وتفصيلية لتوزيع المناطق وتحديد

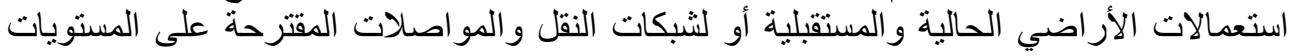

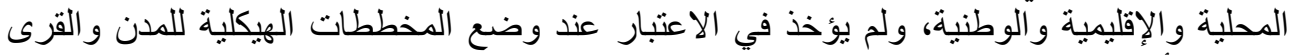
الساحلية أية اعتبار للتنمية السياحية الحالية و المستقلية الإلية.

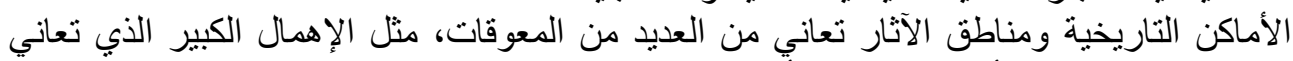

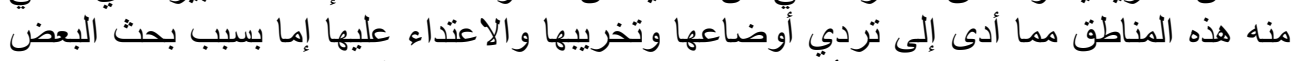

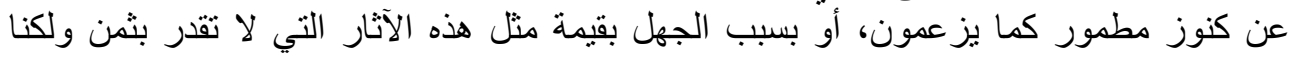

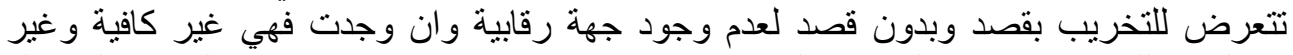

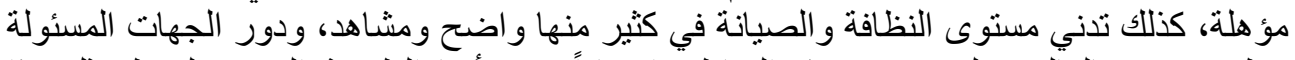

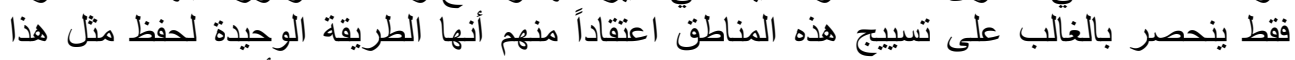

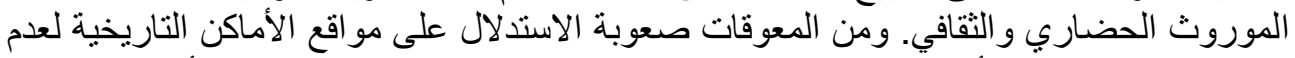

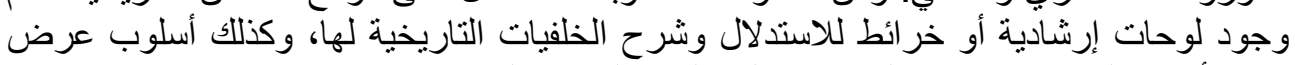

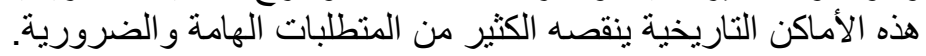

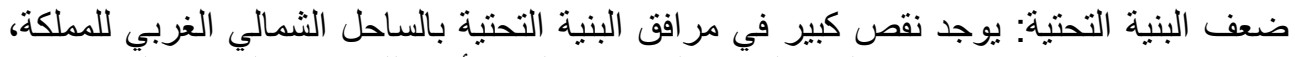

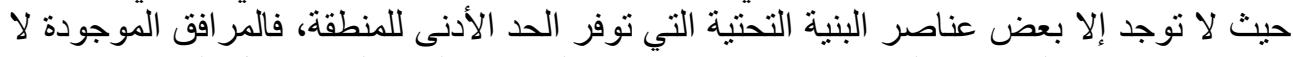

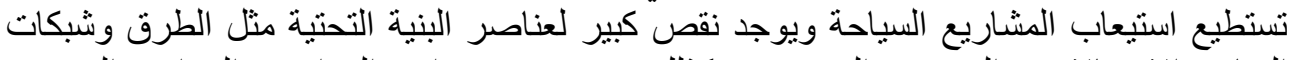

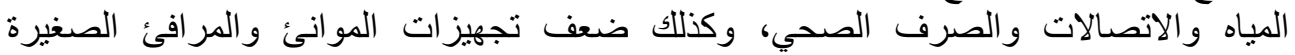

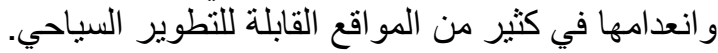

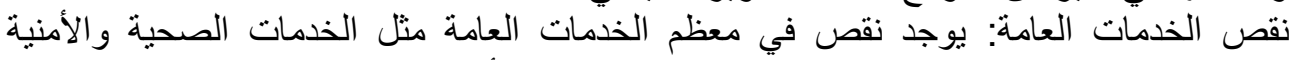

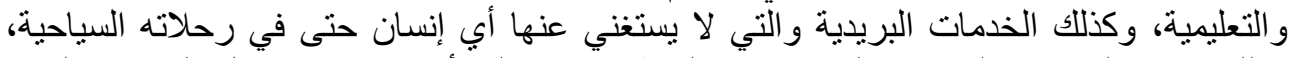

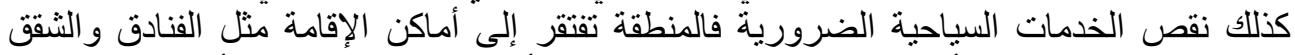

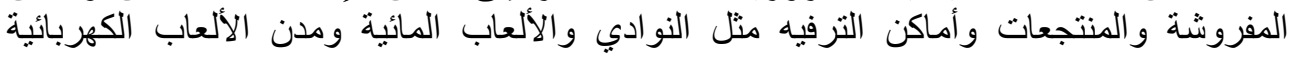

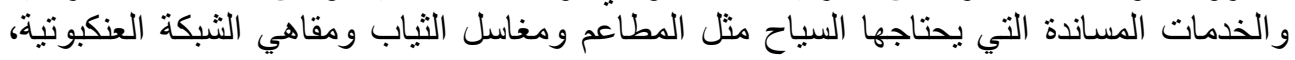


كذلك إهمال الصيانة حيث تعاني المرافق العامة والسواحل من إهمال الصيانة والنظافة مما أدى الهى

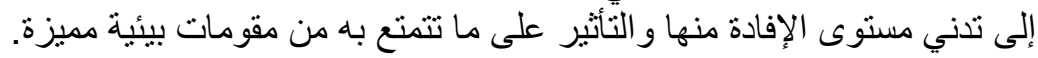

ثانياً: المحددات والمعوقات البيئية:

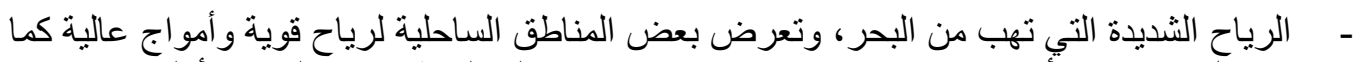

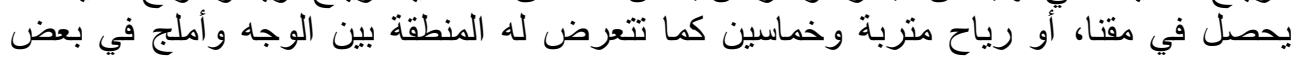

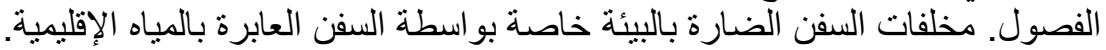

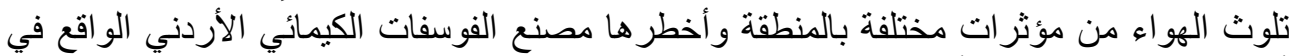

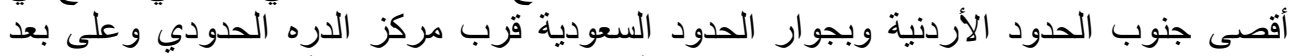

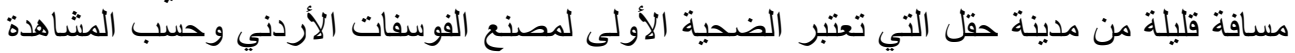

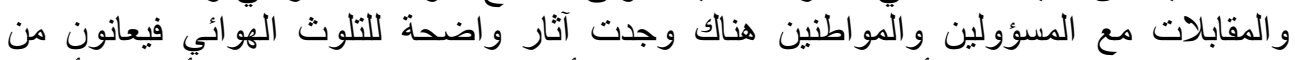

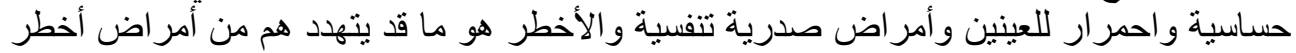

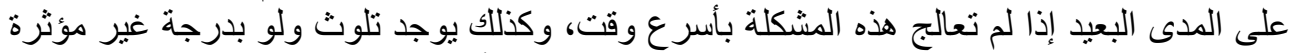

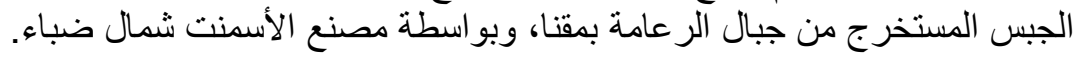

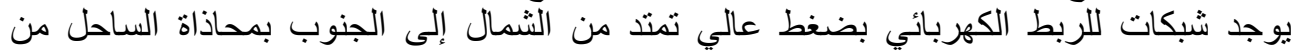

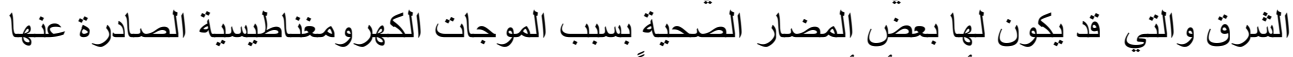

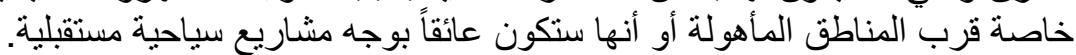

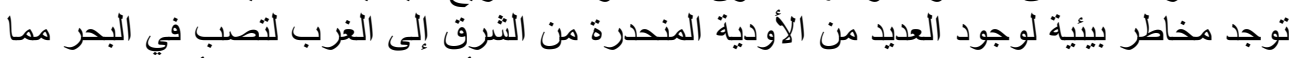

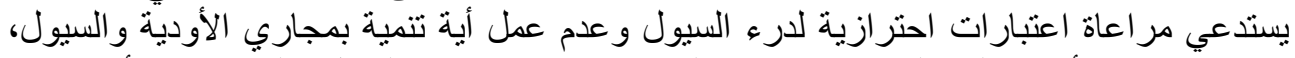

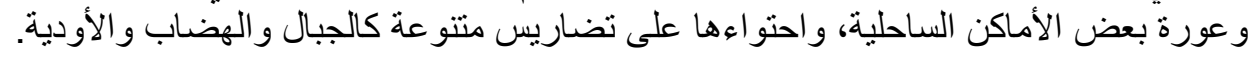

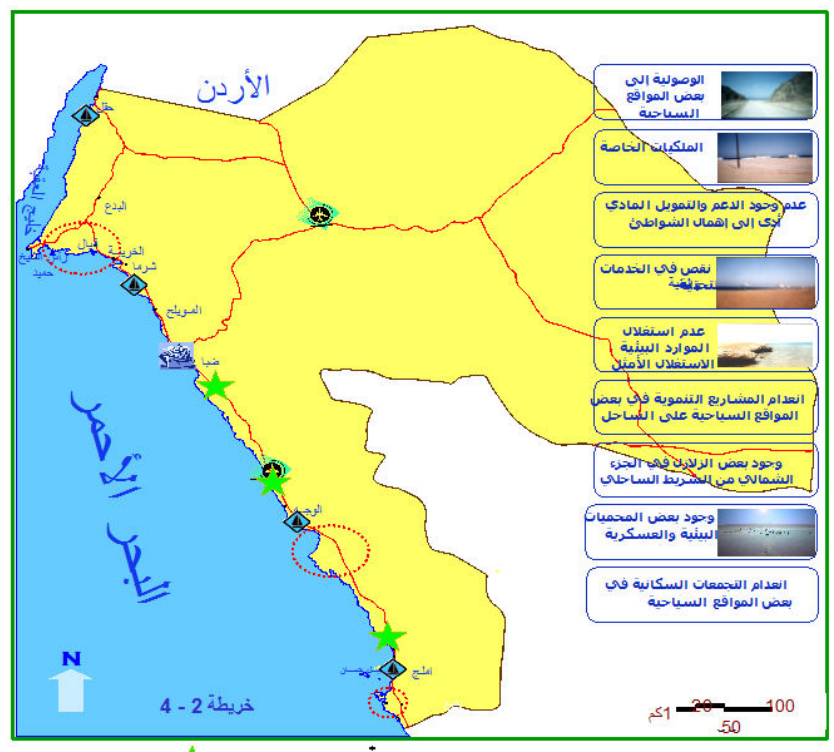

شكل رقم (12) محددات ومعوقات التنمية السياحية الإقليمية بالساحل الثمالي الغربي بالمملكة

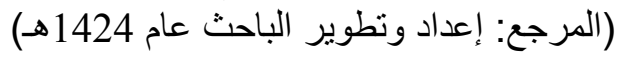


- ضعف القاعدة الاقتصادية بالمنطقة، فهي محصورة على المنتجات الزراعية وصبد الأسماك

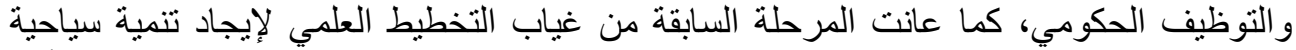

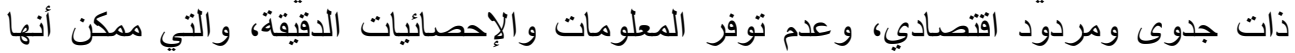

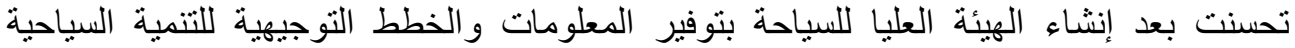
بمناطق المملكة ومنها منطقة تبوك وسواحلها، و عدم وجود استثمار ات في المشناريع السياحية

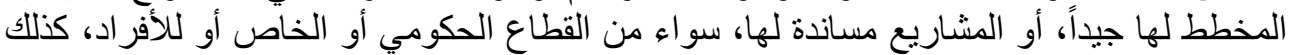

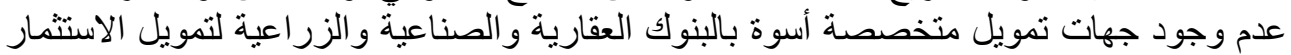
في القطاع السياحي أو المساهمة فيات فوديه.

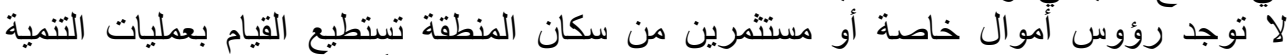

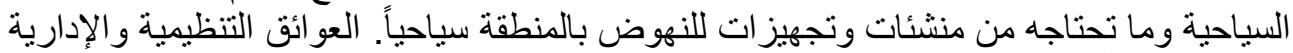

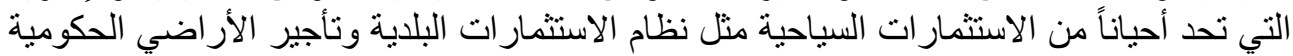

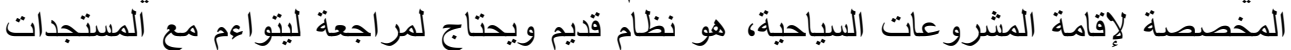

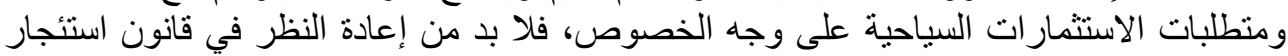

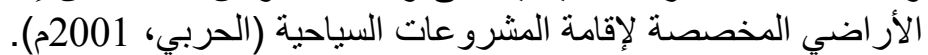

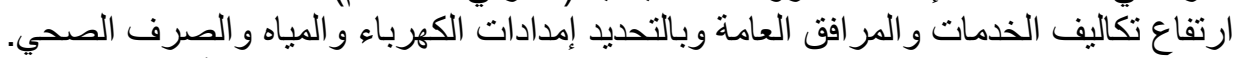

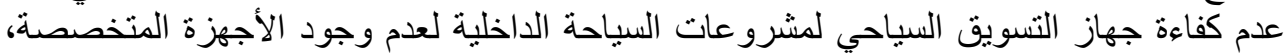

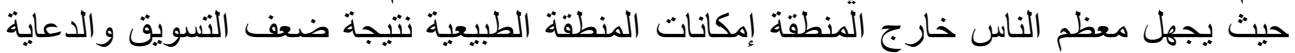

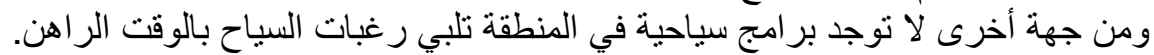

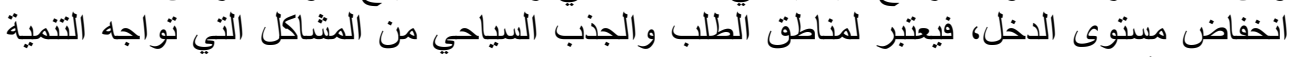

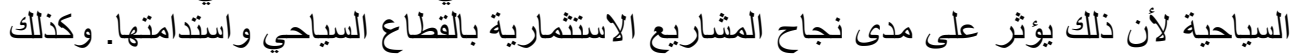

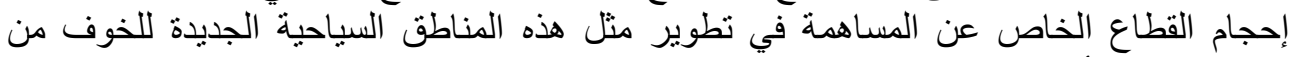

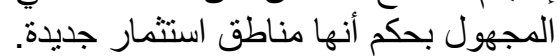

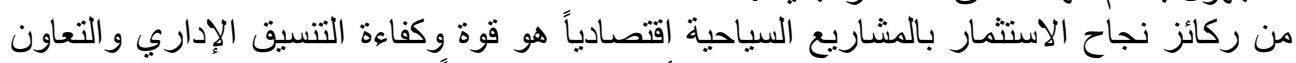
بين مختلف القطاعات ذات العلاقة و الذي يعتبر أمر المعار المقدا وصعباً.

رابعاً: المحددات والمعوقات الاجتماعية:

- ضعف الوعي السياحي لدى المجتمع المحلي بالمناطق السياحية، وهجرة الكثير من أهل المنطقة

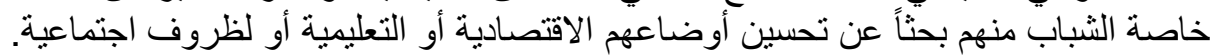

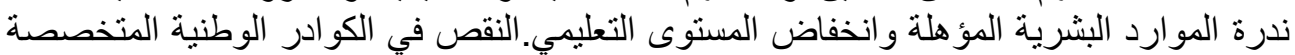

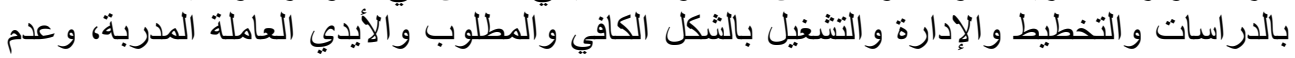
كفاءة الموجود منها بالمشاريع الإدارة السياحية.

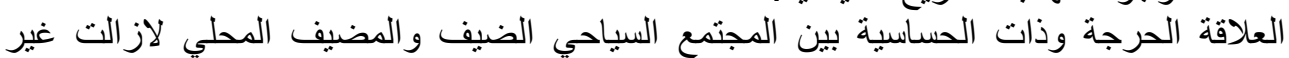

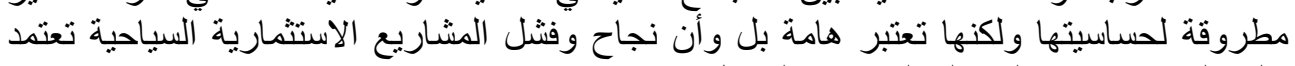

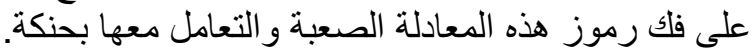

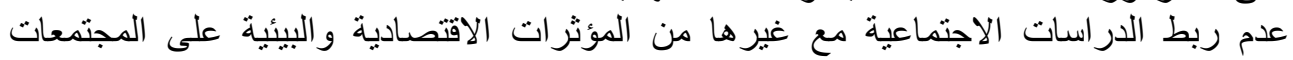

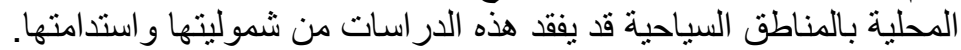

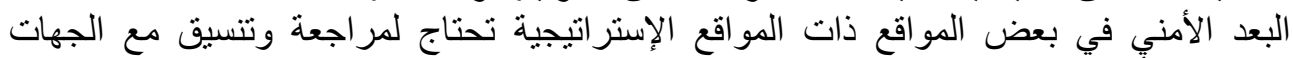

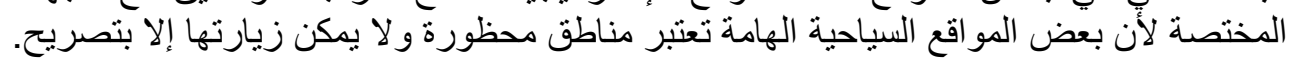




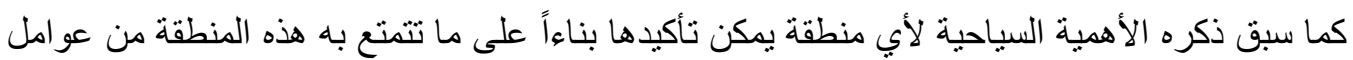

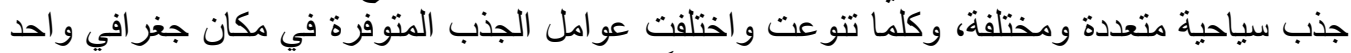

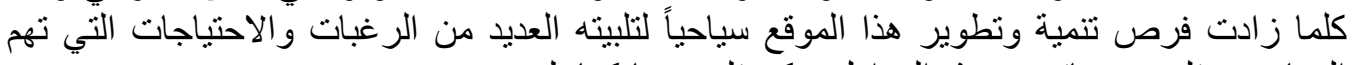

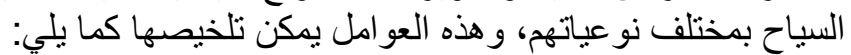

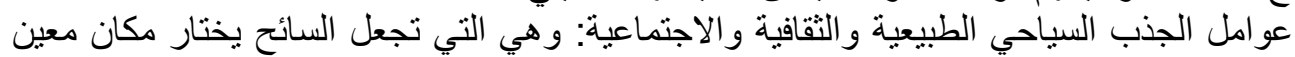

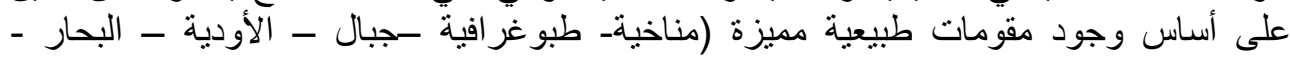

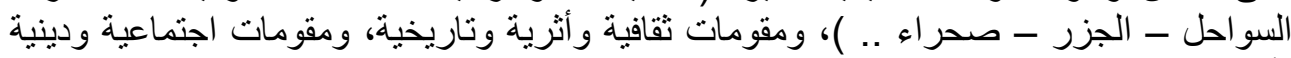

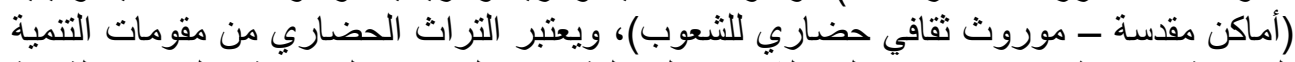

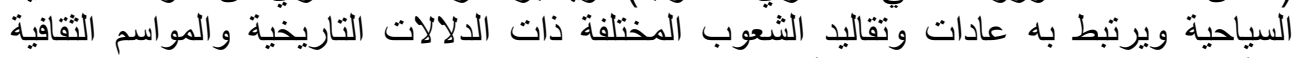

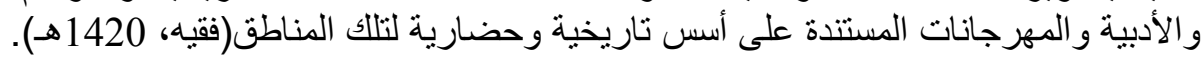

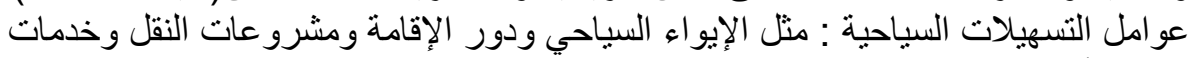
البنية الأساسية و التجارية.

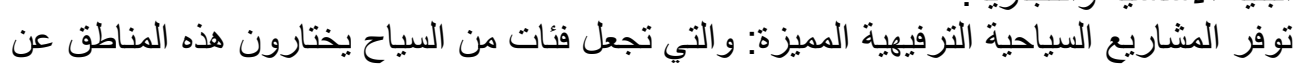

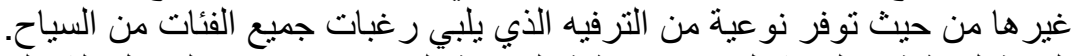

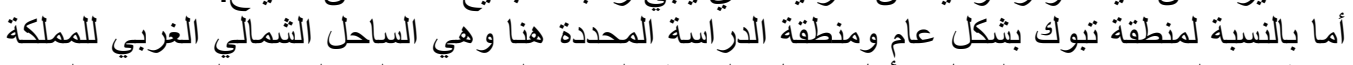

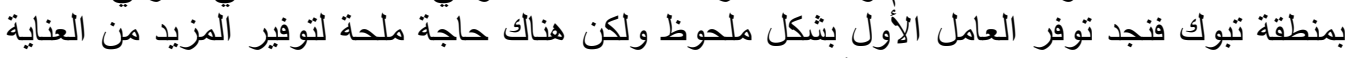

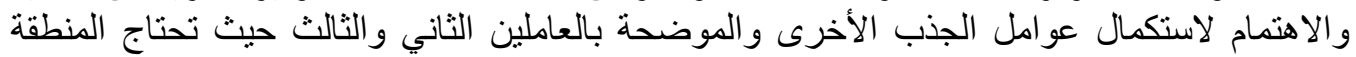

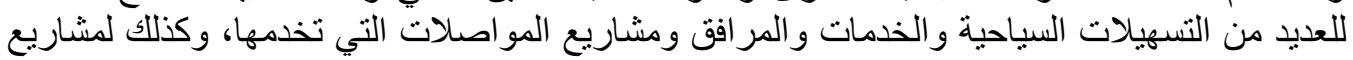
سياحية ترفيهية جاذبة للسياح.

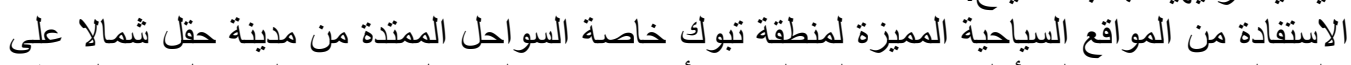

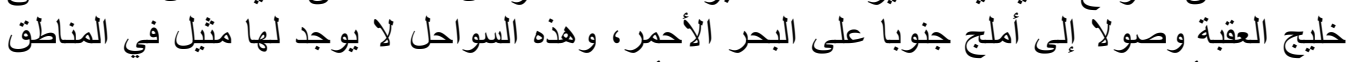

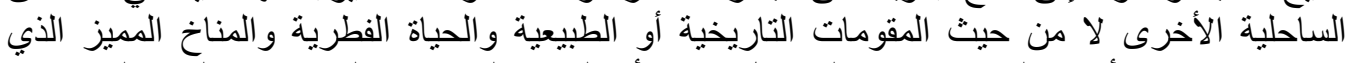

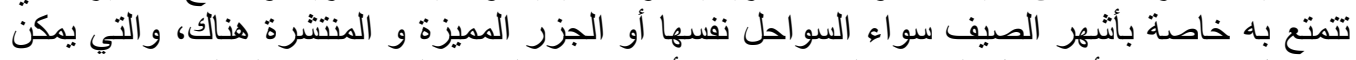
في حال استثمار ها أن تحول المنطقة إلى واحدة من أهم مناطق الجذب الجن السياحي في المملكة.

\section{6- روئة الباحث لتفعيل التنمية المستدامة بالمدن الساحلية بإقليم تبوك:}

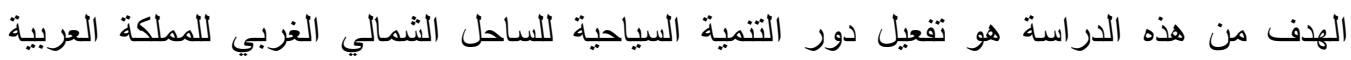

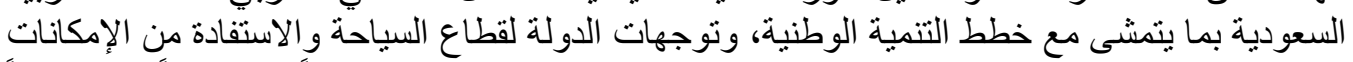

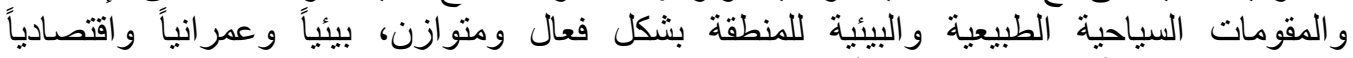

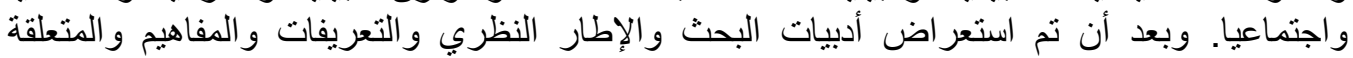

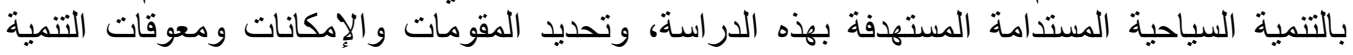

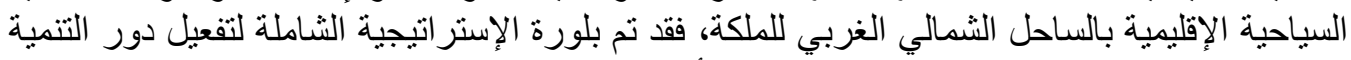

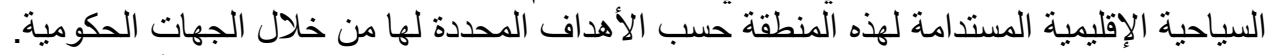

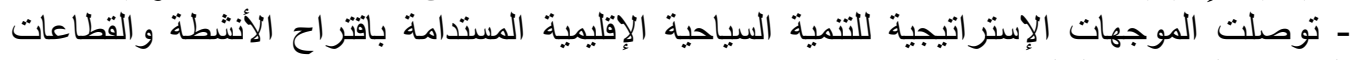

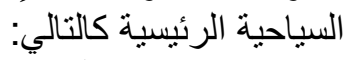

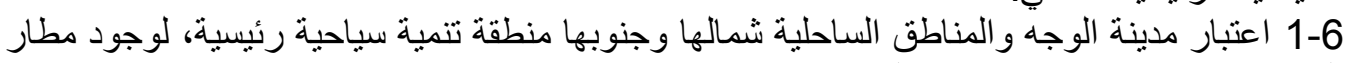

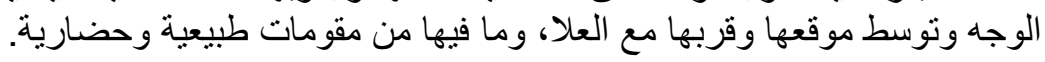

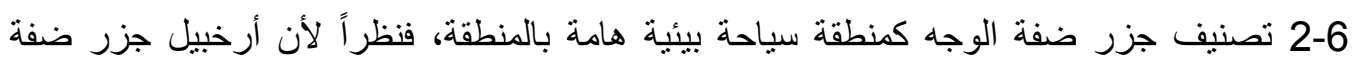

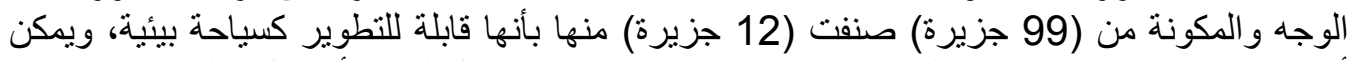

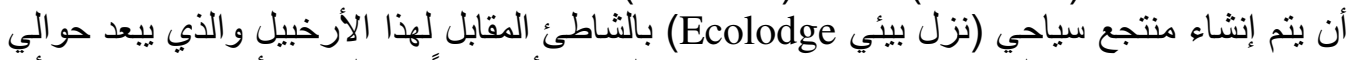

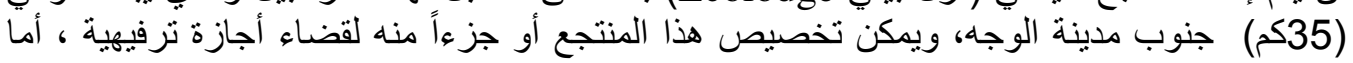


الجزر الحساسة بيئياً فسيتم زيارتها بشكل منظم ومدروس بقو ارب شر اعيه أو بمحركات بسيطة لاتحدث

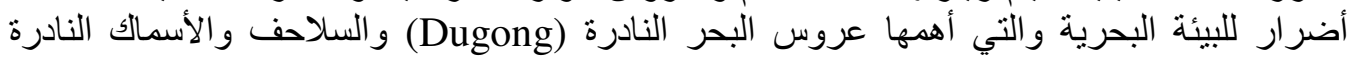

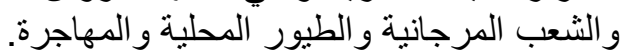
3-6 تخصيص مدينة حقل كمنطقة تنمية إقليمية رئيسية سياحية وسوق حرة، نظراً لموقعها

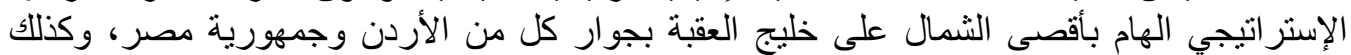

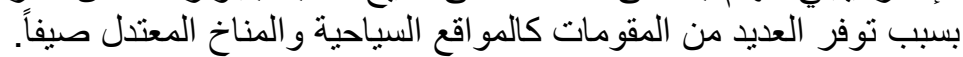

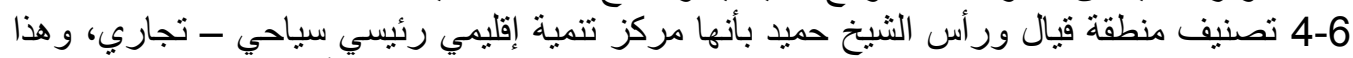

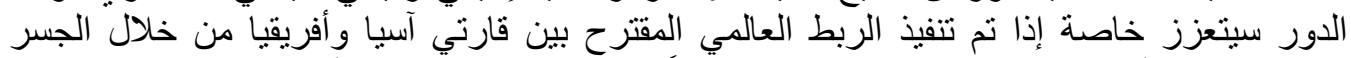

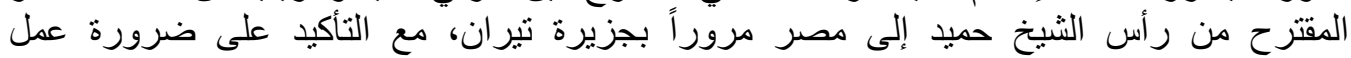

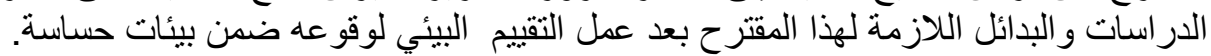

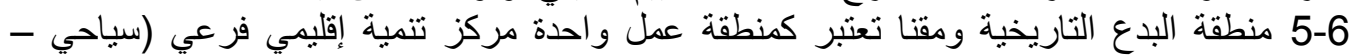

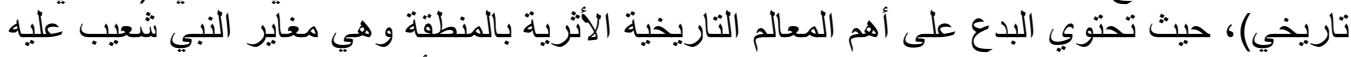

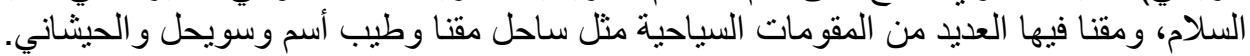

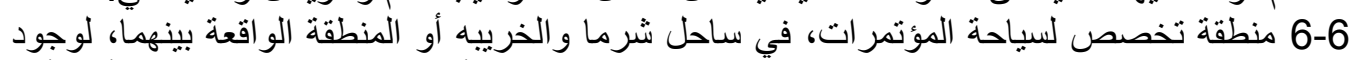

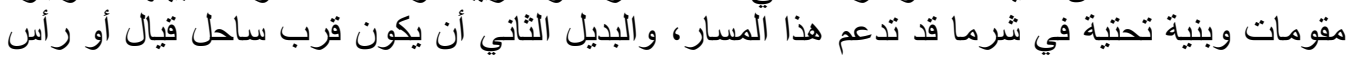

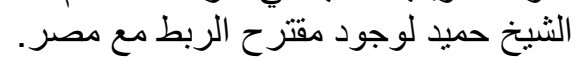

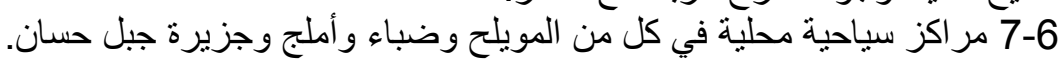

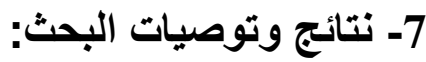

7-1 يوصي البحث بتكامل العمل والتنسيق بين الجهات المختصة مثل الهيئة العليا للسياحة ووزارة الثئون البلدية و القروية، و الهيئة الوطنية لحماية الحياة الفطرية، و إمارة منطقة تبوك وبلدية الحية منطقة تبوك الكية و المحافظات و البلديات الفرعية بساحل المنطقة للمحافظة على المقومات الماتية السياحية المميزة بها، و استثمار ها وفقاً للخطط و الاستر اتيجيات و البر امج المدروسة بما يضمن التطوير السياحي المستدام. 2-7 يوصي البحث بتبني استر اتيجية التنمية السياحية المستدامة للساحل الشمالي الغربي للئية للمملكة العربية

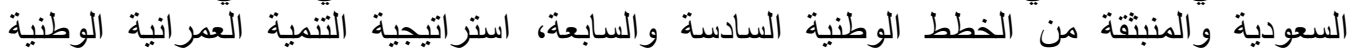
و استر اتيجية تتمية مناطق المملكة، وكذلك الخطة الوطنة الوطنية الهيكلية للسياحة.

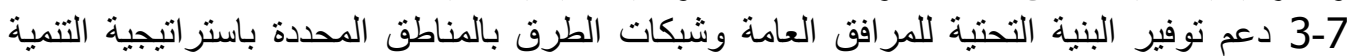

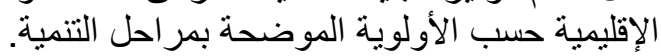

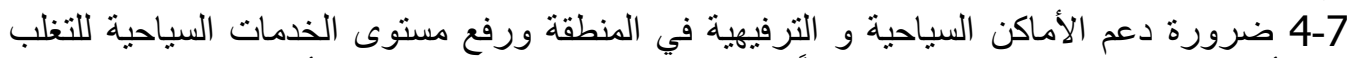

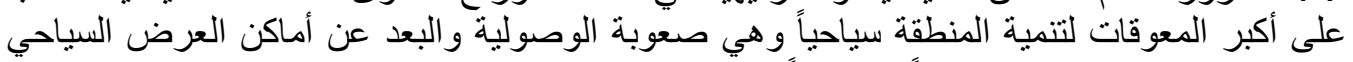

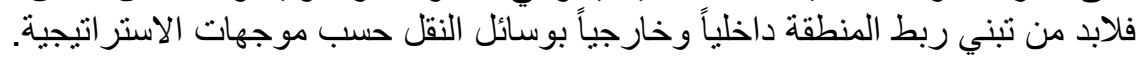

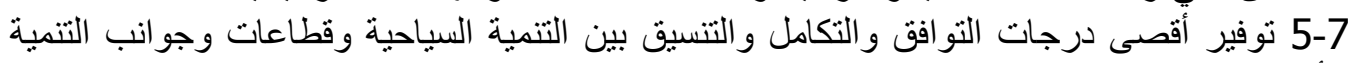

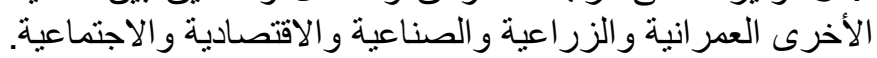

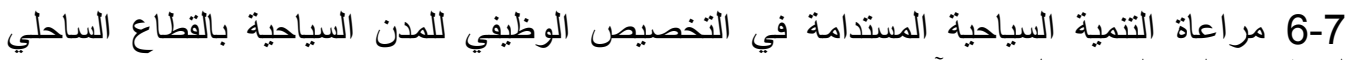
لمنطقة تبوك و التي تتمثل في الآتي:

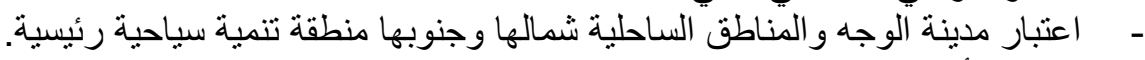

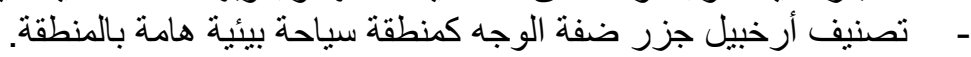

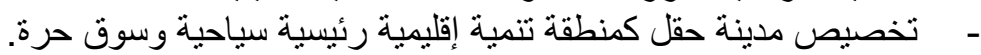

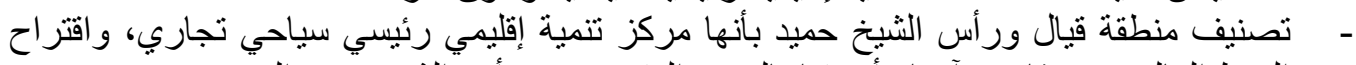

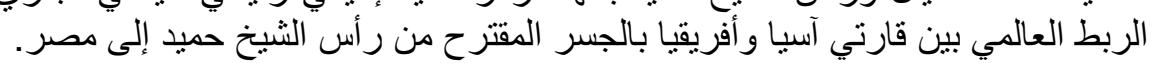


تخصيص منطقة لسياحة المؤتمرات، في ساحل شرما و الخريبه أو المنطقة الو اقعة بينهما، و البديل

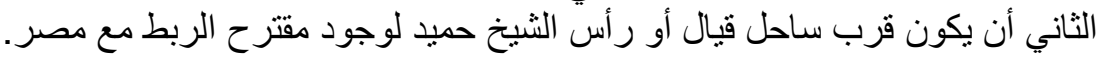

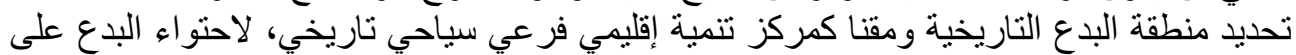

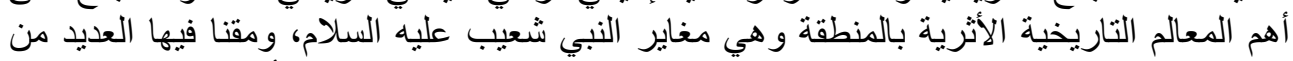

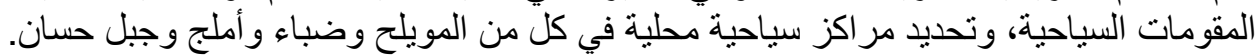

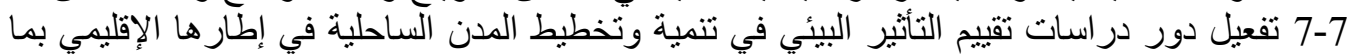

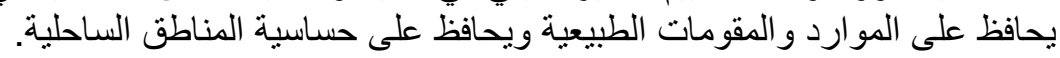

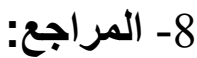

- الهيئة العليا للسياحة، المخطط الهيكلي لمناطق التنمية السياحية، المملكة السعودية عام (2001م).

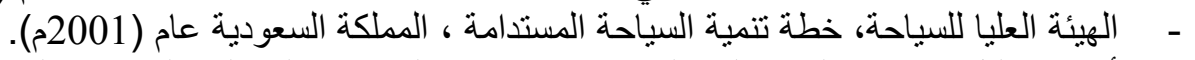

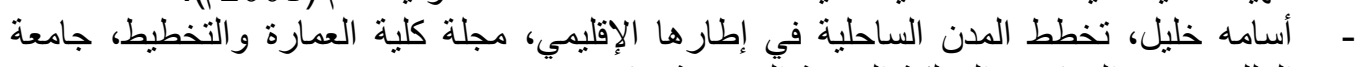

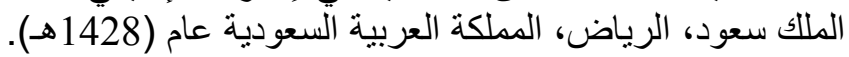

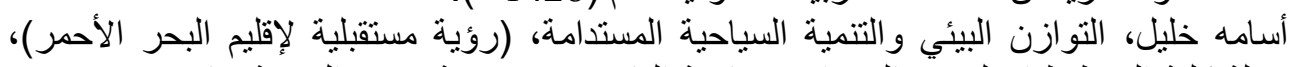

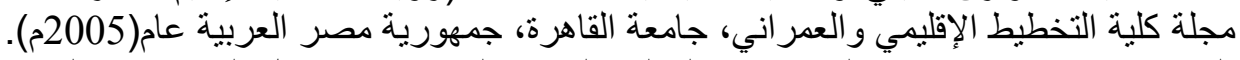

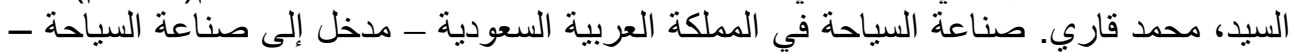
السياحة في محافظة الطائف - هوية السياحة في المئية المملكة العربية السعودية. اللجنة العلية العيا للتنشيط

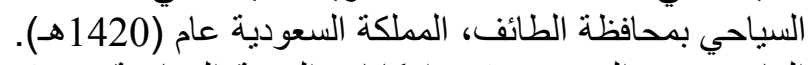
الغامدي، عبدالعزيز صقر ، إمكانات التتمية السياحية، بحث منشية الثنور في ندوة السياحة في المملكة

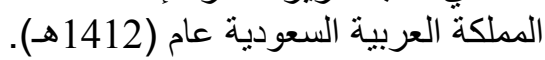
الغيص، سيف محمد، السياحة البيئية والتنوع البية البيولوجي في سواحل دول مجلس التعاون، المملكة العربية السعودية عام ( 1999م). فقيه، عبد الرحمن، السياحة بالمملكة السعودية. (لبعة مجلة النقل والمواصلات، العدد التاسع، المملكة العربية السعودية عام (1420هـ).

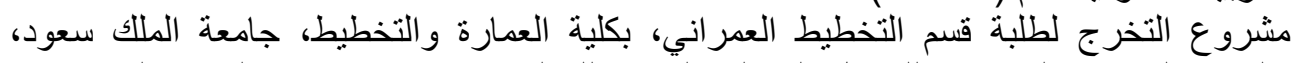

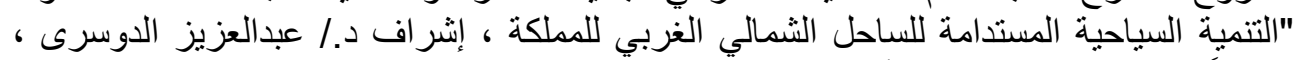

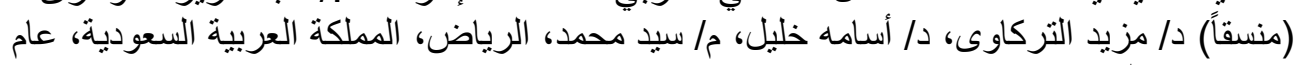

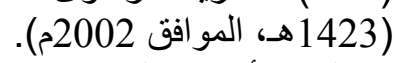
مصلحة الأرصاد الجوية وحماية البيئة، الكتاب الإحصائي السنوي، العدد السابع و الثناثون، المملكة

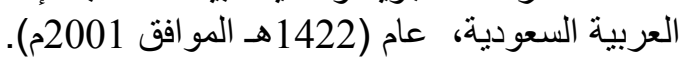
وزارة الثئون البلدية والقروية ، الإستراتيجية العمر انية الوطنية، المملكة العربية السعودية عام (1420) ـ وزارة الثئون البلدية والقروية، استراتيجيات تتمية المناطق، المملكة العربية السعودية، (ربيع الأول ، 1420 هـ). - عبدالعزيز الدوسرى، السياحة المستدامة، مجلة المهند،، العدد (1) المملكة العربية السعودية عام . (1422)

- Ba-Hammam, Omar (2003). Planning for A Successful Tourism: The Experience of Saudi Arabia. Journal of the Gulf and Arabian Peninsula Studies, 29(108): 49-85. 
- Dennison Nash, Tourism as Anthropological subject, in current Anthropology. The University of Chicago, (Oct. 1981, P. 461)

- http:www.world-tourism.org. (29 January).

- WTO (1999). Yearbook of Tourism Statistics. 51 st edn. Madrid: WTO.

- (W.T.O) World Taurism Organization, United Nations (2002). 